\title{
EFFICIENT LOCAL GOVERNMENT SERVICE PROVISION: THE ROLE OF PRIVATIZATION AND PUBLIC SECTOR UNIONS
}

\author{
Rhiannon Jerch \\ Matthew E. Kahn \\ Shanjun Li \\ Working Paper 22088 \\ http://www.nber.org/papers/w22088
}

\author{
NATIONAL BUREAU OF ECONOMIC RESEARCH \\ 1050 Massachusetts Avenue \\ Cambridge, MA 02138 \\ March 2016
}

We thank seminar participants at AEURUA in May 2015 and AERE Meetings in June 2015 for useful comments. We thank Kyle Barron and Jiwei Zhang for excellent research assistance. The views expressed herein are those of the authors and do not necessarily reflect the views of the National Bureau of Economic Research.

NBER working papers are circulated for discussion and comment purposes. They have not been peer-reviewed or been subject to the review by the NBER Board of Directors that accompanies official NBER publications.

(C) 2016 by Rhiannon Jerch, Matthew E. Kahn, and Shanjun Li. All rights reserved. Short sections of text, not to exceed two paragraphs, may be quoted without explicit permission provided that full credit, including $\odot$ notice, is given to the source. 
Efficient Local Government Service Provision: The Role of Privatization and Public Sector Unions

Rhiannon Jerch, Matthew E. Kahn, and Shanjun Li

NBER Working Paper No. 22088

March 2016

JEL No. J3,J45,R4,R5

\title{
ABSTRACT
}

Local governments spend roughly $\$ 1.6$ trillion per year to provide a variety of public services ranging from police and fire protection to public schools and public transit. However, we know little about public sector's productivity in delivering key services. To understand the productivity both over time and across space, we examine public bus service, which represents a standardized output for benchmarking the cost of local government service provision. There is significant dispersion across transit agencies in the operating cost per bus mile with the highest being more than three times as high as the lowest among top 20 largest cities by population. We estimate the cost savings from privatization and explore the political economy of why privatization rates are lower in high cost unionized areas. Our analysis finds that the full privatizaton could result in cost savings of $\$ 5.7$ billion in 2011 and that the gain in economic efficiency from more closely aligning bus fares with production costs would be worth at least half a billion dollars.

\author{
Rhiannon Jerch \\ Shanjun Li \\ $\mathrm{PhD}$ candidate \\ Cornell University \\ Dyson School of Applied Economics \\ 405 Warren Hall \\ and Management \\ Cornell University \\ Ithaca, NY 14853 \\ rlj78@ cornell.edu \\ s12448@cornell.edu \\ Matthew E. Kahn \\ Department of Economics \\ University of Southern California \\ KAP \\ Los Angeles, CA 90089 \\ and NBER \\ kahnme@usc.edu
}




\section{INTRODUCTION}

Over the last several decades, there have been large productivity gains in the private sector. For example, the U.S manufacturing sector's average annual productivity growth was $4.7 \%$ from 2000 to 2007 and it was 2.1\% from 2008 to $2015 .^{2}$ Similar productivity gains are unlikely to have occurred for the public sector because the sector is labor intensive in general and is likely to suffer from Baumol's Disease such that the cost of provision rises over time (Baumol 1967). For key local public services such as public schools, garbage collection, public transit services, fire protection and snow removal, we know little about local government productivity dynamics in delivering such services. Local public services represent a major expenditure category (\$1.6 trillion dollars were spent in 2012, amounting to 9.2\% of total GDP). State and local governments employed 19.3 million people in year 2012, over 13 percent of total employment.

In the absence of public sector productivity gains, rising costs for public services mean that local taxpayers face a higher tax burden. But part of these taxpayer expenditures are collected as higher wages by the public employees who earn more from public sector jobs than their next best alternative and are shielded from unemployment risk associated with private competitive labor markets. ${ }^{3}$ As of 2014, the median hourly wage paid by the Chicago Transit Agency to bus drivers was $\$ 32.25$ and the $25^{\text {th }}$ percentile was $\$ 24.2$ per hour. During a time of great concern about income inequality, public employment offers stable middle-class jobs for less educated and disadvantaged workers (Alesina, et. al 2000, Boustan and Margo 2009).

A challenge in studying public sector productivity trends arises because key indicators such as street safety or local school quality is both a function of who chooses to live in an area and the local government's ability to deliver quality services. Without a standardized metric of quality, it is quite challenging to evaluate the public sector's service efficiency at a point in time across cities or over time for the same city. In this paper, we argue that the operating cost of moving a bus one mile offers a standardized metric for ranking local government service efficiency. A distinctive feature of bus travel is its simple Leontief production function featuring three key inputs; a driver, a bus, and fuel. The bus

\footnotetext{
${ }^{2}$ http://www.bls.gov/lpc/prodybar.htm.

${ }^{3}$ Prior studies document how the public-sector wage premium is even higher when taxpayers respond inelastically to tax hikes. Brueckner and Neumark (2014) document how public employees are able to extract rents from local taxpayers in areas with attractive natural amenities. Public sector wages rise in absolute terms relative to private-sector wages in the presence of such amenities. This relationship is stronger for unionized public-sector workers. Diamond (2016) finds similar results in areas with inelastic housing supply.
} 
and the fuel needed to move the bus are traded on a national market (Kahn, Li and Nickelsburg 2015). Labor represents over $80 \%$ of the cost.

An inefficient transit agency can have a high operating cost per mile for two main reasons. It can overpay bus drivers and mechanics relative to their local opportunity cost or it can hire too many drivers and mechanics relative to the efficient level of employment. While a for-profit firm in a competitive industry would have sharp incentives to engage in cost minimization, non-profit public transit agencies have weaker incentives to do so as they face pressure from unions and local political leaders. ${ }^{4}$ We study the role of public sector unions as a key determinant of public transit operating cost differentials across space and time.

Privatization represents one strategy for checking local union power and mitigating Baumol's disease. A transit agency that privatizes a fraction of its bus miles is outsourcing a contract to private sector firms. This action (and even the threat of this action) could discipline public sector unions and is likely to enhance public sector efficiency (as measured by the cost per bus mile). We provide new estimates of the effect of privatization on the cost of government service provision. To identify the causal effect, we address the fact that privatization is an endogenous choice by employing a regression discontinuity (RD) design based on mayoral elections similar to Ferreira and Gyourko (2009). The political affiliation of city mayors can play an important role in public service provisions and the propensity for privatization increases when a Republican wins office.

The results from the RD design show that bus transit agencies experience substantial cost savings from privatizing: transit agencies can reduce per-mile operating costs by nearly 70 percent from privatizing the service provision, holding other factors constant. In addition to testing for the average effect of privatization, we also document that privatization has larger efficiency-improving effects for a city’s dominant transit agency and in areas with strong union power. Our findings are consistent with private enterprises operating at a lower cost and higher efficiency relative to their public counterparts. Private entities hire fewer laborers and engage in less “featherbedding” relative to public transit agencies.

\footnotetext{
${ }^{4}$ Winston (2010) provides a review of several institutionalized protections that inhibit labor production efficiencies. These include: powerful transit worker unions; Section 13(C) of the 1964 Federal Transit Act, which obligates a transit employer to pay extremely costly severance packages to divested employees; excessive administrative staffing in order to fulfill federal bureaucratic obligations; and large transit subsidies which discourage efficiency improvements. Excessive administrative staffing mandated by the subsidizing-government institutions are further documented by Lave (1991). Winston (2000) reviews how policymakers in charge of public entities tend to be responsive to political influences rather than market influences at the expense of efficiency.
} 
After estimating the effect of privatization on the cost of bus service provision, we use our estimates to conduct a welfare analysis. We quantify the deadweight loss from public provision of highcost services and provide new estimates of the cost of transferring income to the public sector unions relative to the deadweight loss. Larger cities with strong union power experience substantial losses in consumer surplus from costly public transit. Our estimates suggest that fully privatizing all bus transit would produce cost savings of approximately $\$ 5.7$ billion, or 30\% of total US bus transit operating expenses. The increased usage of public transit from the corresponding cost reduction would lead to a gain in social welfare of at last $\$ 524$ million.

The paper is organized as follows. Sections 2 describes the relationship between labor unions and transit operating costs across the U.S. Sections 3 and 4 present our theoretical model of transit service provision and our empirical identification strategy, respectively. Section 5 describes the context and the data while Section 6 discusses our empirical results. We provide estimates of social welfare losses in Section 7, and Section 8 concludes.

\section{Spatial and Temporal Variation in Operating Costs of Bus Transit}

The cost of operating a public bus varies greatly across U.S. cities. Table 1 compares the operating cost of public costs (in cost per mile) across the twenty largest urbanized areas in the U.S. in 2012. The cost per mile is calculated as total annual operating costs divided by total annual vehicle miles traveled (VMT). (See Appendix 1 for details on the line items of operating costs.) These values range from \$5.57 per mile in Tampa, Florida, to \$18.67 in New York City, New York. Much of this variation is driven by variation in wages paid to drivers and mechanics. In particular, transit agencies operating in states with strong union power have higher costs per mile. Figure 1 compares the average operating costs per mile over time for transit agencies in weak bargaining states versus strong bargaining states. ${ }^{5}$ Costs per mile are consistently higher in strong bargaining states. Table 2 illustrates how the $90^{\text {th }}$

\footnotetext{
${ }^{5}$ State bargaining rights data are sourced from R.G. Valletta and R.B. Freeman (1988), "The NBER Public Sector Collective Bargaining Law Data Set." Appendix B. The level of a state's collective bargaining provision are coded as values ranging from 0 (no state laws relevant to bargaining rights) to 6 (state law dictates employer is obligated to negotiate and come to written agreement with unionized public employee). We classify states with strong bargaining rights laws are those where legislative mandate either implicitly or explicitly dictates public employers and union employees must come to an agreement on contract negotiations (values 5 and 6). States with weak bargaining rights laws either prohibit collective bargaining all together, or do not mandate that the public employer bargain with unions (values 4 or less). Courts have typically interpreted an absence of provision for collective bargaining (value of 0 ) as prohibiting collective bargaining (Freeman and Valletta (1988)), thus we include states classified as level 0 as weak bargaining rights states.
} 
percentile of costs per mile in weak bargaining states is consistently lower than the $50^{\text {th }}$ percentile among strong bargaining states.

In contrast, privatization shares are consistently lower in strong bargaining states. A transit agency's privatization share is the ratio of privatized vehicle miles traveled to total vehicle miles traveled. Table 1 illustrates how the average privatization share for the twenty largest urbanized areas is negatively correlated with cost per mile. San Diego, CA, for example, was 63\% privatized as of 2012, and had a cost per mile of \$7.09. San Jose, CA on the other hand, which has a similar cost-of-living index, had an average cost per mile nearly 56\% higher than that of San Diego at \$12.63, and this agency’s bus transit is operated almost completely in-house (the privatization share is 1.3\%).

Figure 2 displays the growth in privatization shares, comparing strong and weak bargaining states. Strong bargaining rights states have lower privatization shares across the board. Taken together, Figures 1 and 2 illustrate a paradox whereby transit agencies with higher costs are less likely to privatize. Union power appears to simultaneously increase transit agency costs and limit the degree to which the transit agency can outsource their operations.

For some major cities including Boston, Chicago, Denver, and Houston, we are able to access their administrative salary databases listing their universe of bus operators. These data provide the count of drivers and their salary or hourly wage. In Table 3 we report the empirical distributions of current hourly wages for these major transit agencies, as well as descriptive summary statistics on employee utilization, union presence and mean home prices in each city. Boston and Chicago have stronger union presence relative to Houston or Denver because the share of unionized workers in these urbanized areas are higher and because Massachusetts and Illinois are non-right-to-work states. Note that cities with a stronger union presence have more employees per VMT and higher wages paid to transit agency employees. The employees earning the $25^{\text {th }}$ percentile wage in Boston and Chicago earn more than the $75^{\text {th }}$ percentile employees in Houston or Denver. It is unlikely that housing costs entirely explain this divergence in pay. Chicago has lower average home prices than Denver.

\section{A Model of Transit Service Provision and Privatization}

Each transit agency is required to forecast aggregate demand for its services and then to prepare to supply these miles by purchasing buses, fuel and hiring drivers and mechanics. We model the manager's decision as choosing operating inputs to minimize the total operating cost conditional on 
capital and fleet inputs. Managerial decisions on capital and fleet procurement are less frequent relative to operating input decisions of labor, maintenance, and fuel. While Li, Kahn and Nickelsburg (2015) study the durable bus investment decision and its implications on energy efficiency for transit agencies, we focus on the labor input decisions and productivity under the influence of labor union rules.

\subsection{Optimization and Input Decisions}

A transit agency provides service (i.e., vehicle miles) using three essential inputs: the physical input (bus), fuel, and labor. The production function is Leontief:

$$
Q=\min \left\{g_{k}\left(K, \eta^{k}\right), g_{l}\left(L, \eta^{l}\right) g_{f}\left(F, \eta^{f}\right)\right\},
$$

where $Q$ denotes the amount of bus service demanded, $K$ the number of buses, $L$ labor input and $F$ fuel input. $\eta^{k}, \eta^{f}$ and $\eta^{l}$ are productivity shocks (including both observed and unobserved to researchers) that affect how efficiently these inputs produce the service. The function $g_{k}($.$) translates buses into$ effective capital (i.e., buses in full operation). The function $g_{l}($.$) translates labor inputs (e.g., number of$ full-time equivalent employees) into effective labor (e.g., non-idle). The function $g_{f}($.$) translates the fuel$ input into energy used to propel the bus and is affected by bus fuel economy, engine type and unobserved shocks such as driving conditions.

The transit managers first decide the physical input $K$ through capital investment to meet the (expected) local demand for bus services. Then they decide the fuel and labor inputs to operate the buses while observing shocks denoted by $\eta$. We focus on the operation stage where transit agency managers choose inputs to minimize the operating costs while meeting the demand of the service area.

The static optimization problem can be defined as:

$$
\begin{gathered}
\min _{\{E, L\}} W * L+P * F \\
\text { s.t. } \min \left\{g_{k}\left(K, \eta^{k}\right), g_{l}\left(L, \eta^{l}\right), g_{f}\left(F, \eta^{f}\right)\right\}=\bar{Q},
\end{gathered}
$$

where $W$ is wage and $P$ is fuel price. We assume the following functional forms for $g_{l}\left(L, \eta^{l}\right)$ and $g_{f}\left(F, \eta^{f}\right)$ :

$$
g_{l}\left(L, \eta^{l}\right)=L * \exp \left(\eta^{L}\right)
$$




$$
g_{f}\left(F, \eta^{f}\right)=F * \exp \left(\eta^{f}\right)
$$

The optimal fuel and labor inputs and the total cost function can be written as:

$$
\begin{aligned}
& L^{*}=\bar{Q} / \exp \left(\eta^{L}\right), \\
& F^{*}=\bar{Q} / \exp \left(\eta^{f}\right) .
\end{aligned}
$$

The total cost function can be expressed as:

$$
T C^{*}=\bar{Q}\left[W / \exp \left(\eta^{L}\right)+P / \exp \left(\eta^{f}\right)\right]
$$

Conditional on the capital investment decision (i.e. the bus type), fuel productivity shocks, $\eta^{f}$, are mainly dependent upon congestion and other local driving conditions. These forces are arguably out of the control of transit agency managers and are treated as exogenous to their cost minimization decision. ${ }^{6}$ Labor productivity shocks $\left(\eta^{L}\right)$, on the other hand, are dependent upon local labor and political conditions which the transit agency manager may be able to counteract through the use of private contractors. Labor input decisions are the major determinant of a transit agency's cost minimizing problem.

Wages for bus transit workers depend upon local prevailing wages, as well as public sector union strength. There are two main avenues through which unions increase the costs of transit service provisions. First, the majority of transit union labor contracts place substantial limits on use of part-time workers. Contracts either stipulate minimum eight-hour shifts, or require a minimum ratio of all runs be "straight runs" as opposed to "split runs". 7 These rules work in direct opposition to the heavily peaked demand of transit service. During midday lulls, workers may be paid even when they are not driving. On the other hand, if a driver works more than an eight-hour shift - extending between morning and evening peak demand - the additional hours are compensated as over-time pay. ${ }^{8}$ If managers are able to negotiate for part-time employees, they must pay concessions in the form of wages or benefits that often outweigh gains from lower labor utilization (Giuliano \& Lave 1989). By limiting the use of part-time labor, public sector union strength enters into the $\eta^{L}$ term in equation (1), and inhibit the translation of employees into

\footnotetext{
${ }^{6}$ The transit agency manager may decide to alter bus routes in order to reduce fuel costs, but must maintain service at the desired quantity, $\bar{Q}$.

7 "Split runs" partition driver duties into multiple pieces for a given route, as opposed to a "straight run” where a driver works a continuous eight-hour day. (MacKechnie (2015); Bloomberg 2013).

${ }^{8}$ In 2010, over time costs paid to New York City's MTA employees amounted to 13 percent of payroll, or the equivalent of employing 7,000 additional full-time workers (Bloomberg 2013).
} 
fully-utilized, effective labor. The second avenue through which unions increase the cost of service provision is pensions and fringe benefits. The costs of union workers’ pensions can amount to 50 percent of their direct wage bill (Black 1991; DiSalvo 2010). Higher unit costs serve to increase $W$ in equation (4).

A unionized transit agency is likely to pay a higher wage per hour and to have more drivers and mechanics on payroll than would be predicted by the cost-minimizing decision under competitive labor markets. The net effect is a higher average cost per mile of bus service. Figure 1 illustrates the positive correlation between average unit cost of bus service and state union strength. Non-right-to-work states exhibit consistently higher unit cost over time relative to right-to-work states. Figure 2 illustrates how privatization of bus transit is consistently higher among right-to-work states, where union presence has a lower impact on state bargaining laws. ${ }^{9}$

Figure 3 depicts the optimization problem of transit agency managers discussed above. The technology is represented by the isoquant curve for each level of bus service provision. The vertex point is the cost minimizing input choice and the line passing through that point is the isocost curve. Here we assume that the input markets are competitive. For example, the labor market is free of union influence and the wage rate determined by the competitive labor market. However, the realized total cost for the same level of output could be higher due to two potential reasons: inefficient input use and higher input prices. The upper isocost curve in Figure 3 illustrates both channels: it uses more labor for the same level of bus service while the labor cost is higher (a steeper slope).

Now that we have modeled the cost of producing bus miles under alternative local rules, we introduce the privatization decision, which is one strategy transit agency managers can use to counteract union influence and cut costs.

\subsection{The Privatization Decision}

The ultimate goal of privatization by transit agencies is to reduce costs especially in the face of a tight budget. Many cities use privatization as a way to reduce costs for other types of service provisions. ${ }^{10}$ Local and state level economics conditions affect the revenue base that provides the

\footnotetext{
${ }^{9}$ In a study on the impacts of state legal environment on county-level privatization of public services, Lopez-de-Silanes, Shleifer, and Vishny (1997) find prohibition on public employee political activity and low unionization encourage privatization of public services.

${ }^{10}$ Levin and Tadelis (2010) examine the privatization decision of city services by examining the probability of privatizing city services as a function of service- and city- specific characteristics. They conclude that services for which it is harder to measure and monitor performance are less likely to be privatized. In their empirical work, they find that cities which are
} 
majority of the operating funding for bus services. Therefore, sluggish economic growth could provide the impetus for transit agencies to explore the cost-cutting options such as privatization, especially in areas more vulnerable to macroeconomic fluctuations such as a weak local housing market. A strong public sector presence can increase the unit cost of public service provision, but also make it harder to privatize. The opponents of privatization often argue that the public sector provides steady, well-paying jobs for middle class minorities and that the service from private contractors are less safe, less reliable and, ultimately, more expensive. ${ }^{11}$

The decision to privatize transit operations originates either with agency management or with a governing body of the agency, such as a county board of supervisors. The agency seeks bids from multiple private competitors. Contract lengths generally span one to three years, after which the transit agency management again seeks bids from competitors (Iseki et al. 2005). Most often, the transit agency pays the private firm a negotiated fixed rate per unit of service delivered.

The privatization of certain service routes includes a wide range of contractual arrangement between the transit agency and private contractors. Contract specifications can range from managerial or maintenance assistance alone, to full "turn-key” relationships, where the contractor performs all essential roles including financial management, procurement, marketing and scheduling. In most instances, private firms are contracted to manage personnel who operate and maintain the buses for a sub-set of service routes offered by the public transit agency. In some instances, private firms are contracted to operate all routes offered by the public agency. The private firm is in charge of hiring, compensating, and scheduling employees, as well as negotiating labor contracts with union representatives. Transit agencies retain control over key policy decisions, including service levels, fares, annual operating plans, and contractual compliance. The transit agency is also in charge of budgeting and financing operations, and maintains ownership of all equipment, vehicles, and facilities.

Most private contractors of bus transit are national or multinational firms. ${ }^{12}$ While market forces incentivize private firms to keep costs at competitive levels, private firms further benefit from

\footnotetext{
larger, newer, or in the western part of the U.S. are more likely to contract out public services to private providers. They also find a negative correlation between city expenditure per capita and privatization of public service.

11 “Public-Sector Jobs Vanish, Hitting Blacks Hard” by Larry Hanley, President, Amalgamated Transit Union International, Washington, http://www.nytimes.com/2015/06/02/opinion/public-sector-job-decline.html.

12 The three largest private contracting companies, Veolia, First Transit, and MV Transit collectively accounted for 65 percent of all US public bus transit contracts in 2013 (NTD.gov). Veolia is a French company that operates worldwide. MV Transit is a US-based company with international operations. First Transit is a US-based company that operates in the US and Canada.
} 
economies of scale in ways that public providers cannot. Accumulated experience garnered from managing several transit agencies at once and negotiating with labor unions enable private firms to employ labor and other operating inputs in a more cost-efficient way than their public counterparts. For example, the demand for bus service is highly peaked in the morning and evening commute hours. Private contractors can hire part-time workers to meet the demand during peak hours while public transit agencies have more limited ability to negotiate for part-time labor use in the face of public sector unions.

\section{The Effects of Privatization and Unions on the Cost of Service Provision}

Whether and to what extent privatization reduces the cost of public service provision are contentious issues. Using panel data on hundreds of transit agencies’ annual operating costs, we seek to understand why agencies differ with respect to their cost of service provision and what role privatization plays in lowering such costs. Since privatization is a choice, we must explicitly model the determinants of this endogenous variable.

\subsection{The Empirical Specification}

To examine the effect of privatization and other factors such as public sector unions on efficiency and input costs, we specify the productivity shocks to labor $\left(\eta^{l}\right)$ in equation (2) as a function of privatization and other factors:

$$
\eta^{l}=-d \gamma-x \beta-\varepsilon
$$

where $d$ is a variable characterizing the level of privatization from 0 (no privatization) to 1 (full privatization of all bus service). $x$ are other observed covariates that affect productivity and $\varepsilon$ are unobserved to researchers.

With the optimal labor inputs and productivity shocks from equations (2) and (5), we can write the unit labor cost, $l$, as the following:

$$
l=L^{*} * W / \bar{Q}=W / \exp \left(\eta^{l}\right)=W / \exp (-d \gamma-x \beta-\varepsilon) .
$$

Performing a log transformation on the input cost equation yields:

$$
\ln (l)=\ln (W)+d \gamma+x \beta+\varepsilon
$$


Our measure of $W$ is the average weekly wage earned by a full-time worker without any college education in the urbanized area. The earnings data are sourced from the BLS Current Population Survey. We use the urbanized-area average wage for two reasons. First, we do not observe wages (and benefits) that transit agencies pay their employees. Second, the actual wages paid to transit employees are an endogenous choice made by the agency. The BLS-sourced wage data provide a measure of the competitive market wage for a low skill employee in a given urbanized area and thus are unlikely to be correlated with transit agency-specific costs. Therefore, we include a coefficient for $\ln (W)$ in the regression. Denote a transit agency by $i$ and time by $t$, we rewrite equation (6) as:

$$
\ln \left(l_{i t}\right)=\alpha \ln \left(W_{i t}\right)+d_{i t} \gamma+x_{i t} \beta+\tau_{t}+\eta_{s}+\varepsilon_{i t} .
$$

Equation (7) provides the basis for our empirical analysis. We include variables in $x$ such as union strength and collective bargaining to control for the difference between the compensation of transit workers (reflected in the labor cost data) and the wage variable used in our regression (the average wage of all workers without college degree). We also include a set of time fixed effects $\tau_{t}$ to control for common time trends across transit agencies and state fixed effects $\eta_{s}$ to control for timeinvariant shocks within a state.

\subsection{Identifying the Effect of Privatization}

The decision for a transit agency to privatize some (or all) of their operations is likely to be influenced by local characteristics as well as expectations about future operations and service demand, each of which may not be fully captured by $x_{i t}$ and may affect agency unit costs, $l_{i t}$. The inability to control for such factors will render $\varepsilon_{i t}$ to be correlated with the treatment, $d_{i t}$, which will bias estimates of $\gamma$. To address this identification challenge, we employ a regression discontinuity design by using data on mayoral election and partisanship of the elected mayors. ${ }^{13}$ Partisanship impacts public spending and the propensity to privatize public services (Gerber and Hopkins, 2011; Richmond, 2001). ${ }^{14}$ All else

\footnotetext{
${ }^{13}$ In Appendix 2, we also provide results based on three alternative strategies as robustness checks: the first one uses as the instrument variable a Bartik measure of state employment growth and a city's average cost of housing, the second uses labor contract cycles as an instrument for privatization, and the third compares transit costs between buses and subways (which, by their nature cannot be privatized) for cities that have both modes of transportation. Although these strategies are based on different identification assumptions, the empirical findings from these robustness checks are all consistent with those from the RDD.

${ }^{14}$ Between 1998 and 2014, the Amalgamated Transit Union (the largest transit worker's union in the nation), allocated an average of $93 \%$ of its political campaign contributions to democratic candidates (see OpenSecrets.org Center for Responsive Politics).
} 
equal, a republican mayor is more likely to engage in privatizing compared to a democratic mayor. We exploit the discontinuity in treatment levels generated by narrowly won mayoral elections as a source of pseudo-random assignment of privatization.

In an RD framework, whether the winning margin of the democratic candidate (i.e. the running variable) falls on one side of a fixed cutoff or the other partly determines treatment intensity. The winning margin is defined as the difference between the percentages of votes received by the winner and the runner-up. A winning margin of $0 \%$ is the fixed cutoff determining the political party of the winner; a $0 \%$ winning margin implies both the republican and the democrat received $50 \%$ of the total vote share. We define the winning margin to be positive if the democratic candidate won, and negative if the republican candidate won. ${ }^{15}$

The critical assumption underlying our empirical strategy is that transit agencies in cities with mayoral elections in a narrow window around the 0 winning margin threshold are similar on observable and unobservable dimensions. ${ }^{16}$ We verify in the next section that covariates other than the treatment level (privatization share) that might affect the outcome of interest (labor costs) do not change discontinuously at the winning margin threshold for democratic victory. Further, although political party affiliation does not perfectly determine privatization., the probability of treatment changes sharply at the winning margin threshold. The discontinuity we use is fuzzy because there is non-compliance to engage in privatization: some agencies with republican mayors do not privatize and some agencies with democratic mayors do privatize. However, we show in Figure 5 that agencies in cities where the republican candidate won are significantly more likely to privatize a portion of their operations. The data used to generate Figure 5 are explained in greater detail in the next section.

A second critical assumption for a valid RD design is that transit agencies cannot precisely manipulate mayoral election voting outcomes, and subsequently select into the treatment (Lee \& Lemieux 2010). While this assumption is not directly testable, we provide evidence in the next section to obviate concerns about manipulation of the running variable. It is unlikely that for our sample of election outcomes with voter turnout ranging from 3,000 to 257,000 (in cities with populations ranging

\footnotetext{
${ }^{15}$ The winning margin ranges from -1 to 1 and it takes value -1 if none of the candidates are democrats and 1 if all the candidates are democrats.

${ }^{16}$ See Lee and Lemieux (2010) for a comprehensive discussion of regression discontinuity designs.
} 
from 59,000 to 1.8 million), voters were able to precisely manipulate voting outcomes. ${ }^{17}$ The evidence described in the next section suggests that there is no impact of the treatment on sample selection. Consequently, for transit agencies in UZA's with close margins of victory, the political affiliation of republican or democrat is assigned essentially at random. To the extent that political affiliation impacts public transit operating costs only through its effect on privatization levels, mayoral political affiliation may act as an instrument for a transit agency’s privatization share.

Our empirical model of the privatization decision is specified as follows:

$$
d_{i t}=\lambda L_{i t}+P\left(M_{i t} ; \kappa\right)+z_{i t} \delta+\epsilon_{i t}
$$

where $L_{i t}$ is the dummy variable being 1 for a democrat mayor and zero otherwise. $P\left(M_{i t} ; \kappa\right)$ is a flexible polynomial function of the Democrat's winning margin $\left(M_{i t}\right) . z_{i t}$ includes other control variables including fixed effects. Equation (8) provides the first-stage regression in the analysis of the cost equation (7). Our preferred specification for the control function $P$ is quadratic, however we show in Figure 5 our results vary little after using cubic or quartic polynomials. For all specifications, we allow the polynomial coefficients to differ above and below the cutoff. We estimate the treatment effect using two-stage least squares, following Hahn, Todd, and van der Klaaw (2001).

Comparing outcomes across UZA's within a sufficiently narrow window around the winning margin cutoff permits one to draw causal inferences regarding the effects of privatization on public transit operating costs. Our fuzzy RD design provides a weighted average of the effects of privatization for transit agencies in UZA's with mayoral elections near the winning margin threshold, where weights reflect the ex ante likelihood that of the agency's mayoral winning margin being close to the threshold. We test for heterogeneous treatment effects and find substantial variation in the effect of privatization on labor costs, depending on whether an agency operates in a state with strong or weak bargaining rights laws, and depending on the transit agency size.

\footnotetext{
${ }^{17}$ Near the winning margin threshold, voter turnout is comparable for UZA's on either side of the threshold. Average voter turnout is 48,500 for elections where the winner won by less than $20 \%$ of the vote share. Voter turnout is negatively correlated with winning margin. DiNardo and Lee (2004) observe this same trend in their analysis of union elections. The smallest voter turnout in their sample is 20 , substantially smaller than the voter turnout observed in our mayoral elections.
} 


\section{Data Source and Description}

\subsection{Data Sources}

Our primary data source is the government-sponsored National Transit Database (NTD). Any transit agency that receives grants or financing from the Federal Transit Administration must report data to the NTD. Our analysis focuses on transit agencies providing fixed-route, public bus transit. We obtained information on annual vehicle miles traveled (VMT), passenger miles traveled (PMT), operating costs, fuel use, fleet characteristics, and number of accidents and fatalities per year for 328 transit agencies from 1998 to 2011, for a total of 3,706 transit agency-year observations. Our sample of transit agencies includes all 50 of the largest public agencies that operate buses, as ranked by passenger trips as of 2011. ${ }^{18}$ These data cover 236 distinct urbanized areas (UZA's) across the U.S. Agencies are required to partition their reported operating cost and service information between services that were directly operated and those that were outsourced to a private contractor. We construct the privatization share by dividing the reported privatized VMT by total annual VMT. As of 2011, approximately 43 percent of transit agencies outsourced their operations to some degree between 1998 and 2011. Of those transit agencies, roughly half privatized 100 percent of their VMT for at least one year between 1998 and 2011. Fleet characteristics sourced from NTD include the size and average age of the bus fleet, the share of the fleet that is hybrid or operating on compressed natural gas (CNG), and the organizational type. We codify transit agencies as: an independent agency, a city agency, or “other” which includes agencies operated by the state DOT or planning agency subsidiaries. ${ }^{19}$

NTD reports operating costs which includes labor costs (salaries, wages, benefits, and pensions), costs of fuel, materials and supplies, utility costs, taxes, and liability costs. They do not report these individual components separately. They do report fuel usage data and based on fuel prices from the U.S. Energy Information Administration, we can construct the fuel costs. Based on reported operating costs and fuel costs estimates, we calculate the operating costs net of fuel costs. The labor cost is the major component and in our analysis below, and are calculated as operating costs net of fuel costs. Appendix 1 provides a discussion of the calculation of these cost measures.

The UZA-level data used in our empirical analysis consists of wages, unionization shares, average housing prices, a road congestion index, and population density. Because employee wages are not observed through the NTD data, we used earnings data from 1998 to 2011 from the Bureau of Labor

\footnotetext{
${ }^{18} 2013$ Public Transportation Fact Book. American Public Transportation Association. 64 ${ }^{\text {th }}$ edition.

19 See the online appendix for a detailed definition of each transit agency type included in the analysis.
} 
Statistics Current Population Survey (CPS) to approximate transit agency labor costs. ${ }^{20}$ Unionization share is the ratio of union-represented full time-equivalent (FTE) workers to all FTE workers, also sourced from CPS. Population density is sourced from NTD, and covers years 2000 and 2010. Annual average housing price data are sourced from ACCRA Cost of Living Index.

State collective bargaining rights strength and right -to-work data are sourced from Valletta and Freeman (1988). We use the 1996 updated values extended by Kim Rueben in our analysis. While the timing of the state collective bargaining data does not overlap with our analysis, year-to-year variation of a state's collective bargaining right strength is minimal. See footnote 6 for further explanation on the construction of this variable.

Part of the mayoral election data comes from Ferreira and Gyourko (2009). These data include the names, political affiliation, and winning margin for elections across 128 urbanized areas. Their data are limited to cities with populations over 25,000 with direct mayoral elections, covering years 1998 through 2008. We extended their data up through 2011. The Ferreira and Gyourko sample is observationally similar to the population of U.S. cities that met their criteria, but did not respond to their survey. Our own sample comprises the subset of urbanized areas from Ferreira and Gyourko's dataset that have public bus transit systems reporting to NTD.

\subsection{RD Validity Tests}

The sample we use in our RD estimation includes only the dominant transit agencies in a given UZA. We define “dominant” transit agencies as the largest transit agency in the UZA, based on average annual vehicle miles traveled. Using only the dominant transit agencies effectively creates a one-to-one match within our sample between a city and a transit agency. ${ }^{21}$

The critical identifying assumption underlying the RD design is that unobservable determinants of transit agency labor costs $l_{i t}$ do not differ among agencies within a narrow window of the 0 -winning margin threshold. We provide descriptive evidence as well as a formal test that there is no discontinuity in the distribution of the running variable at the cutoff. Any evidence of a jump in the density of the

\footnotetext{
${ }^{20}$ Our wage data consists of weekly earnings for full-time equivalent (FTE) workers who have earned a high school diploma, or less. We removed observations of earners below the $5^{\text {th }}$ and above the $95^{\text {th }}$ percentile.

${ }^{21}$ We focus on the dominant transit agencies for the RD approach for the following reasons. First, the privatization decision of these agencies have more significant implications on the local budget than non-dominant agencies. The bottom panel of Appendix Figure 2 plots the privatization share in non-dominant agencies against the winning margin and there does not appear to be a discontinuity in the privatization share by the mayor party among close elections. Second, the non-dominant transit agencies tend to be those that serve suburban areas and their service area may overlap with multiple municipalities. Thus, the connection between a city mayor's political decisions and the city's public services is less clearly defined for such non-centralized transit services. For these two reasons, we focus on dominant transit agencies in our RD analysis below.
} 
running variable at the cutoff would suggest a degree of sorting into the treatment and would invalidate the quasi-experimental RD design.

In Figure 4, we plot the density of observations in several bins of the winning margin over a 60percentage point window around the 0 -winning margin cutoff. There is no indication of discontinuity in the density of the forcing variable at the cutoff. A McCrary (2008) test confirms that there is no statistically significant jump in the running variable density function at $0 .{ }^{22}$ This is consistent with a lack of any manipulation in the margin of victory that may undermine the RD design.

We provide further evidence that the observable baseline covariates evolve smoothly over the threshold. Table 4 presents the descriptive statistics for the transit agencies in our sample. Average values for UZA-level and transit agency-level characteristics are shown in 30-percentage-point bins around the winning margin threshold. Tests of the null hypothesis of continuity of each covariate against the alternative of a jump suggest that there is no sorting around the threshold. The last column of Table 4 shows the p-value of discontinuity estimates from second-order polynomial regression in democrat winning margin. ${ }^{23}$ We fail to reject continuity across the winning margin threshold for each covariate listed in Panels A and B. These results are consistent with the smooth density of the running variable (Figure 4), supporting that there is no sorting of transit agencies around the threshold. ${ }^{24}$ In contrast to the covariates, Panels C and D show clear evidence of greater privatization levels and lower labor costs for transit agencies where the republican candidate won an election.

Next, we present graphical evidence on the effects of democratic mayoral victories on a transit agency's level of privatized bus miles. Panel A of Figure 5 plots predicted values of privatization share using various control functions as well as mean values of privatization share within half-percentage point bins of the winning margin. There are noticeable discontinuities at the cutoff, with conspicuous drops in privatization levels within each bin for democratic winning margins greater than 0 .

Privatization levels, while significantly lower, are not zero for democratic victories; however it is clear

\footnotetext{
${ }^{22}$ The McCrary test is based on an estimator for the discontinuity at the cutoff in the density function of the running variable. The test involves, first obtaining a finely-gridded histogram of the running variable; and second, smoothing the histogram using local linear regression on either side of the cutoff. The parameter of interest is the log difference in histogram height to the right and left of the threshold. See McCrary (2008). The point estimate of a discontinuity in the density function is -0.41 with a standard error of 0.25 , consequently we can reject the null hypothesis that the running variable density function is discontinuous at the threshold.

${ }^{23}$ Specifically, we run regressions of the form: $y_{i t}=\beta_{0}+\tau D_{i}+\beta_{1} M_{i t}+\beta_{2} M_{i t}^{2}+\varepsilon_{i t}$ for $(|M| \leq 0.6)$. The P-value associated with the estimate of $\tau$ is listed in Table 4. $y$ is each covariate listed in Panels A and B, $M$ is the winning margin, and $D=1$ if the winning mayor is a democrat. Standard errors were clustered at the UZA level.

${ }^{24}$ Graphical evidence that baseline covariates evolve smoothly through the threshold is presented in the Appendix Figure 1.
} 
that there is a discrete increase in the probability of privatizing public bus transit operations in urbanized areas where a Republican won a mayoral election.

The likelihood of privatization differs across states with either strong or weak collective bargaining rights. Panel B of Figure 5 shows that most of the jump generated in the full sample shown in Panel A is driven by republican victories in states with strong collective bargaining rights. Agencies in weak bargaining rights states show very little difference in privatization levels regardless of whether the republican or democratic mayoral candidate won an election (Panel C).

Figure 5 may seem at odds with Figure 2, which shows how weighted average privatization levels are higher for weak bargaining rights states. However, the graphs are consistent when we consider the opportunity cost of privatizing: for weak bargaining rights states, the opportunity cost is lower due to the fact that these states tend to have lower wages, less union power, smaller city sizes, and lower urban density. In contrast, the potential cost savings is greater in strong bargaining rights states. Consequently, the republican winner is more likely to capitalize on such potential cost savings and privatize; whereas the probability of privatizing is very low for cities with democratic mayors in strong bargaining rights states relative to weak bargaining rights states. Our analysis below will account for this heterogeneous treatment effect across strong versus weak bargaining rights states.

To improve estimation efficiency, we utilize the full sample of 1,444 transit agency-years in our main RD results. However, our estimates are robust to restricting observations to elections with margins of victory closer to the winning threshold. Appendix Figure 3 shows the discontinuity zoomed into elections with winning margins within $60 \%$ of the cut-off. The jump in privatization levels for republican mayors is even more evident within a narrow window of the winning margin threshold, and the difference in privatization levels persists across strong relative to weak bargaining rights states. In Section 6, we document how the regression discontinuity estimate in privatization levels is robust to different windows around the threshold.

Given the substantial discontinuity in privatization levels across the winning margin threshold, and given that other covariates are distributed smoothly across the threshold, one can interpret any discontinuity in the conditional distribution of unit labor costs as a causal effect of the privatization. 


\section{Empirical Results}

The analysis of bus transit labor costs suggests that the private provision of public bus transit is more cost-effective than public provision of public bus transit. Public sector unions are a significant driver of the cost differentials between the private and public operations. The public sector unions appear to extract higher rents when associated with larger transit agencies, when state-level collective bargaining rights are stronger, and when local political leaders are democrats.

\subsection{The Determinants of Privatization}

Regression estimates of the discontinuities in privatization share are shown in Table 5A. Each cell in the first row reports an estimate of the effect of democratic major on privatization $(\lambda)$ across various specifications of equation (8). All specifications include quadratic control functions and their interactions with the mayor party dummy. Standard errors are clustered at the UZA level, thus allowing for arbitrary correlation in errors for transit agencies within the same UZA. As we would predict from the discontinuity gaps found in Figure 5, regression results demonstrate that a Democratic mayoral victory reduces the likelihood of privatizing bus miles. Results are robust to the specification of the control function or the inclusion of covariates. All estimates are significant at the $10 \%$ level.

In Column (3), we allow the discontinuity estimate to differ for states with strong vs. weak collective bargaining rights laws by including an interaction of the democrat mayor indicator with strong bargaining rights indicator (“Democrat* Strong Barg”). This variable is equal to 1 for a transit agency operating in a strong bargaining rights state in a year where a Democrat mayor was elected, 0 otherwise. The negative coefficient on "Democrat* Strong Barg” implies that democrat mayors in cities with strong bargaining rights are even less likely to engage in privatization than their weak bargaining rights mayoral counterparts. The estimates in column (3) are jointly significant with 95\% confidence level.

Column (4) uses local polynomial regression estimation with a robust confidence interval developed by Calonico, Cattaneo, and Titiunik (2014, henceforth CCT). The performance of available local polynomial confidence intervals are sensitive to the chosen bandwidth, and can produce biased intervals with low empirical coverage in finite samples. The confidence interval proposed by CCT corrects for this bias by rescaling the conventional bias-corrected t-statistic with a standard error formula that accounts for the additional variation introduced by the estimate bias. The resulting confidence 
interval allows for mean squared optimal bandwidth selectors, and improved coverage rates. ${ }^{25}$ Column (4) local polynomial regression estimate employs a triangular kernel density and bandwidths following the selection procedure of CCT (2014). Collectively, results of Table 5A suggest that a democratic mayor reduces privatization levels by between 6 and 10 percent.

We verify that the observed jump in privatization levels is, in fact, driven by the republican winning margin threshold by carrying out a placebo test. Our test employs a series of alternate, false, thresholds. In Figure 6, we plot the discontinuity estimates from a series of regressions run using 10 percentage-point windows around the 0 winning margin cutoff. For expository purposes, we show estimation results over the range -0.4 to 0.4 . Estimates are from local polynomial regressions around the false thresholds. Each regression includes a quadratic polynomial in the winning margin. Estimates were noisier for thresholds below 0 due to smaller sample sizes. However, only at the true cutoff of 0 is the discontinuity estimate statistically significant.

\subsection{Regression Discontinuity Estimates}

We now investigate whether privatization reduces transit agency labor costs. Table 5B reports estimates of $d$ in equation (7) under three types of estimators: OLS, GMM - or the "fuzzy" RD - and the local polynomial estimator. We show results with and without UZA and agency control variables. All regressions include year and state dummies, so that the relationships between privatization levels and labor costs are identified off of variation across agencies within the same state. Standard errors are clustered at the UZA level. OLS estimates in columns (1) and (2) suggest that a 1\% increase in a transit agency's privatization share reduces their per-mile labor costs by between 0.16 and 0.37 percent. For a transit agency with no privatization, the per-mile labor cost-saving effect from fully privatizing transit operations is between 15.0 and 30.9 percent. ${ }^{26}$

However, the OLS estimates are likely to be biased by unobserved factors that are correlated with a transit agency’s level of privatization and which also affects labor costs. Columns (3) - (4) present analogous results under a GMM fuzzy RD approach in which we instrument the privatization

\footnotetext{
${ }^{25}$ See Calonico, Cattaneo, and Titiunik (2015) for a detailed discussion on the construction of their bias-corrected confidence intervals.

${ }^{26}$ Because equation (7) takes the semi-logarithmic functional form and the privatization rate ranges from 0 to 1 , a consistent estimator for the percentage impact from full privatization (e.g., privatization rate going from 0 to 1 ) on the labor cost is $100 *\left[\exp \left(\hat{\gamma}-\frac{\operatorname{var}(\widehat{\gamma})}{2}\right)-1\right]$.
} 
share with an indicator equal to 1 if a democrat won a mayoral election. The identifying assumption is that, conditional on observable UZA and agency controls (listed in Table 4), mayoral political party affiliation only affects transit agency labor costs through its effect on privatization levels. We have demonstrated in the previous section that mayoral political affiliation is strongly correlated with privatization levels.

The GMM estimates in columns (3) and (4) are larger in magnitude relative to the naïve specifications in columns (1) and (2). Thus, omitted variables produce a downward bias on the privatization effect. This is consistent with paradox described above whereby large cities with strong union have more to gain from privatization but are less likely to privatize. The fuzzy RD estimates suggest a 1 percent increase in privatization reduces unit labor costs between 0.4 and 1.9 percent for those transit agencies near the 50-50 margin of victory.

Columns (5) and (6) allow for heterogeneous treatment effects across strong vs. weak bargaining rights states. Again, the results show that outsourcing public transit to private entities by 1 percent will decrease labor costs per mile by between 1.0 percent and 2.1 percent. The full effect of privatization is a unit labor cost reduction ranging from 46.4 to 68.1 percent after controlling for observables. Finally, the local polynomial estimate in column (7) is a similar magnitude to the GMM estimates. Each estimate shown in Table 5B falls into the CCT robust confidence interval of [-4.145; -0.110].

Inclusion of UZA and transit agency control variables reduces the magnitude of the GMM estimates substantially. This highlights the importance for controlling for observables in our case. Higher cost transit agencies tend to be those located in larger cities, with higher cost of living, and high unionization rates. Ignoring such factors inflates the correlation between privatization and cost savings.

This magnitude of cost savings suggested by privatizing is immense. There are two probable causes for the substantial downward bias suggested by the OLS results. First, those transit agencies that have the greatest cost-saving potential are not engaging in privatization. Because the sample for the regression discontinuity analysis consists only of dominant transit agencies, the predicted cost savings are likely to be inflated. We investigate the particular relationships between transit agency size and labor costs in subsequent analyses and find dominant transit agencies have approximately 20 percent higher labor costs per mile relative to non-dominant transit agencies, ceteris paribus. Second, it is possible that public transit cost minimization is not the only objective of these larger agencies. For example, other 
political or social welfare objectives may render privatizing public transit suboptimal, even if it means leaving large sums of money on the table.

To further test the robustness of results to the identifying assumption, we estimate the effect of privatization based on three alternative strategies in Appendix 2. The first is an IV strategy where the IV is a Bartik measure of state employment growth interacting with a city's average cost of housing. The second strategy uses labor contract cycles as an instrument for privatization, and the third strategy compares the operating costs per mile between buses and subways (which, by their nature cannot be privatized) for cities that have both modes of transportation. Although these strategies are based on different identification assumptions, the empirical findings from these robustness checks are all consistent with those from the RD estimates.

\subsection{Effects of Privatization on Service, Quality and Ridership}

Critics of privatization often point to worsening service quality as a drawback of outsourcing. Hart, Shleifer, and Vishny (1997) theorize that in-house service provision (in the context of prisons) is optimal if cost reductions from privatizing have substantial impacts on noncontractible quality. However, if quality reductions from cost reductions can be controlled through contracts or competition, then privatization is optimal. Therefore, the ability to measure and monitor service quality and its externalities are important factors that determine whether a public service can or should be privatized.

To test whether privatization impacts service quality on average, we estimate the effects of privatization on the number of non-fatal and fatal incidents reported by the transit agencies. Non-fatal incidents include collisions, vehicles leaving the roadway, fires, electric shocks, or security incidents. Fatal incidents include fatal collisions with pedestrians, cyclists, suicides, or operator deaths. These data were available from NTD from 2002 through 2011. Because both of these safety measures are count data with several zeros, we employ a negative binomial regression. Appendix Table 3 reports results from basic negative binomial regressions as well as $\mathrm{RD}$ and instrument variable specifications where negative binomial is employed in the second stage. In three of the four specifications, privatization share is negatively correlated with the number of reported incidents per year. None of the specifications produce a statistically significant relationship. These results fail to show that privatization alters the safety and security of bus transit at least, and prevents accidents and fatalities, at best. 
We further test whether transit agencies that outsource are more likely to reduce transit services or if unobservable factors cause ridership to decline when operations are managed by a private entity. Evidence of the former would confound the cost-saving effects identified in the prior analyses. Specifically, privatizing might reduce costs not through efficient management, but through reducing the services rendered to the public. We test for these confounding factors directly by estimating equation (7) where vehicle miles traveled and ridership are the dependent variable. Appendix Table 4 shows the results of these VMT and ridership regressions estimated using OLS, fuzzy RD, and the IV approaches. Privatizing bus transit is positively correlated with vehicle miles traveled (columns 1-3). The relationship is only significant in the OLS specification. These results suggest privatizing does not significantly alter the services rendered by transit agencies, thus the observed cost savings are not generated by service-cutting.

Finally, we test whether privatizing affects overall bus ridership. We measure ridership as the ratio of annual passenger miles traveled to annual vehicle miles traveled. It is possible that privatizing firms alter services in such a way that less people prefer to take public bus transit. Such a result would confound the cost-savings effect but would more importantly suggest that privatizing has welfarediminishing effects by pushing people away from public transit. Columns (4)-(6) show that privatization does not significantly affect ridership.

These analyses suggest that private firms provide public bus transit at a lower cost than public operators, and these cost savings do not come at the expense of reduced miles of service or reduced quality. Appendix 3 examines the heterogeneous treatment effect of privatization across transit agencies. The analysis shows that the effect of privatization on labor costs are stronger for larger transit agencies as well as for transit agencies in strong collective bargaining states.

\subsection{The Cost-Saving Mechanisms Induced by Privatization}

Our research suggests that the two main avenues through which non-privatized, unionized labor increases costs are through limiting the transit agency's use of part-time employees, and through negotiating increased pensions and fringe benefits. ${ }^{27}$ We test whether publicly operated transit services exhibit underutilization of employees or "featherbedding" of employee headcount within our NTD dataset. Due to the limitations of NTD data, we observe employee headcount only for the publicly operated transit services, thus we are not able to compare employee headcount for public and private

\footnotetext{
${ }^{27}$ See Giuliano and Lave (1989), Black (1991), DiSalvo (2010), and Winston (2010).
} 
operations directly. However, we are able to test the effect of state-level union strength on full-time employee headcount, holding all other factors constant, for publicly operated transit services. Table 6 shows results of regressing state-level bargaining rights and a right-to-work state indicator on the log of number of full time employees per publicly operated VMT. Stronger state bargaining rights are correlated with higher full-time employee headcount per VMT. Conversely, transit agencies operating in right-to-work states have lower full-time employee headcount per VMT. The negative correlation between right-to-work laws and employee headcount per VMT persists even for transit agencies operating in states with strong collective bargaining rights.

Results of these headcount regressions are informative, but may suffer from omitted variable bias if factors we have not accounted for impact both the headcount intensity of a transit as well as the legal rights of unions (i.e., public demand for bus services). To control for the existence of omitted variables, we look at transit agencies in counties that share a state border, where right-to-work laws differ on either side of the state border. For instance, Kansas - a right-to-work state, and Missouri - a non-right-to-work state - share a border. We compare the transit labor costs between transit agencies in two counties that share the Kansas-Missouri border. These counties are arguably comparable on unobservables due to their close geographic proximity. After controlling for city and agency-specific observables like average wage, union strength, density, and cost of living, any variation in labor costs between these two agencies is due to their differing right-to-work status. The NTD data consists of 17 such border-county pairs comprising 21 transit agencies. Table 7 shows the results of fixed effect regressions. Each specification includes the 17 border-pair fixed effects. The sample size is small, however the right-to-work estimate is precisely estimated, and is robust to the inclusion of various fixed effects and UZA and agency controls. The evidence in Tables 6 and 7 suggest that right-to-work states have lower labor costs, all else equal, and leaner use of staff is at least partially responsible for these lower labor costs.

As a final piece of evidence demonstrating the role that unions play in lobbying large liberal city transit agencies, in Table 8 we report regressions in which the dependent variable is the log of operating cost per mile and the independent variables are dominant agency indicators and their interactions with right-to-work status and union strength. These regressions include UZA-by-year fixed effects, which serve to control for all local trends that can impact operating costs. The remaining variation is withincity transit agency variation. Since major UZAs such as Chicago have multiple transit agencies, we compare the within UZA cost per bus mile for dominant transit agencies and suburban agencies. In 
addition, we stratify these estimates by the state's right-to-work status. In pro-union, non-right-to-work states, operating costs are 36 percent higher in the dominant agency relative to the suburban agencies but in right-to-work states such as Texas, operating costs are only 3 percent higher in the dominant agency relative to the suburban agencies (see Table 8 column 2). Again, these results include UZA-by-year fixed effects and thus highlight the central role that unions play in liberal areas.

An important dimension of the privatizing process is that the employees operating and maintaining buses are often the same people whether the bus is operated by the private or public entity. The majority of these employees are unionized, even if they are on payroll of the private entity. Thus, the impact of unions on transit operating costs is not absent when operations are outsourced to private firms. Rather, private firms are better equipped to negotiate labor contracts with union representatives.

Several private operators are large multinational firms that can draw upon best practices in contract negotiations and employee management. More importantly, private firms serve to create a disconnect between unionized transit employees and the transit authority responsible for budgeting and planning. Because of their affiliations with a political organization, public unions have the power to increase and sustain levels of public employment as well as impact local finance policy to increase taxes and salaries (DiSalvo (2010)). Severing the tie between the policy-making institution and the employees is one of the most important mechanisms by which private firms reduce costs of public services. ${ }^{28}$

\section{A Counterfactual Welfare Analysis of the Effects of Privatization}

We estimate the welfare loss from overpaying for public bus transit. To calculate, this we estimate the difference between societal costs at current privatization levels and counterfactual societal costs where all bus transit is privatized. We then compare the welfare loss from over-paying for transit services with the current societal benefit of transferring income to low-skill public sector employees.

Total passenger trips on fixed-route bus transit as of 2011 were approximately 5.2 billion. ${ }^{29}$ We use prior studies on transportation demand for our measure of bus ridership elasticity with respect to fare. ${ }^{30}$ Using the estimates for total operating costs per mile from the regression discontinuity design

\footnotetext{
${ }^{28}$ DiSalvo (2015) discusses important advantages that public sector unions exercise over private sector unions at the negotiations table including: protection from business cycles due to the ease with which governments can borrow money, influence on employers through political contributions, and absence of direct mechanisms to control management because voters are generally uninformed of local government spending.

${ }^{29}$ APTA 2013 Public Transportation Factbook, Table 5.

${ }^{30}$ Gagnepain and Ivalid (2002) estimate an elasticity of bus ridership with respect to fare of approximately -0.441. Oum, Waters, \& Young (1992) estimate elasticities between -0.3 and -0.7. TRCP Report 95 (2004) estimates an elasticity of -0.40.
} 
described in Section 6.3, we calculate the average predicted bus fare for a transit agency as of 2011 under current levels of privatization as $\alpha_{1}=\$ 3.00$. If all transit agencies privatized their operations completely, the average predicted bus fare as of 2011 would be $p_{1}=\$ 1.87$. Using the base bus fare $\alpha_{1}$, counterfactual bus fare $p_{1}$, the elasticity of bus ridership, and the aggregate number of passenger trips, we calculate the aggregate demand curve for bus passenger trips. (See Appendix 4 for further detail on calculations).

Figure 7 shows the predicted change in consumer welfare if all bus transportation were privatized and operated by private companies. The shaded area is the change in consumer surplus associated with privatization. Part of the change in consumer surplus is the result of a wealth transfer from consumers to public employees of transit agencies. Specifically, at least part of the differential between $\alpha_{1}$ and $p_{1}$ is a wealth transfer from consumers of transit to the employees of public transit in the form of higher wages. This portion of the welfare change is not necessarily inefficient. Area D in Figure 7 is pure deadweight loss associated with this transfer (or the net gain from fully privatizing). While there are benefits to society from employing individuals who might otherwise receive lower pay, the transfer is not costless. Since this transfer makes the public provision of transportation more expensive than it would be without the distortion, demand for passenger trips is pushed to lower levels than it would be if the cost of public transit were at the privatized level, indicated by the lower dashed line. Under efficient privatized operations, aggregate ridership would increase from 5.2 billion to approximately 6.2 billion passenger trips.

The national change in consumer surplus under the average impact of privatization on operating costs amounts to approximately $\$ 6.3$ billion. Pure deadweight loss from this welfare was approximately $\$ 524.3$ million. This means that of the wealth transfer generated for public transit operations - from consumers to public sector transit employees - \$524.3 million neither serves wealth redistributive purposes, nor is it compensated to transit riders for the inability to use transit at an efficient cost. Thus, under 2011 conditions, US taxpayers lost \$524.3 million in aggregate from over-paying for bus transit. These welfare measures capture losses in one year, 2011. Losses of similar magnitude exist for subsequent years.

An increase in ridership under lower-cost privatized operations means that privatization creates new jobs for bus operators. In 2011, public bus transit employed over 130,000 individuals in operations roles. These drivers served 5.2 billion passenger trips. Letting the ratio of drivers to trips hold constant, an increase in ridership demand to 6.2 billion trips translates into over 26,000 new bus operator jobs 
alone (not including new maintenance and managerial jobs that would also be necessary). In the case that workers occupying these new jobs value them more than their second best alternative, the 2011 $\$ 524.3$ million deadweight loss is a lower bound because it does not account for the welfare gain from employment and job creation.

City-specific welfare losses depend on the size of the city's transit agencies and the strength of their public sector unions. Urbanized areas with larger transit agencies or stronger unions experience greater cost savings from privatization. Thus, welfare losses from not privatizing are greater for such urbanized areas. We estimated heterogeneous impacts of privatization by interacting a transit agency's privatization share with their fleet size as well as the strength of their state's collective bargaining laws. Table 7 shows the results of the heterogeneous effects regression. Larger transit agencies as well as agencies in states with strong collective bargaining laws experience even greater cost savings from privatization relative to smaller agencies in weak collective bargaining law states. This finding suggests that several of the nation's largest transit agencies would reduce costs significantly by privatizing.

Table 9 shows the estimated change in consumer surplus and the corresponding deadweight loss in 2011 for three major transit agencies: Boston’s MBTA, Chicago’s CTA, and San Antonio’s VIA. Boston’s deadweight loss from inefficiently high transit costs for the MBTA amounts to approximately \$14.8 million, while Chicago’s CTA has estimated deadweight losses of approximately \$26.3 million. In this same year, Boston and Chicago received \$846 million and \$705 million, respectively, in public funding for operations. The deadweight loss from inefficiently high operating costs accounted for 1.7 and 3.7 percent, respectively, of local, state, and federal funding sources for these two agencies in 2011 alone.

Both Chicago and Boston operate in collective bargaining rights states, whereas collective bargaining is outlawed in Texas. Notice that deadweight losses for San Antonio's VIA are estimated to be substantially lower at approximately $\$ 4.2$ million. San Antonio’s fleet is half the size of Boston, however their estimated deadweight loss is less than one third that of Boston.

\section{Conclusion}

Our analysis of public sector efficiency in the provision of public bus transit suggests three important findings: First, the private sector provides a unit of bus transit service at a lower cost than the public sector. Second, such public sector cost premiums are higher for larger transit agencies, when state-level collective bargaining rights are stronger, and when local political leaders are democrats. 
Third, privately operated firms are able to curb labor costs per mile through efficient allocation of labor and through limiting instances of featherbedding. Strong union bargaining power in non-right-to-work states appears to increase the number of full time employees on pay roll, holding the service area constant. These effects are most pronounced for a city's largest transit agency, which suggests public sector unions shift their bargaining pressure toward the dominant transit agencies such as Chicago's CTA, New York's MTA, or Boston's MBTA. The operating cost per bus mile in Chicago's major transit agency in 2012 was $\$ 13.18$, or 175 percent that of the operating cost per bus mile in Houston's major transit agency.

In aggregate, the potential cost savings from privatizing all public bus transit is on the order of $\$ 5.7$ billion per year. Using RD estimation to identify the effect of privatization on total operating costs, we find that the difference in operating costs per mile between mean privatization levels as of 2011 and the counterfactual scenario when all bus miles are privatized is a decrease from $\$ 6.63$ to $\$ 4.16$ per mile. Holding total service mileage (2.3 billion VMT in 2011) constant, this per unit cost savings translates into an aggregate cost savings of approximately $\$ 5.7$ billion, or 30\% of aggregate operating expenses.

The documented potential for total government cost savings from outsourcing bus operations is likely to be an underestimate. Transit unions are crucial political engines in major cities (Koch 1984). Thus, concessions from public employers to the transit unions are very likely to spread across to other unions within a city and positively impact their negotiation power. Known as the "me-too" bargaining strategy, the practice of negotiating salaries and benefits based on that of other public employees has been attributed to state and local government budget deficits for example in California, New York, and Vancouver, BC. ${ }^{31}$ Future research should study the timing of public sector union contracts and the sequential game played by a big city mayor with the major public sector unions. Republican mayors may enjoy cost savings across the board after creating an early reputation for being tough negotiators.

\footnotetext{
${ }^{31}$ In regards to public union labor arbitration, Governing Magazine states: “That [“me-too” bargaining strategies] immediately rigs the game in favor of organized labor, because the unions can then game one public employer against another.” (Miller 2010)
} 


\section{REFERENCES}

Alesina, Alberto, Reza Baqir, and William Easterly. "Redistributive public employment.” Journal of Urban Economics 48, no. 2 (2000): 219-241.

Bartik, Timothy J. 1991. Who Benefits from State and Local Economic Development Policies? Kalamazoo, MI: W.E. Upjohn Institute for Employment Research.

Baumol, William J. "Macroeconomics of unbalanced growth: the anatomy of urban crisis." American economic review (1967): 415-426.

Berechman, J. Public Transit Economics and Deregulation Policy. Amsterdam: North-Holland, 1993.

Black, A. Privatization of Urban Transit: A Different Perspective. In Transportation Research Record 1297, TRB, National Research Council, Washington, D.C, 1991, p69-75.

Bloomberg Feb 24, 2013. “N.Y. MTA Labor Talks Drag as Union Fights Part-Time Bus Drivers,” by Esme Deprez. http://www.bloomberg.com/news/articles/2013-02-25/n-y-mta-labor-talks-drag-asunion-fights-part-time-bus-drivers

Boustan, Leah Platt, and Robert A. Margo. "Race, segregation, and postal employment: New evidence on spatial mismatch.” Journal of Urban Economics65, no. 1 (2009): 1-10.

Brueckner, Jan K., and David Neumark. "Beaches, Sunshine, and Public Sector Pay: Theory and Evidence on Amenities and Rent Extraction by Government Workers.” American Economic Journal: Economic Policy 6, no. 2 (2014): 198-230.

Calonico, Sebastian, Matias Cattaneo, and Rocio Titiunik. 2014. "Robust Nonparametric Confidence Intervals for Regression-Discontinuity Designs.” Econometrica 82(6):2295-2326

Deaton, Angus. “A Reconsideration of the Empirical Implications of Additive Preferences," Economic Journal, Vol. 84, No. 334 (1974).

Diamond, Rebecca (2016). "Housing Supply Elasticity and Rent Extraction by State and Local Governments.” American Economic Journal: Policy (R\&R).

DiNardo, John, and David Lee. 2004. "Economic Impacts of New Unionization on Private Sector Employers: 1984-2001.” The Quarterly Journal of Economics. 119(4): 1383-1441.

DiSalvo, Daniel. "The trouble with public sector unions." National Affairs 5 (2010): 3-19.

DiSalvo, Daniel (2015). Government Against Itself: Public Union Power and Its Consequences. New York: Oxford University Press. Print.

Ferreira, Fernando and Joseph Gyourko (2009). "Do Political Parties Matter? Evidence from U.S. Cities.” The Quarterly Journal of Economics Vol. 124 (1): 399-422.

Freeman, Richard B., and Robert Valletta. "The effects of public sector labor laws on labor market institutions and outcomes." In When public sector workers unionize, pp. 81-106. University of Chicago Press, 1988.

Gagnepain, Philippe, and Marc Ivalid. "Incentive Regulatory Policies: The Case of Public Transit Systems in France.” The RAND Journal of Economics, Vol. 33, No. 4 (2002), pp. 605-629.

Gerber, Elizabeth, and Daniel Hopkins "When Mayors Matter: Estimating the Impact of Mayoral Partisanship on City Policy.”. 2011. American Journal of Political Science. 55(2): 326-339.

Giuliano, Genevieve and Charles Lave (1989). "The High Cost of a Bargain: Winning the Right to Use Part-Time Transit Drivers.” Transportation Research, Part A: General Vol. 23A(2): 151-159.

Glaister, Stephen. 1974. "Generalised Consumer Surplus and Public Transport Pricing.” The Economic 
Journal, 84(336): 849-867.

Hahn, Jinyong, Petra Todd, and Wilbert van der Klaauw. 2001. "Identification and Estimation of Treatment Effects with a Regression-Discontinuity Design.” Econometrica, 69(1):201-09.

Hart, Oliver, Andrei Schleifer, and Robert Vishny. (1997) “The Proper Scope of Government: Theory and an Application to Prisons” Quarterly Journal of Economics Vol 112 No 4. p 1127 - 1161.

Iseki, Hiroyuki, Amy Ford, and Rachel Factor. (2005) "Contracting Practice in Fixed Route Transit Service: Case Studies in California.” Transportation Research Record, No. 1927, p 82-91.

Koch, Edward I. Mayor: An Autobiography. New York: Simon and Schuster. 1984. Print.

Lave, Charles. "Measuring the Decline in Transit Productivity in the US.”Transportation Planning and Technology 15, no. 2-4 (1991): 115-124.

Lee, David and Thomas Lemieux (2010) “Regression Discontinuity Designs in economics” Journal of Economic Literature 48 (June 2010).

Levin, Jonathan and Steven Tadelis (2010). "Contracting for Government Services: Theory and Evidence from US Cities.” The Journal of Industrial Economics Vol. 58(3): 507-541.

Li, Shanjun, Matthew E. Kahn, and Jerry Nickelsburg (2015). "Public Transit Bus Procurement: The Role of Energy Prices, Regulation and Federal Subsidies.” Journal of Urban Economics, 87: 57-71,

Lopez-de-Silanes, Florencio , Andrei Shleifer, and Robert W Vishny. (1997). "Privatization in the United States." The RAND Journal of Economics, Vol. 28, No. 3 Autumn 1997: 447-471.

MacKechnie, Christopher (2015). "Designing Bus Routes and Schedules: Part I - V” About.com http://publictransport.about.com/od/Transit_Planning/a/How-Bus-Routes-And-Schedules-GetPlanned-Part-I-Placement-Of-Bus-Route.htm

McCrary, Justin. 2008. "Manipulation of the Running Variable in the Regression Discontinuity Design: A Density Test." Journal of Econometrics, 142(2): 698-714.

Miller, Girard. “The Arbitration Game.” Governing. 8 July 2010 http://www.governing.com/columns/public-money/labor-arbitration-in-new-economy.html

Mohring, Herbert. 1972. “Optimization and Scale Economies in Urban Bus Transportation.” American Economic Review. 62(4): 591-604.

OpenSecrets.org Center for Responsive Politics. “Influence \& Lobbying.” April 2015. https://www.opensecrets.org/pacs/lookup2.php?strID=C00032995\&cycle=2014

Oum, Tae Hoon, W.G. Waters II and Jong-Say Yong. "Concepts of Price Elasticities of Transport Demand and Recent Empirical Estimates: An Interpretative Survey.” Journal of Transport Economics and Policy, Vol. 26, No. 2 (1992): 139-154.

Richmond, J. The Private Provision of Public Transport. A. Alfred Taubman Center for State and local Government, John F. Kennedy School of Government, Harvard University, Cambridge, Mass., 2001.

Rosen, Harvey A. and Kenneth A. Small. "Applied Welfare Economics with Discrete Choice Models.” Econometrica. (1981).

Valletta, Robert, and Richard B. Freeman. Appendix B The NBER Public Sector Collective Bargaining Law Data Set. In When public sector workers unionize, pp. 399-420. University of Chicago Press, 1988.

Winston, Clifford. (2000) “Government Failure in Urban Transportation.” Fiscal Studies 21(4): 403425. 
Winston, Clifford. (2010). Last Exit: Privatization and Deregulation of the U.S. Transportation System. Brookings Institution Press. Washington, D.C.

Figure 1: Operating Costs Per Vehicle Miles Traveled (VMT) in States with Strong vs Weak Bargaining Rights

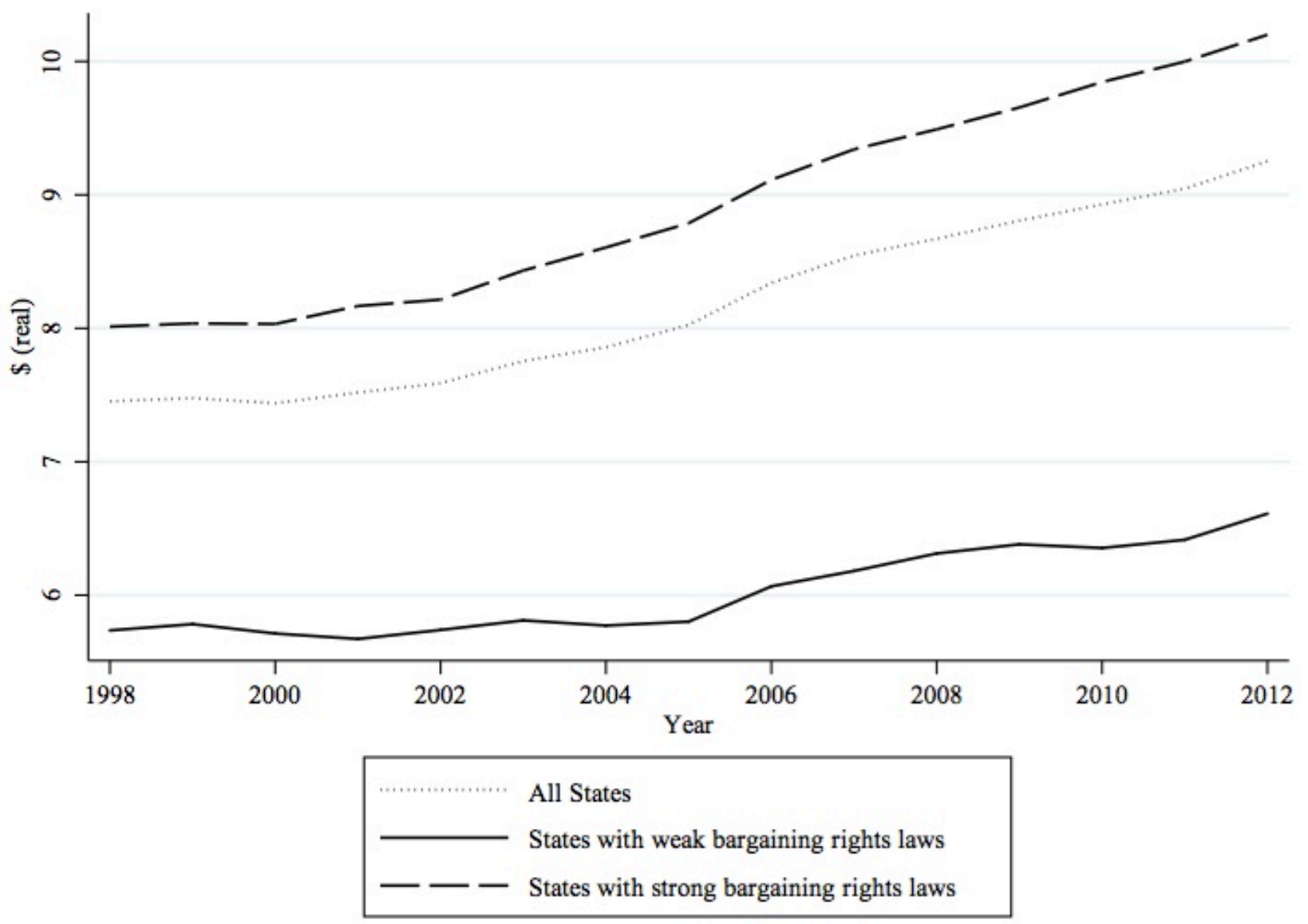

Note: Operating costs are deflated by CPI. Operating costs transit agency averages are weighted by transit agency annual VMT. States with strong bargaining rights laws are those where legislative mandate either implicitly or explicitly dictates public employers and union employees must come to an agreement on contract negotiations. States with weak bargaining rights laws either prohibit collective bargaining all together, or do not mandate that the public employer bargain with unions. Designation of "strong" vs "weak" bargaining rights states discussed in more detail in Footnote 7. State bargaining rights data sourced from: R.G. Valletta and R.B. Freeman (1988), "The NBER Public Sector Collective Bargaining Law Data Set." Appendix B. 
Figure 2: Share of Privately Supplied Vehicle Miles (Privatization Share) in

States with Strong vs. Weak Bargaining Rights

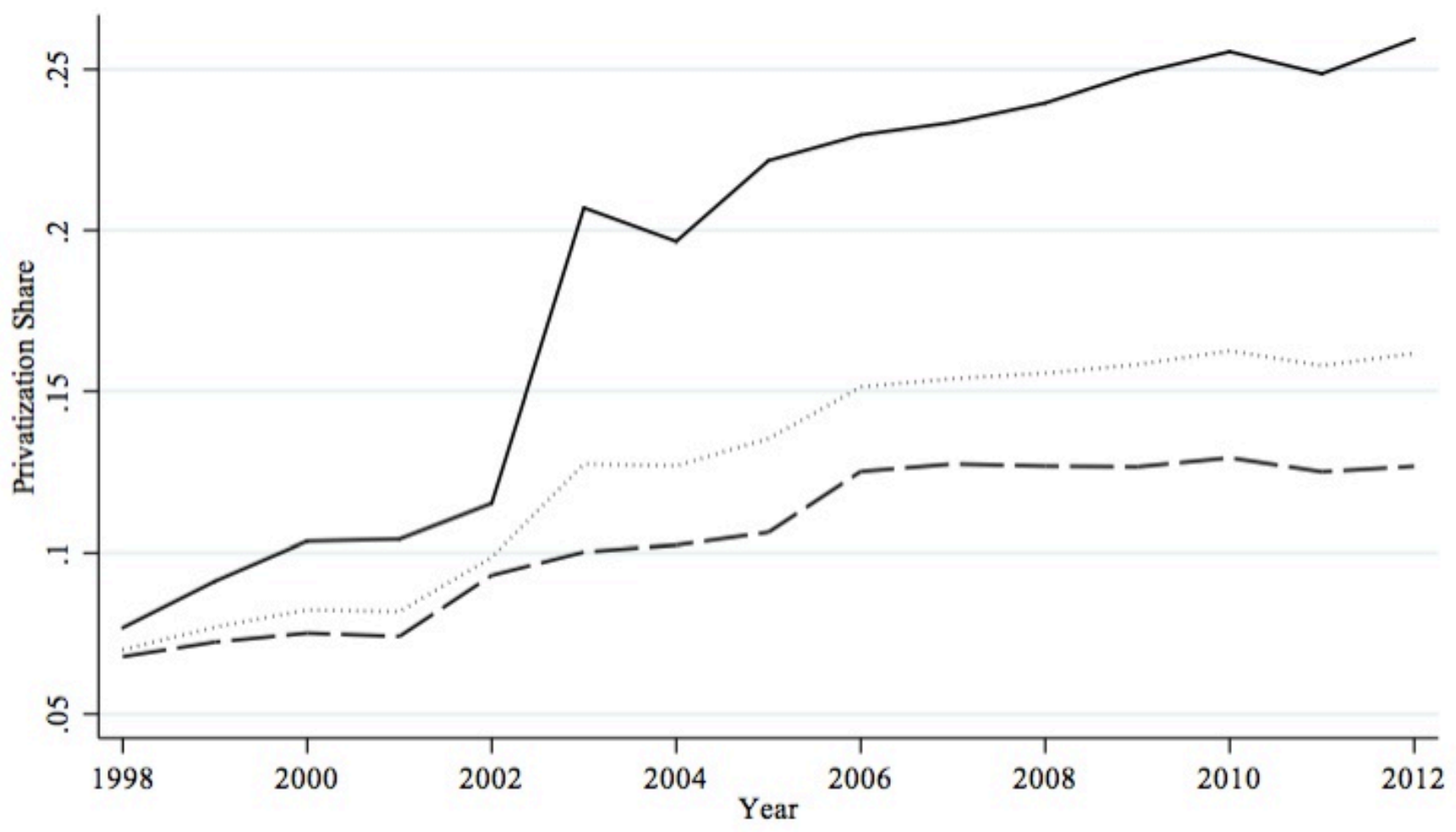

Note: This figures shows the privatization share among states with strong and weak bargaining rights laws States with strong bargaining rights laws are those where legislative mandate either implicitly or explicitly dictates public employers and union employees must come to an agreement on contract negotiations. States with weak bargaining rights laws either prohibit collective bargaining all together, or do not mandate that the public employer bargain with unions. Designation of "strong” vs "weak" bargaining rights states discussed in more detail in Footnote 7. Privatization shares are calculated as total annual VMT operated by private contractors divided by the total annual VMT. Privatization shares averages for strong and weak bargaining rights states are weighted by total annual VMT. The jump from 2002 to 2003 in weak bargaining-state privatization share is caused by three transit agencies that increased their privatization share by over 30\% between 2002 and 2003. These include agencies in Dallas, TX (DART), College station, TX (Brazos Transit District), and Phoenix, AZ (Valley Metro). 
Figure 3: Leontief Production Function for Bus Service Provision

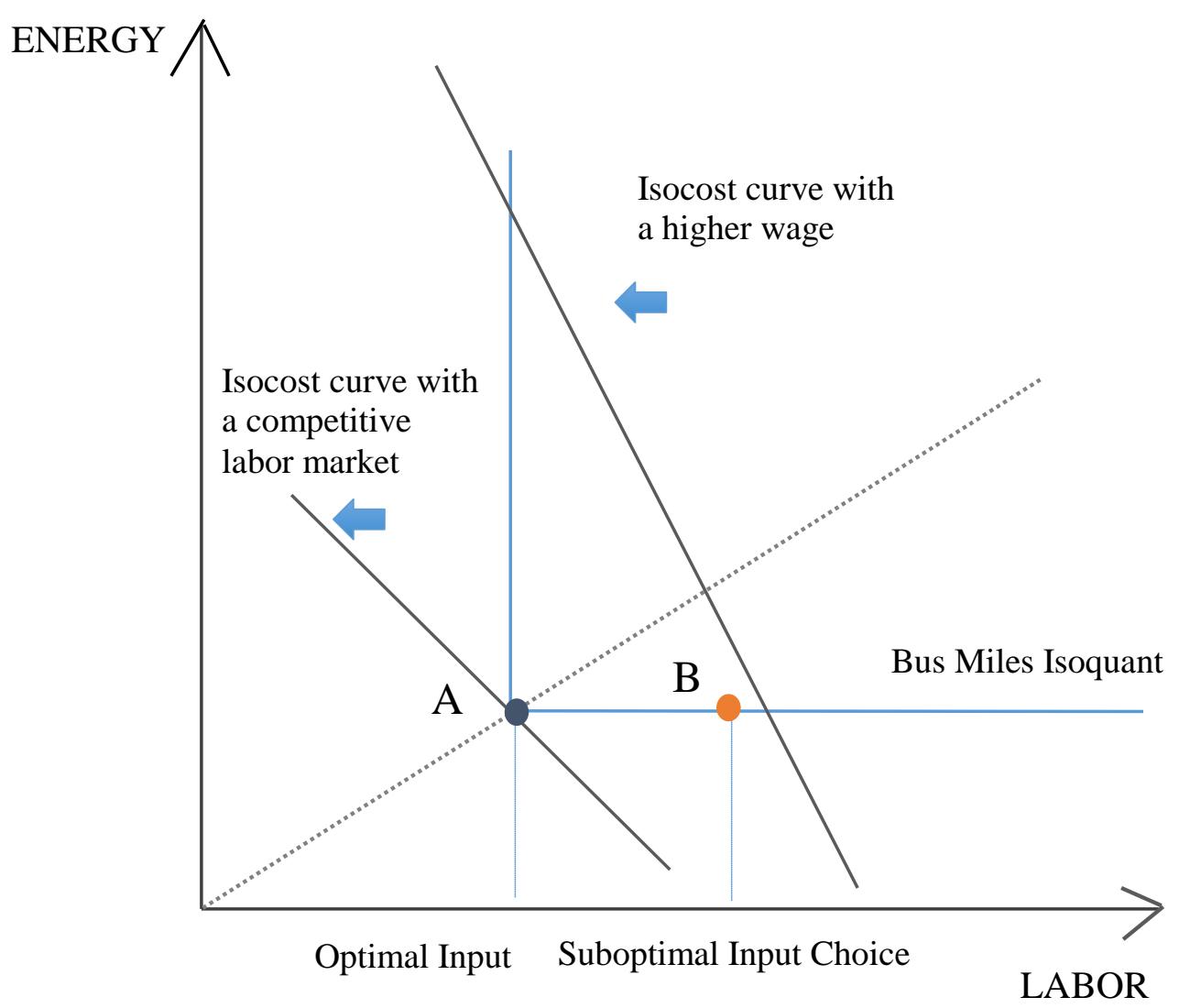

Note: The figure depicts the Leontief production of bus service based on energy and labor inputs. The steeper isocost curve reflects the higher wage paid to unionized workers as well as overutilization of labor from union work rules. Both a higher labor input and a higher wage lead to a higher cost of production for the same of amount of bus service provided. 
Figure 4: Density of the Winning Margin Running Variable $($ Bin size $=0.02)$

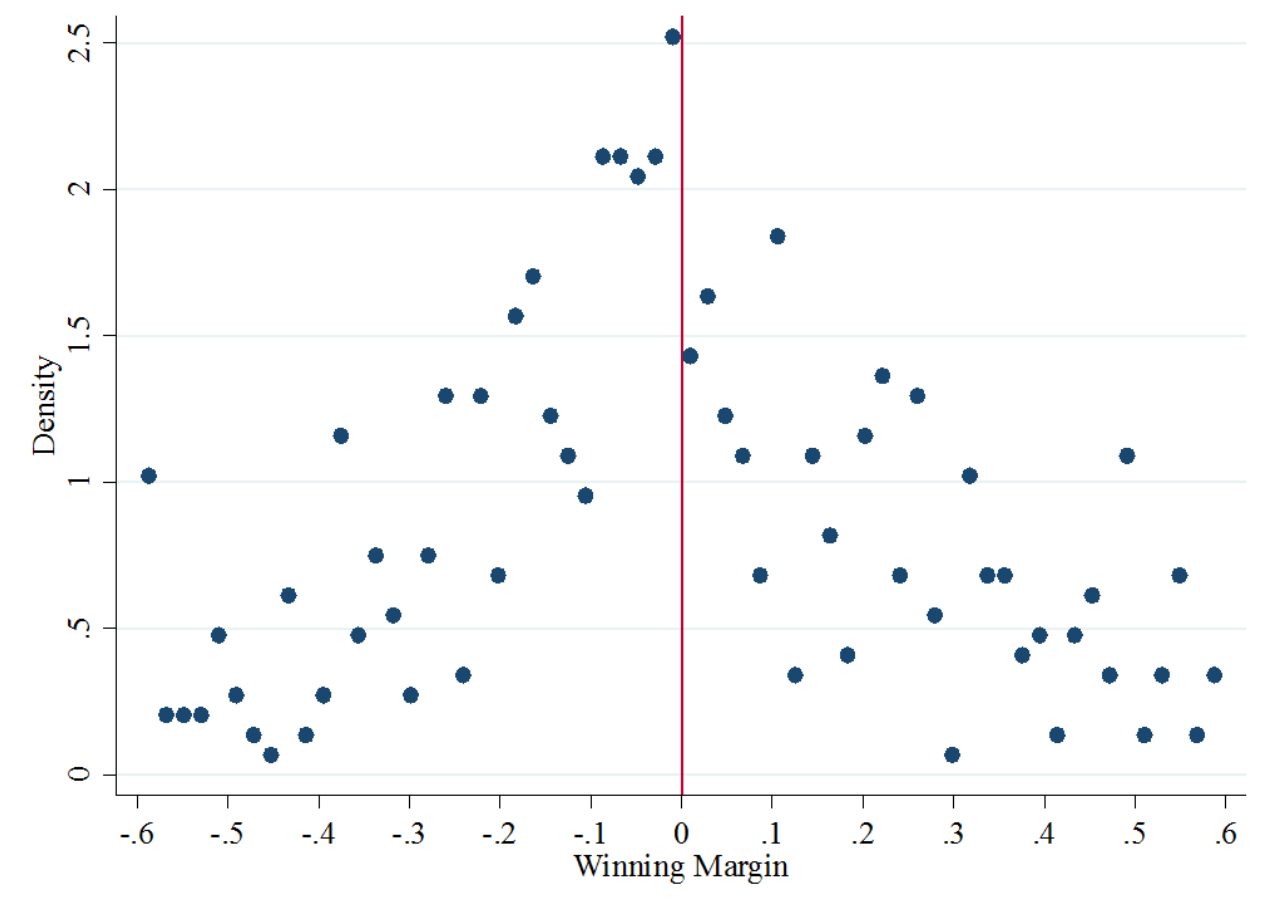


Figure 5: Privatization Share at the Democratic Winning Margin Threshold (Bin size=0.05)

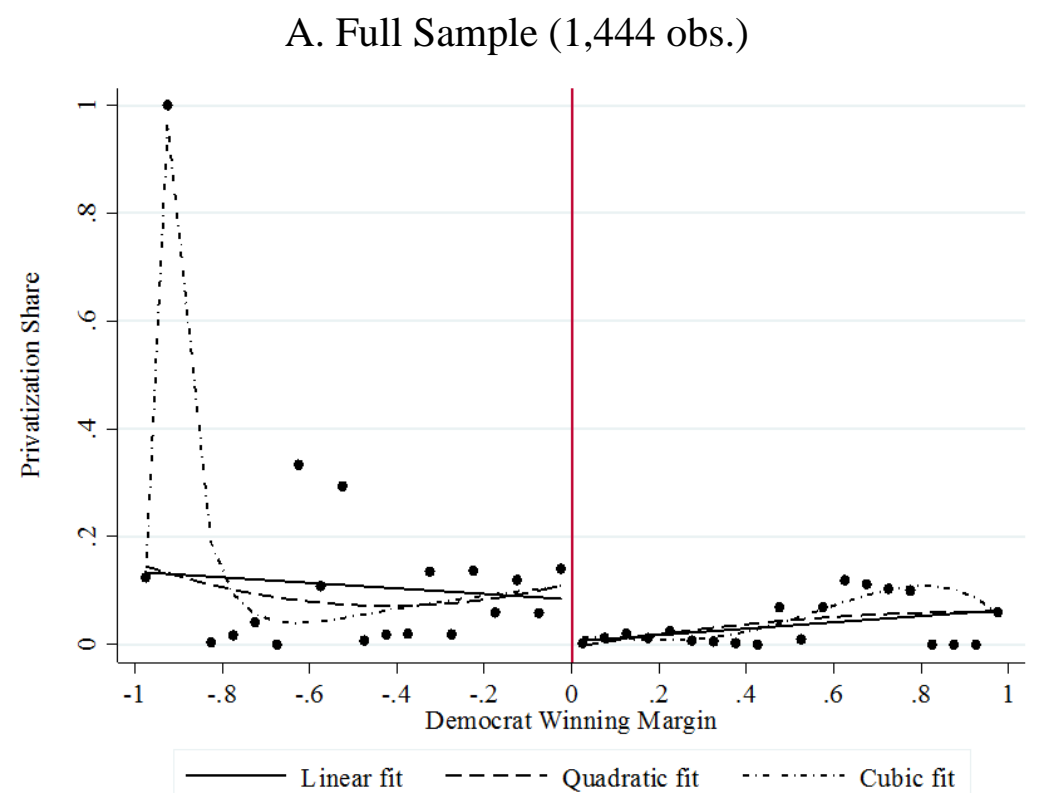

B. Agencies in Strong Bargaining Rights States (880 obs.)

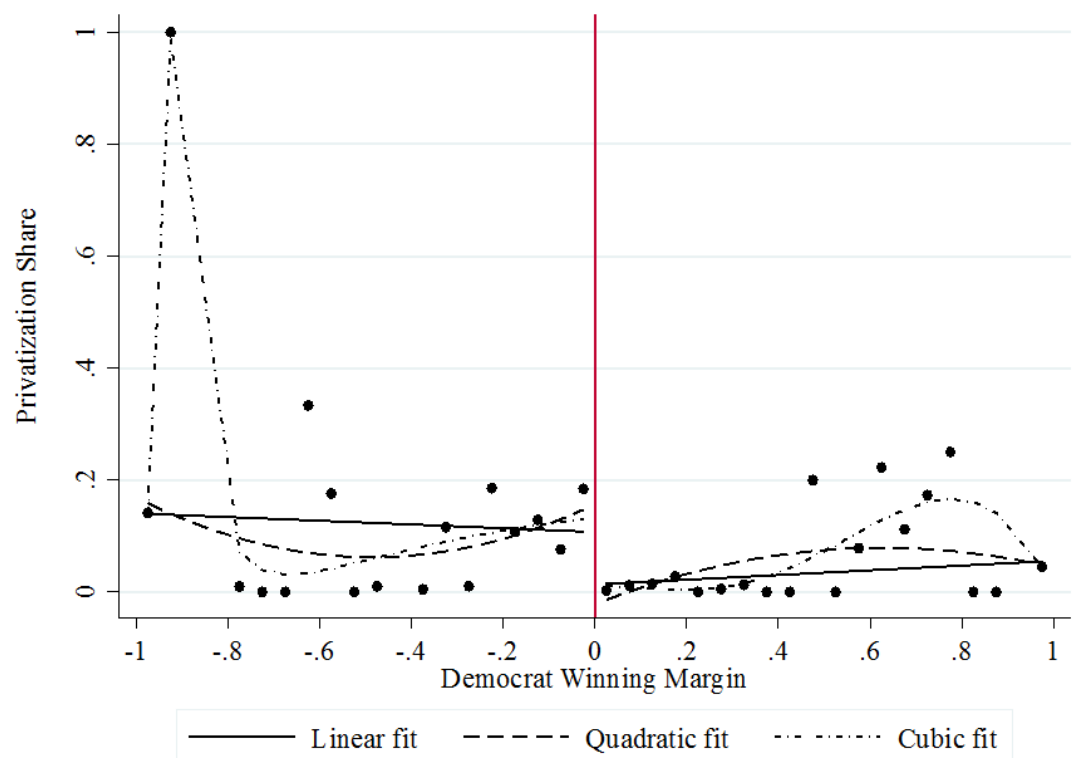

C. Agencies in Weak Bargaining Rights States (564 obs.)

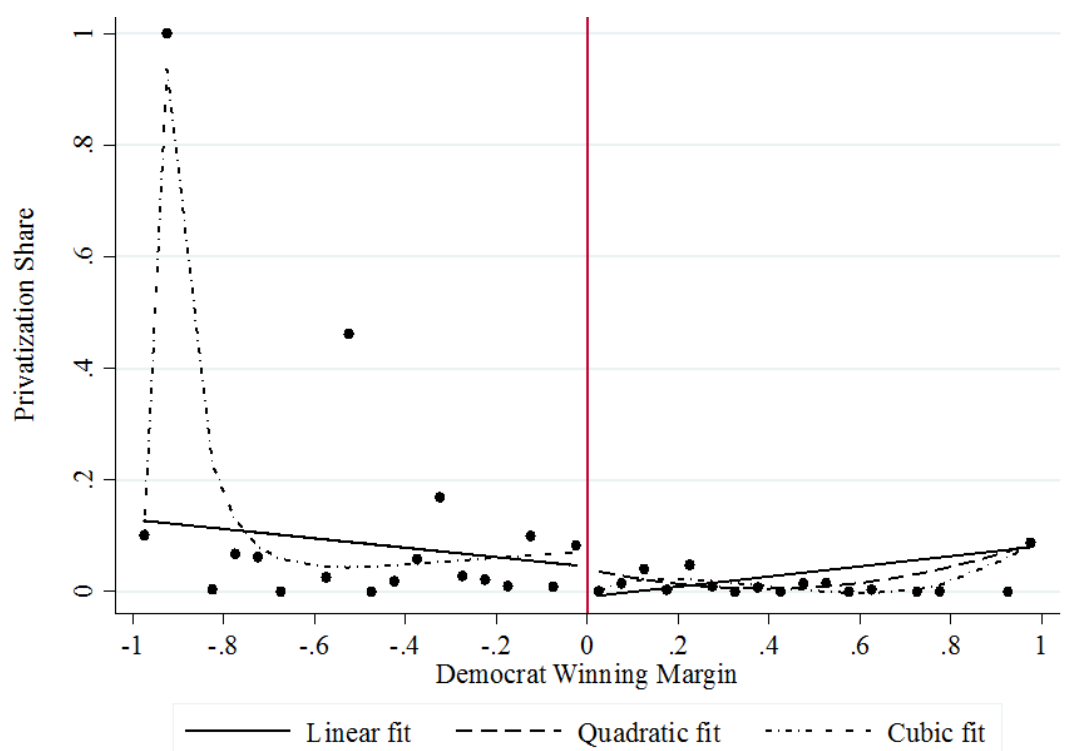


Figure 6: Placebo Discontinuity Estimates of Bus Transit Privatization Share

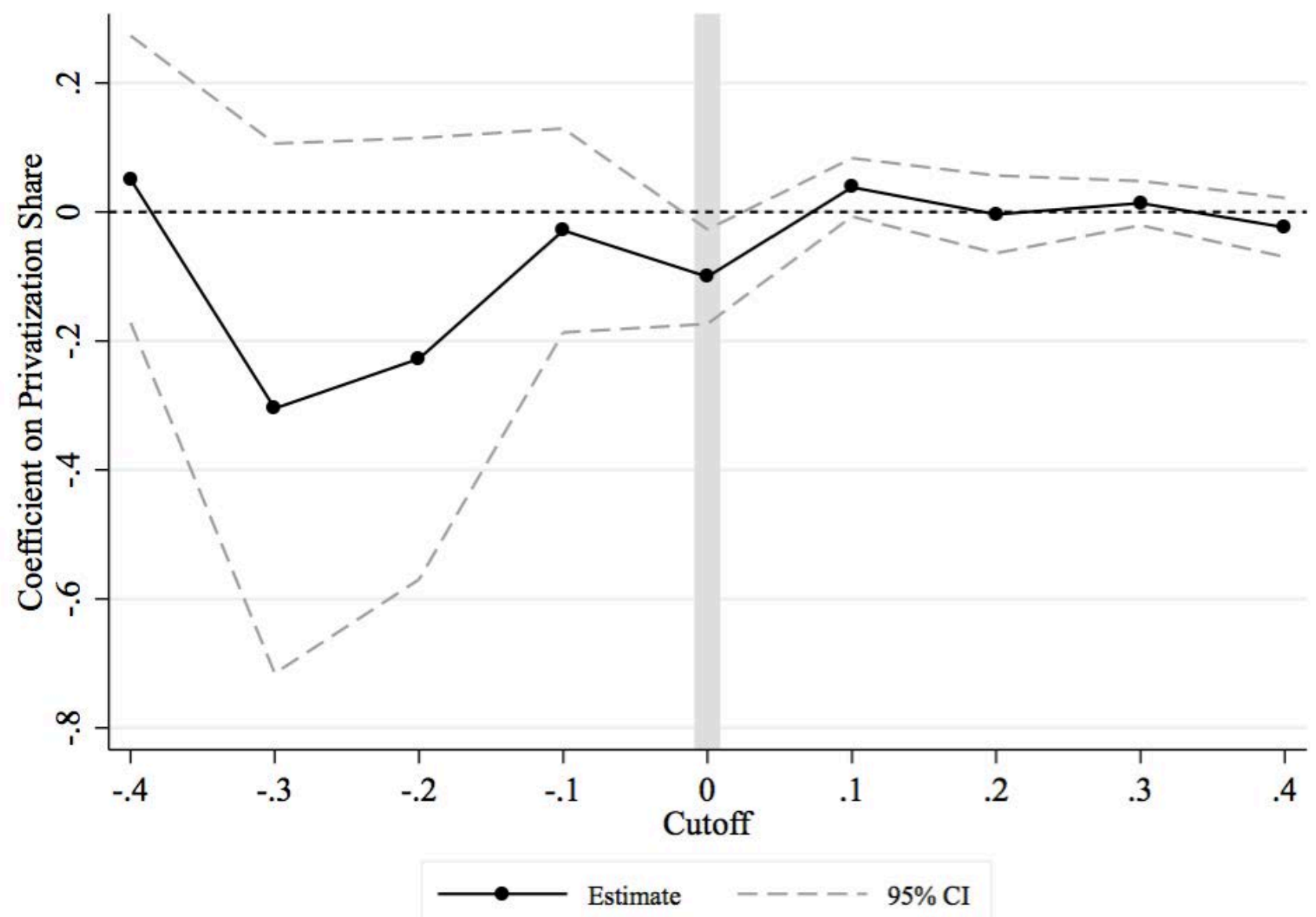

Note: Estimates based on local polynomial regressions with robust confidence intervals developed by Calonico, Cattaneo and Titiunik (“CCT”) (2014). Regressions include a quadratic in the winning margin. Kernel type is triangular. Bandwidth type is CCT. 
Figure 7: Loss in US Aggregate Consumer Welfare from Inefficient Bus Transit

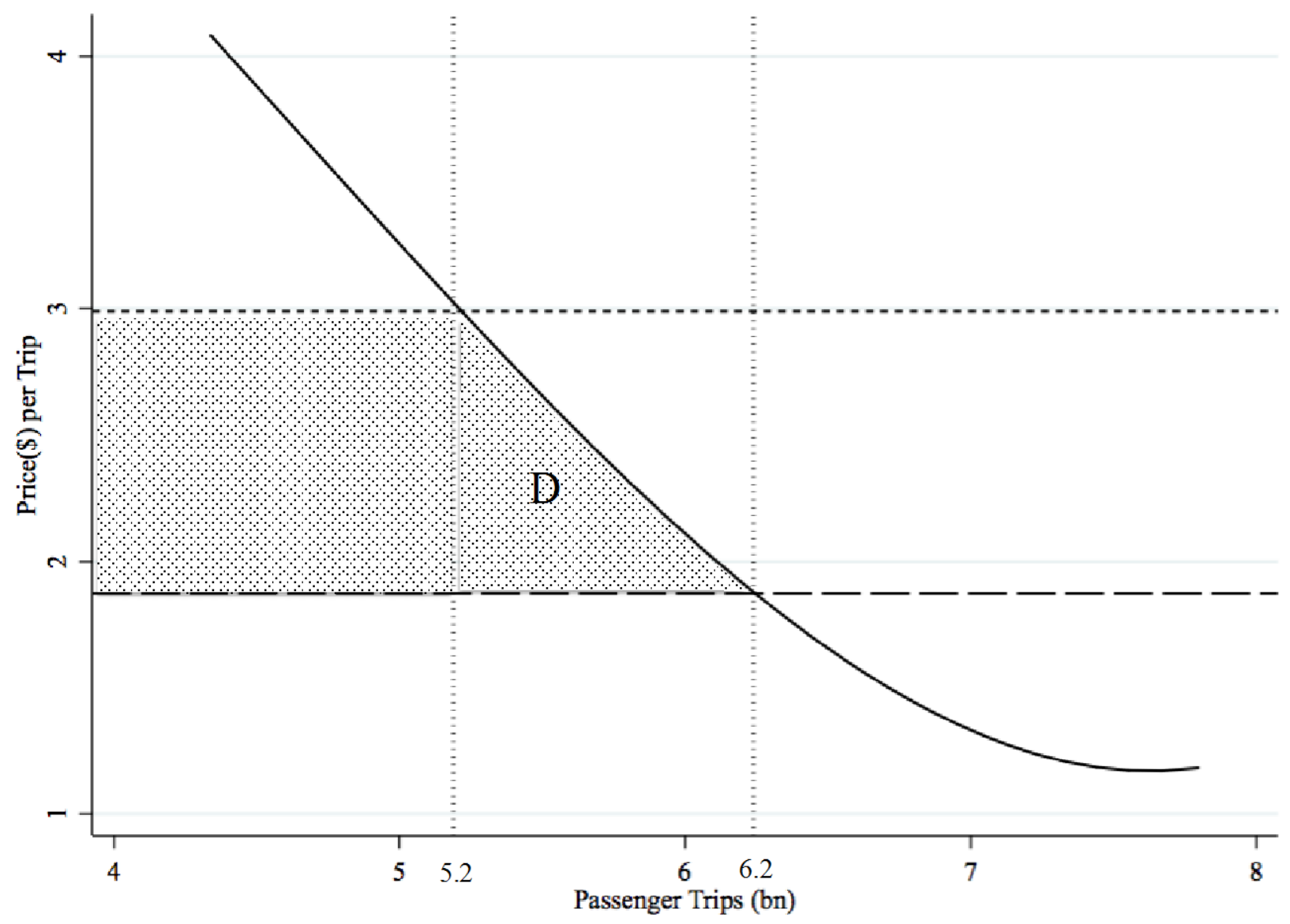

Note: The horizontal dotted line is the supply of passenger trips under 2011 levels of privatization, where $g\left(\alpha_{1}, \hat{p}, u\right)=\$ 3.00$. At this current level of privatization, total passenger trips in 2011 were 5.2 billion. The horizontal dashed line is the supply of passenger trips under the counterfactual scenario of complete privatization, where $g\left(p_{1}, \hat{p}, u\right)=\$ 1.87$. Under the hypothetical scenario, annual passenger trips totals 6.2 billion. The solid black curved line is consumer demand for passenger trips. The shaded area represents the change in consumer welfare when the price of bus transit is at its current inefficiently high level of $\$ 3.00$ per trip. The shaded area corresponds to $A$ in equation (1A) of Appendix 4. Change in US aggregate consumer surplus amounts to $\$ 6.3$ billion. Area D represents the deadweight loss. Aggregate deadweight loss amounts to approximately $\$ 524.3$ million. 
Table 1: Summary Statistics for Top 20 Urbanized Areas (UZA)

\begin{tabular}{|c|c|c|c|c|c|c|c|}
\hline Rank & City & $\begin{array}{l}\text { Total Vehicle } \\
\text { Miles Traveled } \\
\text { (in '000s) }\end{array}$ & $\begin{array}{l}\text { Cost Per } \\
\text { Mile }\end{array}$ & $\begin{array}{c}\text { Privatization } \\
\text { Rate }\end{array}$ & $\begin{array}{c}\text { Avg. Cost } \\
\text { Per Mile in } \\
\text { 1990's }\end{array}$ & $\begin{array}{l}\text { Avg. Cost Per } \\
\text { Mile in 2000's }\end{array}$ & $\begin{array}{c}\text { No. Bus } \\
\text { Transit } \\
\text { Agencies }\end{array}$ \\
\hline 1 & New York, NY & 166,033 & $\$ 18.67$ & $8 \%$ & $\$ 13.38$ & $\$ 16.17$ & 13 \\
\hline 2 & Los Angeles, CA & 148,022 & $\$ 9.20$ & $21 \%$ & $\$ 8.89$ & $\$ 8.21$ & 13 \\
\hline 3 & Chicago, IL & 83,713 & $\$ 11.17$ & $3 \%$ & $\$ 8.93$ & $\$ 10.36$ & 6 \\
\hline 4 & Houston, TX & 38,796 & $\$ 7.49$ & $22 \%$ & $\$ 6.57$ & $\$ 6.44$ & 2 \\
\hline 5 & Philadelphia, PA & 52,569 & $\$ 12.35$ & $2 \%$ & $\$ 10.20$ & $\$ 10.89$ & 3 \\
\hline 6 & Phoenix, AZ & 34,945 & $\$ 6.30$ & $100 \%$ & $\$ 6.58$ & $\$ 6.49$ & 5 \\
\hline 7 & San Antonio, TX & 22,424 & $\$ 5.91$ & - & $\$ 4.33$ & $\$ 5.26$ & 1 \\
\hline 8 & San Diego, CA & 25,415 & $\$ 7.09$ & $63 \%$ & $\$ 5.53$ & $\$ 6.64$ & 3 \\
\hline 9 & Dallas-Fort Worth, TX & 35,649 & $\$ 7.72$ & $0.2 \%$ & $\$ 8.06$ & $\$ 7.50$ & 2 \\
\hline 10 & San Jose, CA & 17,277 & $\$ 12.63$ & $1.3 \%$ & $\$ 9.57$ & $\$ 11.73$ & 1 \\
\hline 11 & Austin, TX & 14,323 & $\$ 7.70$ & $40.9 \%$ & $\$ 5.34$ & $\$ 6.97$ & 1 \\
\hline 12 & Jacksonville, FL & 9,366 & $\$ 6.70$ & $14.9 \%$ & $\$ 5.09$ & $\$ 5.82$ & 1 \\
\hline 13 & San Francisco, CA & 53,308 & $\$ 13.58$ & $12.2 \%$ & $\$ 9.29$ & $\$ 11.65$ & 7 \\
\hline 14 & Indianapolis, IN & 7,369 & $\$ 6.06$ & $5.1 \%$ & $\$ 4.79$ & $\$ 5.70$ & 1 \\
\hline 15 & Columbus, $\mathrm{OH}$ & 11,859 & $\$ 7.15$ & - & $\$ 6.86$ & $\$ 7.61$ & 1 \\
\hline 16 & Charlotte, NC & 12,526 & $\$ 6.31$ & - & $\$ 5.51$ & $\$ 6.07$ & 1 \\
\hline 17 & Detroit, MI & 25,582 & $\$ 8.82$ & $1.1 \%$ & $\$ 7.41$ & $\$ 8.33$ & 2 \\
\hline 18 & El Paso, TX & 7,561 & $\$ 6.12$ & - & $\$ 4.60$ & $\$ 5.53$ & 1 \\
\hline 19 & Seattle, WA & 55,728 & $\$ 10.06$ & $2.2 \%$ & $\$ 7.06$ & $\$ 8.52$ & 5 \\
\hline \multirow[t]{2}{*}{20} & Denver, CO & 40,644 & $\$ 7.42$ & $45.3 \%$ & $\$ 6.46$ & $\$ 6.24$ & 1 \\
\hline & US Average & 28,069 & $\$ 9.25$ & $16 \%$ & $\$ 7.37$ & $\$ 8.27$ & \\
\hline
\end{tabular}

Note: Cities ranked by 2014 population estimate. Total VMT, Cost Per Mile, and Privatization Rate values reported as of 2012. Cost per mile $=$ Total Cost $/$ VMT. Privatization Rate is the ratio of annual VMT operated by a private contractor to total annual VMT. Cost values reported in terms of 2012 real dollars. US Average is weighted by VMT. 
Table 2: Distribution of Cost Per Mile in States with Strong vs. Weak Bargaining Rights PANEL A: All STATES

\begin{tabular}{lcccc}
\hline & 1998 & 2002 & 2007 & 2012 \\
\hline 10th percentile & $\$ 4.39$ & $\$ 4.53$ & $\$ 5.06$ & $\$ 5.00$ \\
25th percentile & $\$ 5.31$ & $\$ 5.49$ & $\$ 6.17$ & $\$ 6.49$ \\
Median & $\$ 6.79$ & $\$ 6.83$ & $\$ 7.69$ & $\$ 7.89$ \\
75th percentile & $\$ 9.14$ & $\$ 8.75$ & $\$ 9.94$ & $\$ 11.05$ \\
90th percentile & $\$ 10.78$ & $\$ 10.63$ & $\$ 13.66$ & $\$ 13.80$ \\
Average & $\$ 7.45$ & $\$ 7.59$ & $\$ 8.55$ & $\$ 9.25$ \\
\hline Observations & 309 & 325 & 370 & 377 \\
Corr(1998 Cost, 2012 Cost) & 0.902 & & \\
\hline
\end{tabular}

PANEL B: WEAK BARGAINING RIGHTS STATES

\begin{tabular}{lcccc}
\hline & 1998 & 2002 & 2007 & 2012 \\
\hline 10th percentile & $\$ 4.15$ & $\$ 4.33$ & $\$ 4.68$ & $\$ 4.82$ \\
25th percentile & $\$ 4.49$ & $\$ 4.94$ & $\$ 5.53$ & $\$ 5.91$ \\
Median & $\$ 5.91$ & $\$ 5.73$ & $\$ 6.27$ & $\$ 6.83$ \\
75 th percentile & $\$ 6.79$ & $\$ 6.31$ & $\$ 6.70$ & $\$ 7.50$ \\
90th percentile & $\$ 6.94$ & $\$ 6.67$ & $\$ 7.51$ & $\$ 7.86$ \\
Average & $\$ 5.74$ & $\$ 5.74$ & $\$ 6.18$ & $\$ 6.61$ \\
\hline Observations & 99 & 107 & 121 & 128 \\
Corr(1998 Cost, 2012 Cost) & & 0.712 & & \\
\hline
\end{tabular}

PANEL C: STRONG BARGAINING RIGHTS STATES

\begin{tabular}{lcccc}
\hline & 1998 & 2002 & 2007 & 2012 \\
\hline 10th percentile & $\$ 4.84$ & $\$ 4.87$ & $\$ 5.37$ & $\$ 5.25$ \\
25th percentile & $\$ 5.82$ & $\$ 6.02$ & $\$ 6.46$ & $\$ 6.70$ \\
Median & $\$ 7.19$ & $\$ 7.84$ & $\$ 8.43$ & $\$ 9.48$ \\
75 th percentile & $\$ 9.66$ & $\$ 10.01$ & $\$ 11.09$ & $\$ 13.18$ \\
90th percentile & $\$ 11.72$ & $\$ 12.34$ & $\$ 14.14$ & $\$ 14.84$ \\
Average & $\$ 8.01$ & $\$ 8.21$ & $\$ 9.34$ & $\$ 10.20$ \\
\hline Observations & 210 & 218 & 249 & 249 \\
Corr(1998 Cost, 2012 Cost) & & 0.900 & & \\
\hline
\end{tabular}

Note: Cost per mile $=$ Total Cost $/$ VMT. Cost values reported in terms of 2012 real dollars. Values are weighted by transit agency annual VMT. 
Table 3: Sample Distribution of Hourly Pay for Full-time Bus Operators

\begin{tabular}{lcccc}
\hline & Boston $^{1}$ & Chicago $^{2}$ & Houston $^{3}$ & Denver $^{4}$ \\
\hline Hourly Wage Distribution & & & & \\
25th percentile & $\$ 37.76$ & $\$ 24.19$ & $\$ 20.12$ & $\$ 16.45$ \\
50th percentile & $\$ 44.29$ & $\$ 32.25$ & $\$ 20.12$ & $\$ 20.00$ \\
75th percentile & $\$ 48.38$ & $\$ 32.25$ & $\$ 22.60$ & $\$ 20.00$ \\
$\quad$ Mean & $\$ 42.89$ & $\$ 29.16$ & $\$ 20.21$ & $\$ 18.56$ \\
No. Employees & 1325 & 4074 & 1343 & 980 \\
Employees per 1000 VMT & 0.05 & 0.07 & 0.03 & 0.02 \\
Transit Agency & MBTA & CTA & MTA & RTD \\
& & & & \\
\hline Urbanized Area Statistics & & & & \\
$\quad$ Share of Unionized Workers & $8.60 \%$ & $8.10 \%$ & $3.20 \%$ & $5.0 \%$ \\
$\quad$ Right to Work State? & No & No & Yes & No \\
Mean Home Price & $\$ 459,744$ & $\$ 322,764$ & $\$ 225,332$ & $\$ 340,703$ \\
& & & & \\
\hline
\end{tabular}

Note: Hourly Pay imputed from reported base pay, assuming 40 hour work weeks for 50 weeks per year. Home prices sourced from ACCRA Cost of Living Index. Share of Unionized workers sourced from CPS.

(1) Data based on 2014 values. Source: http://www.mbta.com/uploadedfiles/

Smart_Forms/News,_Events_and_Press_Releases/Wages2014.pdf

(2) Data based on 2014 values. Source: http://www.transitchicago.com/foia/

(3) Data based on 2014 values.Source: http://salaries.texastribune.org/metropolitan-transit-authority/

(4) Data based on 2012 values. Source: http://www.nataliementen.com/documents/

RTD\%20Salaries\%202012.pdf 
Table 4: Test for Discontinuity in Transit Agency Characteristics Near Winning Margin Threshold

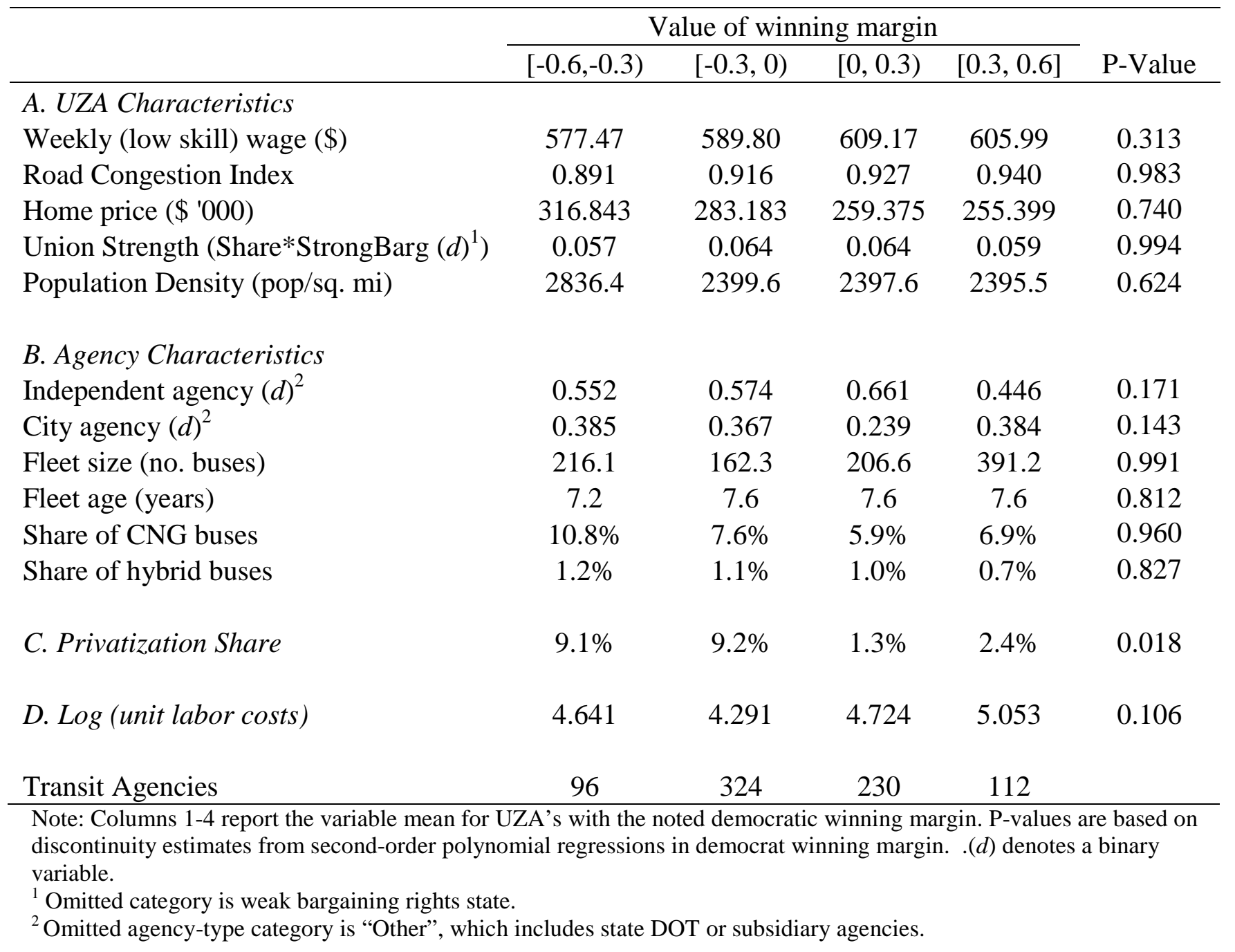


Table 5A: Transit Agency Privatization Share Estimates: Regression Discontinuity Approach

\begin{tabular}{lcccc}
\hline & $(1)$ & $(2)$ & $(3)$ & $(4)$ \\
& OLS & OLS & OLS & LPoly \\
\hline Democrat $(d)^{1}$ & $-0.070^{* *}$ & $-0.060^{* *}$ & -0.010 & $-0.101^{* * *}$ \\
& $(0.034)$ & $(0.029)$ & $(0.039)$ & $(0.036)$ \\
Democrat * StrongBarg $(d)^{2}$ & & & $-0.074^{*}$ & \\
Year \& State FE & & & $(0.043)$ & \\
UZA \& Agency Controls & $\mathrm{Y}$ & $\mathrm{Y}$ & $\mathrm{Y}$ & \\
Robust CCT Confidence Interval & & $\mathrm{Y}$ & $\mathrm{Y}$ & \\
Observations & 1444 & 1444 & 1444 & 549 \\
\hline
\end{tabular}

Note: Dependent variable is privatization share. Includes dominant transit agencies. $(d)$ denotes a binary variable. All regressions include the second-order polynomials of democratic winning margin and their interactions with democratic mayor dummy. UZA \& Agency Controls listed in Table 4. "LPoly" employs local polynomial RD estimation with robust confidence intervals developed by Calonico, Cattaneo and Titiunik (“CCT”) (2014). LPoly estimate uses a triangular kernel and CCT bandwidth selector. Cluster standard errors at the UZA level are in parentheses. ${ }^{*} p<0.10,{ }^{* *} p<0.05$, ${ }^{* * * *} p<0.01$.

${ }^{1}$ Omitted category is Republican mayoral winner.

${ }^{2}$ Omitted category is weak bargaining rights state. 
Table 5B: Transit Agency Labor Cost Per Mile Estimates: Regression Discontinuity Approach

\begin{tabular}{|c|c|c|c|c|c|c|c|}
\hline Privatization share & $\begin{array}{c}-0.365^{* * *} \\
(0.095)\end{array}$ & $\begin{array}{l}\text { ULS } \\
-0.159^{* *} \\
(0.078)\end{array}$ & $\begin{array}{l}\text { GMIVI } \\
-1.919^{* *} \\
(0.886)\end{array}$ & $\begin{array}{l}\text { GIVIVI } \\
-0.447 \\
(0.593)\end{array}$ & $\begin{array}{l}\text { GMM } \\
-2.163^{* *} \\
(0.857)\end{array}$ & $\begin{array}{l}\text { GMM } \\
-1.004^{*} \\
(0.525)\end{array}$ & $\begin{array}{l}-2.126^{* *} \\
(1.029)\end{array}$ \\
\hline $\begin{array}{l}\text { Year \& State FE } \\
\text { UZA \& Agency Controls } \\
\text { Democrat * StrongBarg }(d)\end{array}$ & $\mathrm{Y}$ & $\mathrm{Y}$ & $\mathrm{Y}$ & Y & $\mathrm{Y}$ & $\begin{array}{l}\mathrm{Y} \\
\mathrm{Y} \\
\mathrm{Y}\end{array}$ & \\
\hline $\begin{array}{l}\text { Robust CCT Confidence Interval } \\
\text { Observations } \\
\text { Reduction from } 100 \% \text { privatization }\end{array}$ & $\begin{array}{c}1444 \\
30.9 \%\end{array}$ & $\begin{array}{c}1444 \\
15.0 \%\end{array}$ & $\begin{array}{c}1444 \\
90.1 \%\end{array}$ & $\begin{array}{c}1444 \\
46.4 \%\end{array}$ & $\begin{array}{c}1444 \\
90.2 \%\end{array}$ & $\begin{array}{c}1444 \\
68.1 \%\end{array}$ & $\begin{array}{c}{[-4.145 ;-0.110]} \\
549 \\
93.0 \%\end{array}$ \\
\hline
\end{tabular}

Note: Dependent variable is $\log ($ labor cost per VMT). Includes dominant transit agencies. All regressions control for quadratic polynomial of winning margin and their interaction with democrat mayor indicator. (d) denotes a binary variable. "LPoly" employs local polynomial Fuzzy RD estimation with robust confidence intervals developed by Calonico, Cattaneo and Titiunik (“CCT”) (2014). LPoly estimate uses a triangular kernel and CCT bandwidth selector. UZA \& Agency Controls listed in Table 4. Standard errors clustered at UZA level. ${ }^{*} p<0.10,{ }^{* *} p<0.05,{ }^{* * * *} p<0.01$.

*Because equation (7) takes the semi-logarithmic functional form and the privatization rate ranges from 0 to 1 , a consistent estimator for the percentage impact from full privatization (e.g., privatization going from 0 to 1$)$ on the labor cost is $\left[\exp \left(\hat{\gamma}-\frac{\operatorname{var}(\widehat{\gamma})}{2}\right)-1\right]$. The values in the final row represent the expected cost reduction from an agency going from $0 \%$ privatized operations to $100 \%$. 
Table 6: Full Time Employee Headcount and Union Strength

\begin{tabular}{llll}
\hline & $(1)$ & $(2)$ & $(3)$ \\
& OLS & OLS & OLS \\
\hline Right to Work $(\mathrm{RtW})$ State $(d)^{1}$ & $-0.073^{* * *}$ & $-0.069^{* * *}$ & -0.010 \\
& $(0.010)$ & $(0.013)$ & $(0.019)$ \\
Strong Barg. State $(d)^{2}$ & & 0.006 & $0.056^{* * *}$ \\
& & $(0.013)$ & $(0.017)^{* * *}$ \\
RtW State x Strong Barg State $(d)$ & & & $-0.108^{* *}$ \\
& & & $(0.025)^{* * *}$ \\
Constant & $-2.754^{* * *}$ & $-2.759^{* * *}$ & $-2.802^{* * *}$ \\
& $(0.019)$ & $(0.022)$ & $(0.024)$ \\
\hline Observations & 3395 & 3395 & 3395 \\
$R^{2}$ & 0.012 & 0.012 & 0.017 \\
\hline
\end{tabular}

Note: The dependent variable is the log of full time employee headcount per publicly operated VMT. All regressions are OLS and include year fixed effects. $(d)$ denotes a binary variable. Sample includes subset of transit agencies which reported employee work hours and counts. Standard errors in parentheses. ${ }^{*} p<0.10,{ }^{* *}$ $p<0.05,{ }^{* * *} p<0.01$.

${ }^{1}$ Omitted category is a non-right-to-work state.

${ }^{2}$ Omitted category is a weak bargaining rights state.

Table 7: Effect of Right to Work Laws on Labor Costs using State Borders

\begin{tabular}{lcccc}
\hline & $(1)$ & $(2)$ & $(3)$ & $(4)$ \\
\hline Right to Work State $(d)^{1}$ & $-0.536^{* * *}$ & $-0.397^{* * *}$ & $-0.680^{* * *}$ & $-0.298^{* * *}$ \\
& $(0.052)$ & $(0.048)$ & $(0.017)$ & $(0.054)$ \\
& & & & \\
County Pair FE & $\mathrm{Y}$ & $\mathrm{Y}$ & $\mathrm{Y}$ & $\mathrm{Y}$ \\
Year FE & & & $\mathrm{Y}$ & $\mathrm{Y}$ \\
State FE & & & & $\mathrm{Y}$ \\
UZA \& Agency controls & & & & \\
& 206 & 206 & 206 & 206 \\
Observations & 0.530 & 0.709 & 0.709 & 0.902 \\
$R^{2}$
\end{tabular}

Note: The dependent variable is log(labor cost per VMT). Observations consist of 21 transit agencies in 17 counties that border another state with differing Right to Work legislation. UZA \& Agency Controls listed in Table 4. $(d)$ denotes a binary variable. Standard errors are clustered by transit agency. ${ }^{*} p<0.10,{ }^{* *} p$ $<0.05,{ }^{* * *} p<0.01$.

${ }^{1}$ Omitted category is a non-right-to-work state. 
Table 8: Dominant Transit Agencies Effects on Operating Costs with City-Year Fixed Effects

\begin{tabular}{lcccc}
\hline & $(1)$ & $(2)$ & $(3)$ & $(4)$ \\
\hline Dominant TA (“Dom”) $(d)^{1}$ & $0.275^{* * *}$ & $0.362^{* * *}$ & $0.356^{* * *}$ & $0.268^{* * *}$ \\
& $(0.051)$ & $(0.053)$ & $(0.060)$ & $(0.077)$ \\
Dom x RtW State $(d)^{2}$ & & $-0.338^{* * *}$ & $-0.335^{* * *}$ & $-0.278^{* * *}$ \\
& & $(0.059)$ & $(0.058)$ & $(0.055)$ \\
Dom $(d)$ x UnionShare & & & 0.052 & -0.145 \\
& & & $(0.369)$ & $(0.367)$ \\
Dom x StrongBarg $(d)^{3}$ & & & & $0.116^{* *}$ \\
& 3706 & 3706 & 3706 & 3706 \\
\hline Observations & 0.538 & 0.579 & 0.579 & 0.582 \\
$R^{2}$
\end{tabular}

Note: Dependent variable is $\log ($ operating costs per VMT). The "Dominant" TA has the highest average annual VMT in a given UZA. (d) denotes a binary variable. All regressions include UZA*year fixed effects. Standard errors clustered at UZA level in parentheses. ${ }^{*} p<0.10,{ }^{* *} p<0.05,{ }^{* * *} p<0.01$

${ }^{1}$ Omitted category is non-dominant transit agency.

${ }^{2}$ Omitted category is non-right-to-work state.

${ }^{3}$ Omitted category is a weak bargaining rights state. 
Table 9: Welfare Loss Estimates for Three US Cities in 2011

\begin{tabular}{|c|c|c|c|c|c|c|c|}
\hline City (Agency) & $\begin{array}{c}\text { Current } \\
\text { (Predicted) } \\
\text { Cost / VMT }\end{array}$ & $\begin{array}{c}\text { Privatized } \\
\text { (Predicted) } \\
\text { Cost / VMT }\end{array}$ & $\begin{array}{l}\text { Consumer } \\
\text { Surplus } \\
(\$ 1,000 s)\end{array}$ & $\begin{array}{c}\text { DWL } \\
(\$ 1,000 s)\end{array}$ & $\begin{array}{l}\text { DWL \% } \\
\text { of Public } \\
\text { Funding* }\end{array}$ & $\begin{array}{c}\text { Fleet } \\
\text { Size }\end{array}$ & $\begin{array}{c}\text { Strong } \\
\text { Bargaining } \\
\text { Rights? }\end{array}$ \\
\hline Boston (MBTA) & $\$ 13.59$ & $\$ 8.13$ & $\$ 163,681.72$ & $\$ 14,766.31$ & $1.7 \%$ & 876 & Yes \\
\hline Chicago (CTA) & $\$ 11.29$ & $\$ 6.64$ & $\$ 297,820.21$ & $\$ 26,310.57$ & $3.7 \%$ & 1781 & Yes \\
\hline San Antonio (VIA) & $\$ 7.18$ & $\$ 4.22$ & $\$ 59,607.00$ & $\$ 4,194.99$ & $2.5 \%$ & 446 & No \\
\hline US Total & $\$ 6.63$ & $\$ 4.16$ & $\$ 6,319,339.33$ & $\$ 524,345.60$ & & & \\
\hline
\end{tabular}

Note: Predicted values for Current Cost/VMT and privatized Cost/VMT generated using the RD regression specification. The dependent variable is total operating costs per VMT. Regression controls include all those listed in Table 4 with the addition of city-average diesel and natural gas prices. Privatized Cost/VMT counterfactual assumes privatization share is $100 \%$. $\Delta$ Consumer Surplus and DWL correspond to Areas A and D in Figure 7, respectively.

*Sources: MBTA Fiscal 2012 Audited Financial Statements Pg 5, Net Nonoperating revenue (http://mbta.com/uploadedfiles/About_the_T/Financials/113990_12_MBTA_FS-FINAL.pdf); CTA President's 2012 Budget Recommendations, 2011 Forecasted Total Public Funding Pg 22,

(http://www.transitchicago.com/assets/1/finance_budget/2012_Budget_Book_for_Web.pdf); VIA 2012 Comprehensive Annual

Financial Report; Sept 30, 2012 Pg. 45, Sales Taxes + Grants Reimbursement

(http://www.viainfo.net/Organization/Docs/2012CAFR.pdf) 


\section{Web APPENDIX 1: Labor and Energy Cost Calculations}

We calculated fuel costs using reported fuel-use data from NTD and estimates of retail fuel prices for each of the reported fuel inputs. Fuel prices were sourced from the U.S. Energy Information Administration. Most of our fuel price data vary by state and year. NTD does not report employee headcount outsourced operations. Thus, we infer labor costs as the residual operating costs net of our calculated energy costs. The following figure shows the breakdown of line items included in operating expenses as reported by transit agencies to NTD. Vehicle operating costs include: labor costs (including salaries, wages, benefits, and pensions), costs of fuel, materials and supplies, utility costs, taxes, and liability costs. With the exception of fuel inputs, we cannot separately identify these costs from total operating costs. Thus, our estimate of labor costs is an upward bound, and includes expenses for materials and miscellaneous expenses.

Figure: Operating Costs Line Items as Reported to NTD

\section{Urban Reporting Manual}

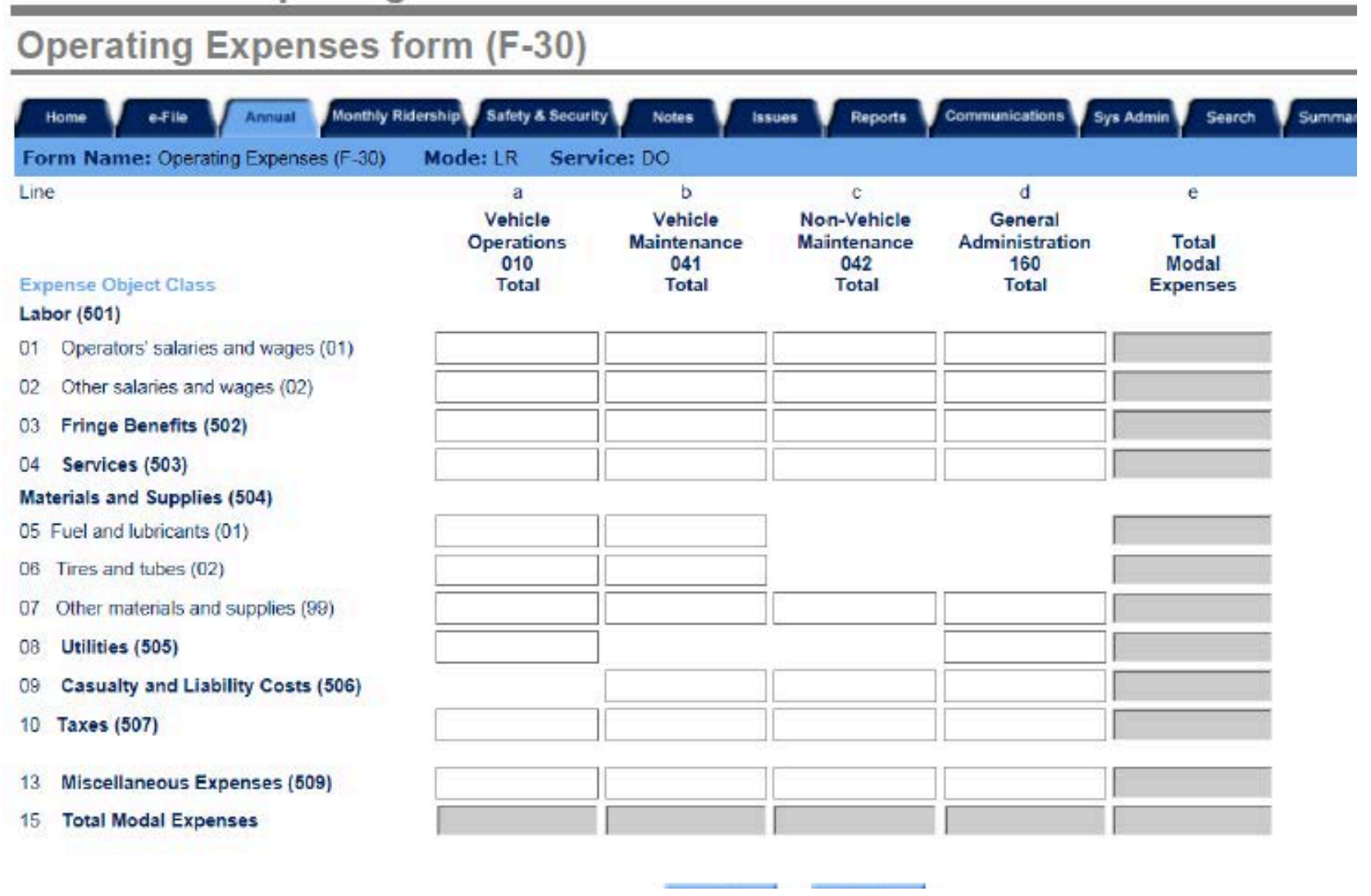

Source: NTD.gov:

http://www.ntdprogram.gov/ntdprogram/pubs/ARM/2013/pdf/4_Financial_Module.pdf 


\section{Web APPENDIX 2: Alternative Empirical Strategies as Robustness Checks}

In this section, we present three alternative empirical strategies based on different identifications from that in the RD analysis. The analysis all provides similar results to those from the RD analysis..

\section{An Instrumental Variables Approach}

We use the IV approach as an alternative to the RD analysis in identifying the causal effect of privatization. We seek instruments that are correlated with a transit agency's share of privatized bus miles but are uncorrelated with the unobserved determinants of bus operating costs. A plausible variable that satisfies these conditions is the interaction between a Bartik measure of state employment growth and a city’s average cost of housing. Following Bartik (1991), we create a state-level employment growth instrument by calculating the annual national employment growth rate for each 6-digit NAICS industry and then weighting this by each state's share of each industry's employment in $1998 .^{32}$ The Bartik employment variable is constructed at the state level rather than at the local level because local economic indicators are more likely to be endogenous to transit agency's operating costs. It captures the heterogeneous effect of national employment shocks (e.g., due to trade) across different states due to their pre-existing conditions (e.g., industry structure). This is unlikely to be correlated with shocks that affect bus operation in a transit agency.

In our regressions, we include the home price as an explanatory variable to control for differences in cost-of-living, which could affect labor cost. We interact the Bartik variable with the city average housing price to introduce cross-city variation. In addition, this interaction captures how a state's economic condition affects privatization decisions differently across cities with different housing prices, and hence different local tax bases. We conjecture that lower employment growth (i.e., a tight state budget) would impact cities with a low home price (less robust local tax base) more severely, and hence induce more privatization. This conjecture is confirmed in our first stage regressions in the Appendix Table 2A. In the regression analyses, standard errors are clustered at the UZA level to account for autocorrelation across transit agencies operating within the city.

\footnotetext{
321998 is selected as the base year because it is the first year in our study and because 1998 was the first year that the NAICS codes were introduced.
} 
The first stage results of the IV regression are shown in Appendix Table 2A. The excluded instrument is the state-level Bartik labor shock measure interacted with UZA-average housing prices, (Bartik IV *Home Price). The instrument has a negative and significant correlation with privatization share, which is robust to the inclusion of observables. Column (3) uses the sample of dominant transit agencies used in the RD analysis. The effect of the Bartik home price instrument on privatization levels is a similar magnitude to that of the full sample estimates. Transit agencies that experience exogenous negative (positive) labor demand shocks in cities with lower (higher) housing prices are more (less) likely to privatize their bus mile operations. This result is consistent with our prediction that agencies in cities with a lower tax base, particularly those in states that are exogenously budget constrained due to poor economic climate, are more likely to seek out public-private partnerships as a means to cut costs.

Labor cost estimates are shown in Appendix Table 2B. The OLS specifications in columns (1) - (2) indicate a 1 percent increase in an agency's share of privatized miles are correlated with a decrease in labor costs per mile ranging from 0.22 to 0.31 percent. Columns (3) - (5) instrument for the privatization share using the state-level Bartik labor shock measure interacted with UZA-average housing prices. Column (5) uses the regression discontinuity sample of only dominant transit agencies. The estimated effect of increasing the privatization share by 1 percent ranges from 0.46 to 1.2 percent reduction in labor costs per mile. The coefficients listed in Appendix Table 2B are close in magnitude to that of the regression discontinuity estimates in Table 5B, and all fall into the CCT robust confidence interval (Table $5 \mathrm{~B}$, column 7). The overall reduction in per-mile labor costs induced by an agency going from no privatization to 100 percent ranges from 38 to 77 percent under the GMM estimators. While the $\mathrm{RD}$ sample estimate is less precisely estimated than that of the full sample, the larger anticipated cost savings from the RD sample reflect that dominant transit agencies are large agencies by definition, so the potential gains from privatizing are more substantial for these large urban agencies, relative to smaller agencies operating in more remote locations. These large costsaving estimates also reflect the fact that the dominant agencies are less likely to privatize, even though the payoffs to doing so are large. In Appendix Table 2A column 2, the dominant transit agency indicator is negatively correlated with privatization levels. At least part of the reason for this tendency for dominant agencies to avoid privatizing is due to strategic actions on the part of 
unions. In section 6.4, we discuss evidence that unions focus their bargaining power on the dominant agencies in a given UZA.

\section{Union Contract Cycle as Instrument}

We carry out estimation of equation (7) and instrument for the privatization share using union contract cycle schedules for 10 transit agencies. When a union's labor contract is over and up for negotiation, the transit agency manager may find it easier to privatize a portion of their operations to private contractors. However, the status of the labor contract (whether it is active or not) should not be correlated with a transit agency's unit labor costs. Appendix Table 5A shows the first stage results. The end of a labor contract cycle is positively correlated with privatization share, as we would expect. Appendix Table 5B shows the impact of privatization on labor costs under OLS and GMM employing the contract cycle instrument. The cost saving estimates are very similar in magnitude to the RD and IV methods discussed in Section 6; a 1\% increase in the share of bus miles that are privatized reduces labor costs per mile by between 0.6 and $0.9 \%$.

\section{Using Subway Cities as Controls}

Due to data limitations, we are unable to employ city-level fixed effects in our main specifications discussed in Section 6. Thus, our identification comes from variation in transit agencies within the same state with differing levels of privatized bus miles. The analyses in Section 6 include various controls for transit agency characteristics, such as fleet size, type, and the share of buses that use alternative fuel. However, it is possible that certain unobservable cityspecific factors affect both privatization decisions and unit labor costs, and these unobservables generate the differences we observe across agencies within the same state.

To address this endogeneity concern, we look at the subset of agencies in our NTD data who’s UZA also has a subway system. Subway systems, by their nature as massive public works projects, are public entities and cannot be privatized. Comparing the operating costs of bus transit to the operating costs of subway transit in the same city will fully control for any citywide unobserved effects that impact transit costs, which may confound our main cross-city identification. We carry out two specifications: in column (1) of Appendix Table 6 the dependent variable is the log of bus operating costs per VMT, and the regression controls for subway operating costs per VMT. In column (2), the dependent variable is the log of the ratio of bus to subway operating costs. Under both specifications, privatization is associated with a 1 percent 
decrease in operating costs per VMT. These results are again, consistent with those found in Section 6 under the RD and IV methods.

\section{Web APPENDIX 3. Heterogeneous Treatment Effects of Privatization}

We examine the heterogeneous treatment effect of privatization. Appendix Table 7 shows estimation results of the effect of privatization share on per-mile labor costs, accounting for the interaction of the privatization share and state bargaining strength, and the interaction of privatization share and transit agency size. We use the size of a transit agency's fleet (number of buses) to measure their size. The first column employs OLS. Each interaction term is negative and statistically significant, implying that privatization reduces labor costs to a larger degree if the transit agency operates in a UZA where unions have stronger legal bargaining power, or if the transit agency serves a larger population. The magnitudes on the privatization share estimate relative to the heterogeneous effect estimates suggest that cost savings realized from privatizing may be washed out by the effects of strong collective bargaining rights for a large transit agency.

The second column in Appendix Table 7 employs the instrumental variable approach discussed in Appendix 2. After instrumenting for privatization share with the Bartik-home price instrument, the effect of privatization on cost savings increases in magnitude for states with strong bargaining rights, and for larger transit agencies. These results are consistent with the discontinuity graphs shown in Figure 5: the difference across agencies with democrat versus a republican mayoral winner in their likelihood of privatizing transit operations is larger for two such agencies in a strong bargaining rights state relative to a weak bargaining rights state. Because of this differential in the propensity to privatize, agencies in strong bargaining rights states observe larger cost savings from privatizing their operations relative to those in weak bargaining rights states, where the opportunity costs are lower. 


\section{Web APPENDIX 4: Details About the Welfare Analysis Calculations}

The procedure we use to estimate welfare loss from high public transit cost is as follows: We begin by specifying the consumer compensating variation obtained from reducing bus transit operating costs by privatizing.

Consider the consumer's minimum cost of achieving a utility level, $u$, given prices $p$ :

$$
g(p, u)=\min _{\{x\}}\{p \cdot x \mid u(x) \geq u\}
$$

The compensated demand function for good $x_{i} \in x$ is given by ${ }^{33}$ :

$$
x_{i}=\frac{\partial g(p, u)}{\partial p_{i}}=g_{i}(p, u)
$$

(Glaister (1974)). Let $\alpha_{1}$ and $p_{1}$ be the price of bus fare under current privatization levels (where majority of bus transit is publicly operated), and under the counterfactual scenario of complete privatization, respectively. Let all other prices faced by the consumer, $\hat{p}$, be held constant. The loss to the consumer from purchasing bus fare, $x_{1}$, at $\alpha_{1}$ instead of the lower efficient price $p_{1}$ can be expressed by:

$$
A=\int_{p_{1}}^{\alpha_{1}} g_{1}(z, \hat{p}, u) d z=g\left(\alpha_{1}, \hat{p}, u\right)-g\left(p_{1}, \hat{p}, u\right)^{34}
$$

The area $A$ is the change in consumer surplus due to the change in transit operating costs.

To apply this theoretical framework to our empirical analysis, we specify $g($.$) as the$ transit agency supply curve. We have posited a Leontief production function whereby transit agencies employ inputs in fixed proportions to produce a bus mile. Thus, marginal costs are equal to unit operating costs, $\frac{C}{V M T}$. Let the transit agency supply curve equal their marginal costs, thus $g()=.\frac{C}{V M T}$. The consumer's expenditure for bus transit is proportional to the transit agency's marginal costs of providing bus service.

\footnotetext{
${ }^{33}$ The difference between the compensated and Marshallian demand function is the income effect. Deaton (1974) shows that if the utility function is additively separable, and the expenditure on the good is a small fraction of income, then the compensated and uncompensated elasticities will be close. For purposes of this exercise, we posit that bus transit is additively separable to all other consumption goods and services.

${ }^{34}$ Rosen and Small (1981) provide a detailed outline for the theoretical justification for measuring price-induced utility changes as areas to the left of the relevant compensated demand curves.
} 
In addition to a supply curve, the other inputs necessary to calculate welfare loss include a demand curve for bus transit, a base unit cost of transit, and the counterfactual unit cost of transit under complete privatization. Our base unit cost of transit is the operating costs per VMT, $\frac{C}{V M T}$, predicted by our model under privatization levels observed as of 2011 . We predict $\frac{C}{V M T}$ under current privatization using the regression discontinuity design specification discussed in Section 6.3. To generate the estimates, we regress the log of total operating costs per VMT on predicted privatization share (city mayoral party affiliation instruments for privatization share in the fuzzy RD design), following the right-hand-side of equation (7). Since we are interested in predicting total operating costs, rather than labor operating costs, we control for energy input prices in addition to each of the covariates impacting labor unit costs presented in Table 4. Under 2011 observed privatization levels, the predicted average $\frac{C}{V M T}$ is $\$ 6.74$. The counterfactual $\frac{C}{V M T}$ predicted by our model if all transit agency operations are completely privatized is approximately $\$ 3.09 .^{35}$

We calculate a demand curve for bus transit using an elasticity measure of bus ridership, or passenger trips, with respect to bus fare. According to Gagnepain \& Ivaldi (2002), Oum, Waters, \& Young (1992), and TRCP Report 95 (2004)) this elasticity measure is approximately -0.4. Specifically, $E_{R}=-0.4=\frac{\% \Delta \text { Ridership }}{\% \Delta \text { Fare }}$. Given the aggregate ridership of bus transit in 2011 was approximately 5.1 billion, we can solve for the change in ridership given an incremental change in bus transit fare. This requires that we specify a transformation from our predicted unit operating costs to bus passenger fare. ${ }^{36}$

To perform this transformation, we multiply the predicted $\frac{C}{V M T}=\$ 6.74$ by the average VMT per passenger trip observed in 2011, 0.28, to calculate predicted unit cost per passenger

\footnotetext{
${ }^{35}$ As our dependent variable is in log form, we calculate the predicted unit cost values using a smearing adjustment following Greene (1951): $\hat{y}=\exp \left(X^{\prime} \hat{\beta}+\frac{\sigma}{2}\right)$

${ }^{36}$ We have characterized transit agency supply in terms of VMT, while consumer demand is in terms of passenger trips. Transit agency costs and revenues are driven by two different output variables that are closely related. Outputs from the perspective of the transit agency are VMT, whereas the passenger uses VMT as inputs in the "production" of their final consumption good, which is passenger miles or passenger-trips. ("This characterization of transit output is quite useful if we construct a general equilibrium model of transit, in which transit firms supply intermediate-type outputs while passengers, who demand them, generate final-type outputs.” Berechman (1993)). Prior literature has frequently employed similar transformations as those discussed here, recognizing the difference between VMT as intermediate output and passenger trips as final output in transit systems (Gagnepain \& Ivaldi (2002).
} 
trip, $\frac{C}{\text { Trip }}$. This implies bus passengers traveled an average of 3.5 miles per trip in 2011. By employing a constant term, $\frac{C}{\text { Trip }}$, for the transformation of predicted unit costs, we assume the number of passenger trips per VMT is unaffected by privatization levels. This static assumption is consistent with Gagenpain and Ivaldi (2002) who modeled the relationship between VMT and passenger trips as a reduced form function of population characteristics, density, and road congestion in a particular year. Since our welfare analysis is particular to the year 2011, our methodology is consistent with Gagenpain and Ivaldi (2002) in assuming that the relationship between capacity and demand is static in a particular year. Our empirical analyses on the impacts of privatization on transit agency VMT and ridership (passenger miles/VMT) further support this simplification. Appendix Table 3 shows that privatization does not have a deterministically significant impact on either VMT or occupancy rate.

Our transformation further assumes transit agencies price at marginal cost. In this way we can interpret unit cost per passenger trip as an approximation to the predicted bus fare per passenger trip. We acknowledge that marginal cost pricing is not representative of public transit pricing schemes. Public transit pricing is, in general, heavily subsidized to make up for the large fixed costs of infrastructure. Mohring (1972) gives a detailed discussion of dynamic optimal pricing schemes. We abstract away from identifying the pricing scheme of transit agencies in order to highlight general welfare effects from inefficient public transit. In summary:

$$
\begin{aligned}
& g\left(\alpha_{1}, \hat{p}, u\right)=\$ 6.74 * 0.28=\$ 1.89 \text { per trip } \\
& g\left(p_{1}, \hat{p}, u\right)=\$ 3.09 * 0.28=\$ 0.87 \text { per trip } \\
& \% \Delta \text { Ridership }=\% \Delta \text { Cost per Trip } * E_{R}
\end{aligned}
$$

where $\% \Delta$ Cost per Trip are based on incremental value changes between $\$ 0.87$ and $\$ 1.89$. We calculate the area $A$ in equation (1A) using the trapezoidal method. $A$ in equation (1A) corresponds to the shaded area in Figure 7.

The procedure for calculating welfare loss specific to Boston, Chicago, and San Antonio mimic the above discussion with the following exceptions. First, rather than using an aggregate ridership value of 5.1 billion, the base ridership value is based on city-specific estimates. Second, the transformation calculations employ the city-specific average VMT per passenger trip observed in 2011. These values and their sources are shown in the following table: 
City Transit Agency Values as of 2011

\begin{tabular}{lccc}
\hline City (Agency) & $\begin{array}{c}\text { Total Annual } \\
\text { Passenger Trips } \\
(\mathrm{mn} .)\end{array}$ & $\begin{array}{c}\text { Total Annual } \\
\text { VMT (mn.) }\end{array}$ & $\begin{array}{c}\text { VMT/Passenger } \\
\text { Trip }\end{array}$ \\
\hline Boston (MBTA) & 109.9 & 27.2 & 0.25 \\
Chicago (CTA) & 310.4 & 58.0 & 0.19 \\
San Antonio (VIA) & 44.2 & 22.4 & 0.51 \\
\hline Source: NTD.gov Data Tables, Table 19: Transit Operating Statistics for 2011
\end{tabular}


Appendix Figure 1: Selected baseline UZA characteristics at the Democratic winning margin threshold. Sample includes 1,444 UZA - year pairs. Bin size $=0.05$.

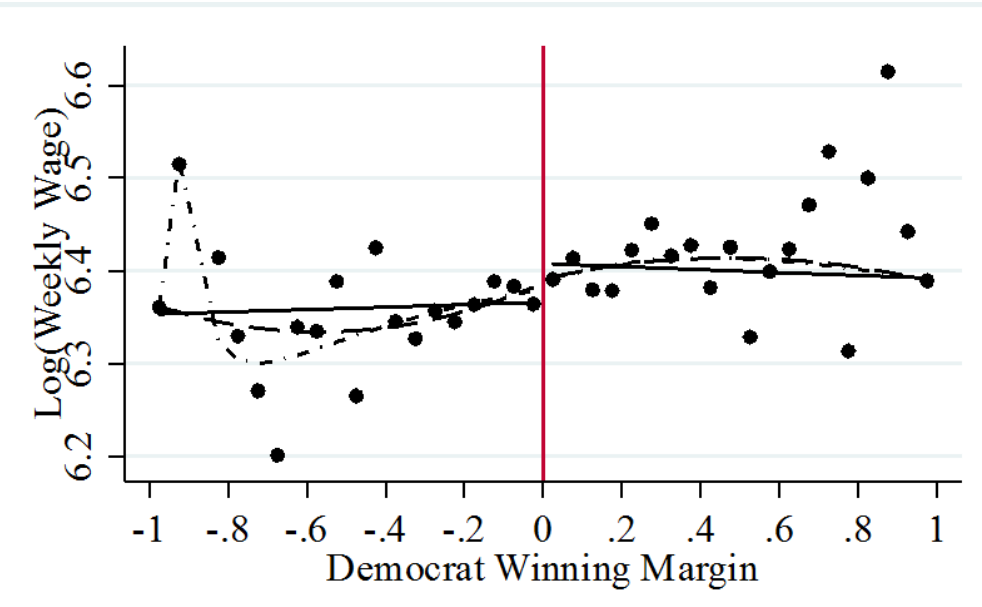

- Linear fit- - - Quadratic fit' - - Cubic fit

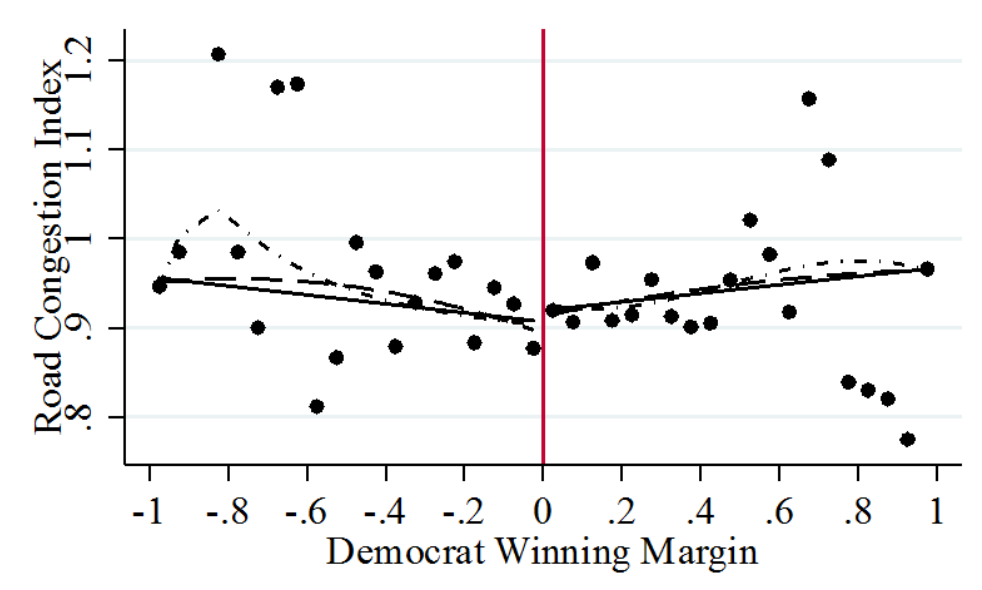

- Linear fit $--\cdot$ Quadratic fit $-\cdot-$ Cubic fit

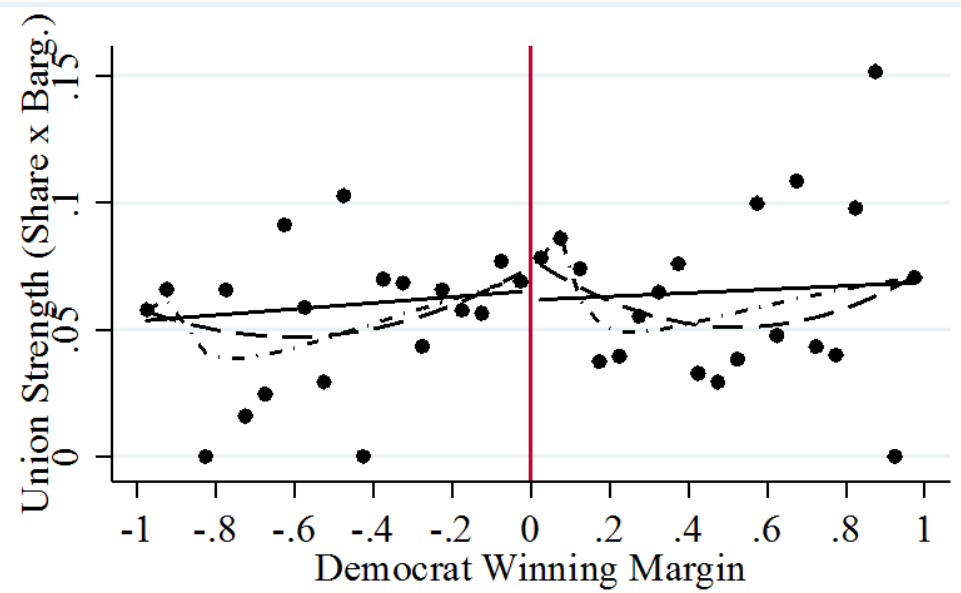

Linear fit- - - Quadratic fit' - - Cubic fit

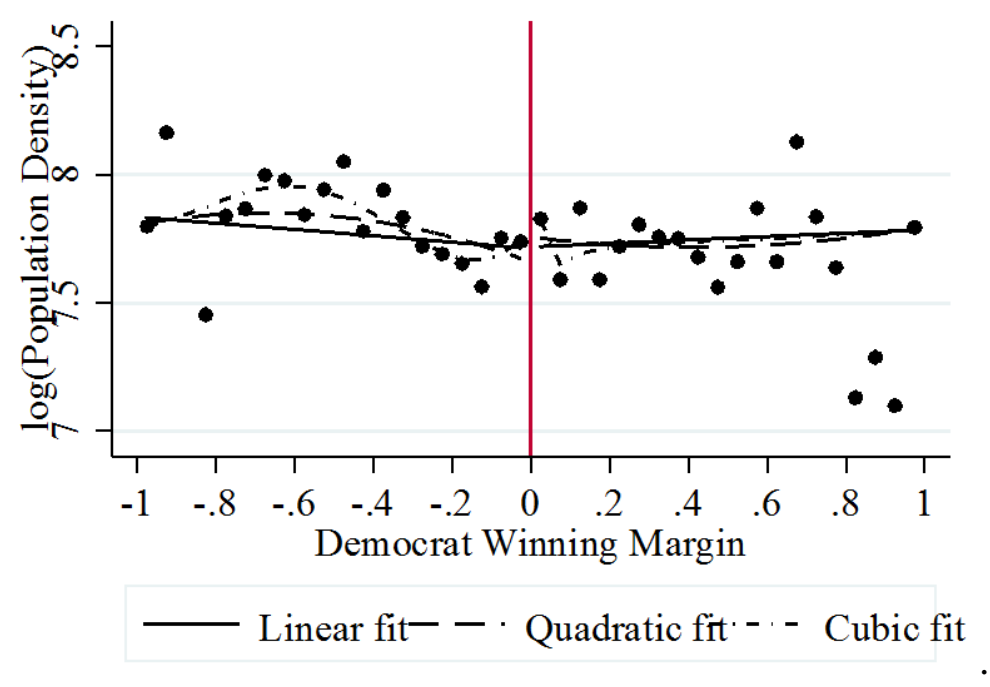


Appendix Figure 2: Privatization share among non-dominant agencies

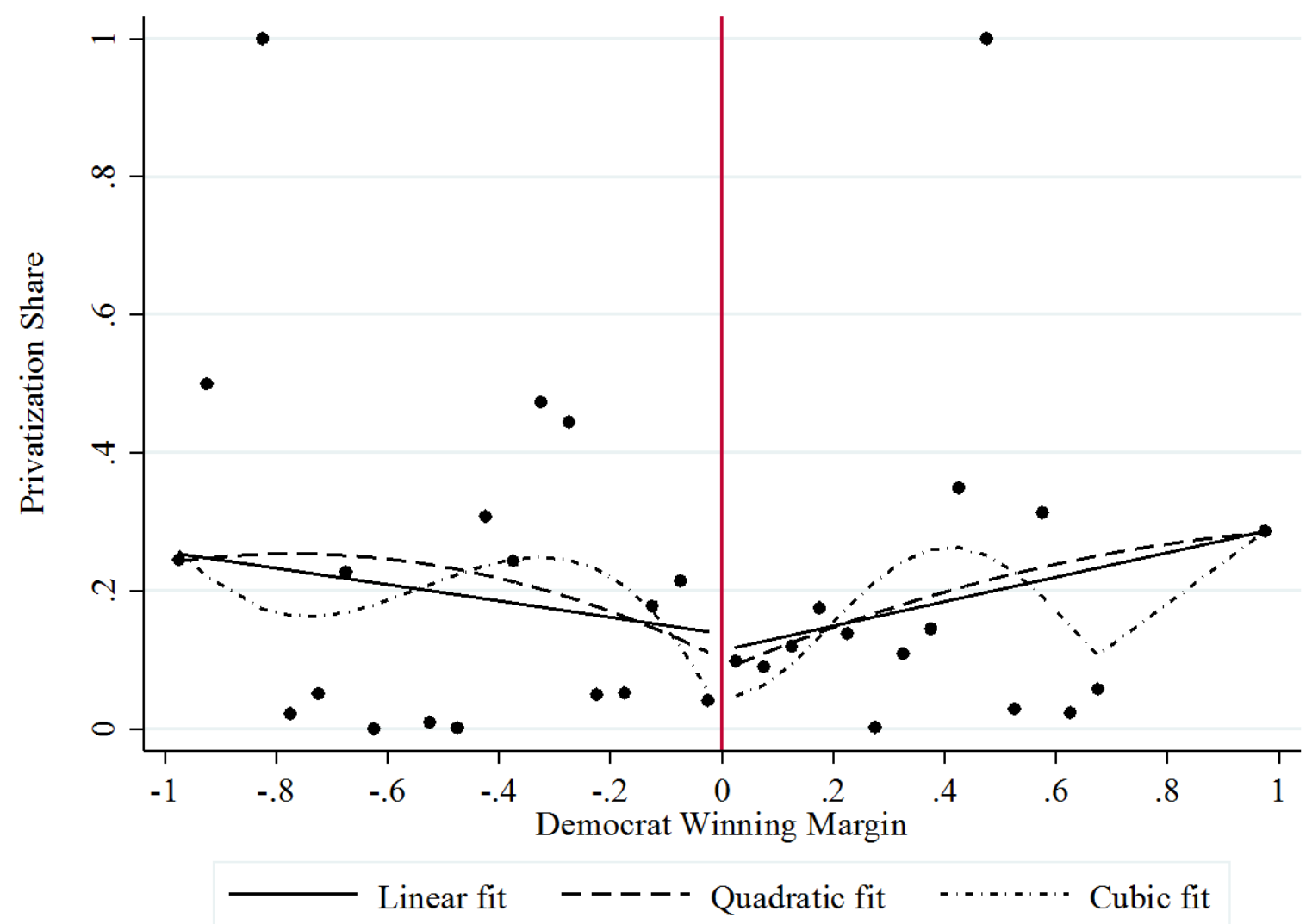

Note: Sample includes 662 transit agency-year observations. "Non-dominant" agencies include those that do not have the largest average annual vehicle miles traveled from 1998-2011 in a UZA. Bin size = 0.05. 
Appendix Figure 3: Privatization Share at the Democratic winning margin threshold for window of $60 \%$. Bin size=0.05

A. Full Sample (762 obs.)
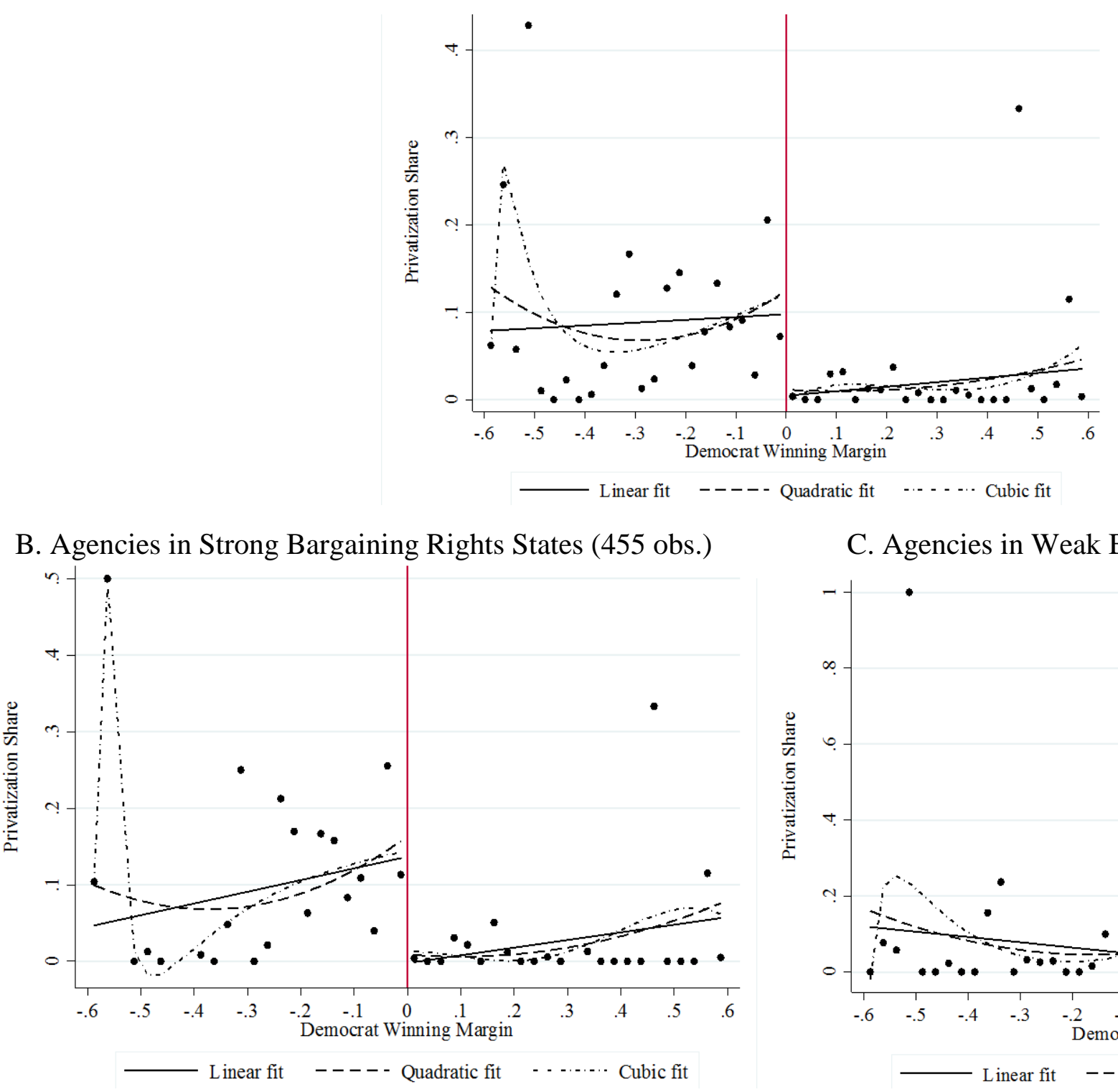

C. Agencies in Weak Bargaining Rights States (307 obs.)

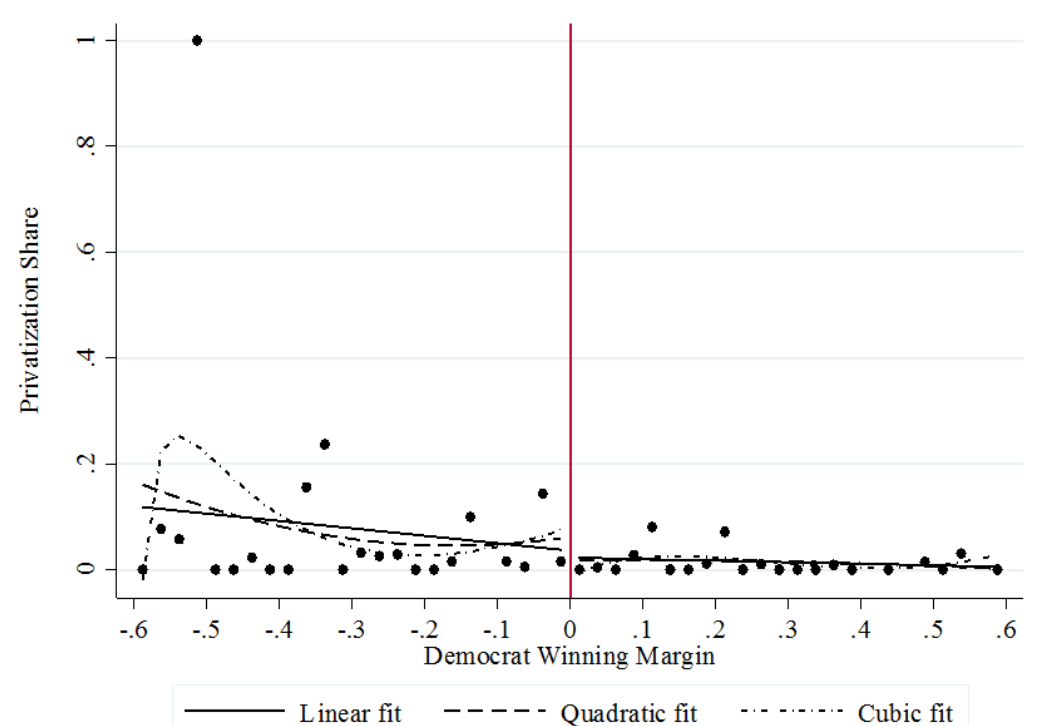


APPENDIX TABLE 1: Labor Cost, Varying Windows around Threshold

\begin{tabular}{|c|c|c|c|c|c|c|c|}
\hline & $\begin{array}{c}(1) \\
{[-0.7,0.7]}\end{array}$ & $\begin{array}{c}(2) \\
{[-0.6,0.6]}\end{array}$ & $\begin{array}{c}(3) \\
{[-0.5,0.5]}\end{array}$ & $\begin{array}{c}(4) \\
{[-0.4,0.4]}\end{array}$ & $\begin{array}{c}(5) \\
{[-0.3,0.3]}\end{array}$ & $\begin{array}{c}\mathbf{( 6 )} \\
{[-0.2,0.2]}\end{array}$ & $\begin{array}{c}(7) \\
{[-0.1,0.1]}\end{array}$ \\
\hline \multicolumn{8}{|l|}{ A. OLS Results } \\
\hline Priv. share & $\begin{array}{c}-0.235^{* * *} \\
(0.059)\end{array}$ & $\begin{array}{c}-0.244^{* * *} \\
(0.063)\end{array}$ & $\begin{array}{c}-0.252^{* * *} \\
(0.066)\end{array}$ & $\begin{array}{c}-0.271^{* * *} \\
(0.065)\end{array}$ & $\begin{array}{c}-0.272^{* * *} \\
(0.071)\end{array}$ & $\begin{array}{c}-0.283^{* * *} \\
(0.082) \\
\end{array}$ & $\begin{array}{c}-0.448^{* * *} \\
(0.103)\end{array}$ \\
\hline \multicolumn{8}{|l|}{ B. Fuzzy RD Results } \\
\hline Priv. share & $\begin{array}{l}-0.817 \\
(0.667)\end{array}$ & $\begin{array}{c}-1.023 \\
(0.695)\end{array}$ & $\begin{array}{l}-2.431 \\
(1.518)\end{array}$ & $\begin{array}{l}-3.509 \\
(2.885)\end{array}$ & $\begin{array}{l}-3.457 \\
(3.201)\end{array}$ & $\begin{array}{l}-3.144 \\
(3.298)\end{array}$ & $\begin{array}{c}-9.770 \\
(21.751)\end{array}$ \\
\hline \multicolumn{8}{|c|}{ C. Fuzzy RD Results with Democrat*StrongBarg } \\
\hline Priv. share & $\begin{array}{l}-1.177^{*} \\
(0.697)\end{array}$ & $\begin{array}{l}-1.234^{*} \\
(0.721)\end{array}$ & $\begin{array}{l}-3.099^{*} \\
(1.795)\end{array}$ & $\begin{array}{l}-3.144^{*} \\
(1.606)\end{array}$ & $\begin{array}{l}-2.571^{* *} \\
(1.234)\end{array}$ & $\begin{array}{c}-2.630 \\
(1.752)\end{array}$ & $\begin{array}{l}-2.907 \\
(2.601)\end{array}$ \\
\hline Year \& State FE & $\mathrm{Y}$ & $\mathrm{Y}$ & $\mathrm{Y}$ & $\mathrm{Y}$ & $\mathrm{Y}$ & $\mathrm{Y}$ & $\mathrm{Y}$ \\
\hline UZA \& Agency Controls & $\mathrm{Y}$ & $\mathrm{Y}$ & $\mathrm{Y}$ & $\mathrm{Y}$ & $\mathrm{Y}$ & $\mathrm{Y}$ & $\mathrm{Y}$ \\
\hline Obs. & 804 & 762 & 702 & 648 & 554 & 425 & 256 \\
\hline \multicolumn{8}{|c|}{ D. Local Polynomial (CCT) Results } \\
\hline Priv. share & $\begin{array}{l}-2.284^{*} \\
(1.248)\end{array}$ & $\begin{array}{l}-2.285^{*} \\
(1.366)\end{array}$ & $\begin{array}{l}-2.350 \\
(1.497)\end{array}$ & $\begin{array}{c}-2.341 \\
(1.480)\end{array}$ & $\begin{array}{c}-7.604 \\
(14.462)\end{array}$ & $\begin{array}{l}-2.754 \\
(4.053)\end{array}$ & $\begin{array}{c}0.088 \\
(1.454)\end{array}$ \\
\hline Obs. & 445 & 420 & 386 & 386 & 264 & 207 & 126 \\
\hline
\end{tabular}

Note: Dependent variable is $\log ($ labor cost per VMT). Includes dominant transit agencies. All regressions include the second-order polynomials of democratic winning margin and their interactions with democratic mayor dummy. Panel B uses only the democratic mayor discontinuity in the first stage. Panel C uses both the democratic mayor as well as its interaction with Strong Bargaining Rights State indicator to account for heterogeneous discontinuity effects in the first stage. Panel D employs local polynomial RD estimation with robust confidence intervals developed by Calonico, Cattaneo and Titiunik ("CCT") (2014). Panel D estimate use a triangular kernel and CCT bandwidth selector. UZA \& Agency Controls listed in Table 4. Cluster standard errors at the UZA level are in parentheses. ${ }^{*} p<0.10$, $^{* *} p<0.05$, ${ }^{* * *} p<0.01$ 
APPENDIX TABLE 2A: Transit Agency Privatization Share Estimates: First Stage of the IV Approach

\begin{tabular}{|c|c|c|c|}
\hline & $\begin{array}{c}\text { (1) } \\
\text { OLS }\end{array}$ & $\begin{array}{c}\text { (2) } \\
\text { OLS }\end{array}$ & $\begin{array}{c}\text { (3) } \\
\text { OLS }\end{array}$ \\
\hline Bartik IV*Home Price & $\begin{array}{c}-0.396^{* * *} \\
(0.147)\end{array}$ & $\begin{array}{c}-0.345^{* * * *} \\
(0.120)\end{array}$ & $\begin{array}{l}-0.222^{*} \\
(0.134)\end{array}$ \\
\hline Ln (Weekly low skill wage) & & $\begin{array}{l}0.184^{* *} \\
(0.079)\end{array}$ & $\begin{array}{c}0.142 \\
(0.112)\end{array}$ \\
\hline Road congestion index & & $\begin{array}{c}-0.379^{* * * *} \\
(0.133)\end{array}$ & $\begin{array}{c}-0.364 \\
(0.150)\end{array}$ \\
\hline House Price & & $\begin{array}{c}-0.004 \\
(0.015)\end{array}$ & $\begin{array}{c}-0.018 \\
(0.019)\end{array}$ \\
\hline Union share*StrongBarg $(d)^{1}$ & & $\begin{array}{c}0.470 \\
(0.318)\end{array}$ & $\begin{array}{c}0.693 \\
(0.540)\end{array}$ \\
\hline Ln(population density) & & $\begin{array}{c}0.101 \\
(0.063)\end{array}$ & $\begin{array}{l}0.214^{* *} \\
(0.084)\end{array}$ \\
\hline Dominant TA $(d)^{2}$ & & $\begin{array}{c}-0.143^{* * *} \\
(0.048)\end{array}$ & \\
\hline Independent agency $(d)^{3}$ & & $\begin{array}{c}0.021 \\
(0.049)\end{array}$ & $\begin{array}{c}0.049 \\
(0.094)\end{array}$ \\
\hline City agency $(d)^{3}$ & & $\begin{array}{c}0.041 \\
(0.056)\end{array}$ & $\begin{array}{c}0.054 \\
(0.114)\end{array}$ \\
\hline Ln(number of buses) & & $\begin{array}{c}-0.002 \\
(0.015)\end{array}$ & $\begin{array}{l}-0.021 \\
(0.021)\end{array}$ \\
\hline Ln(average bus age) & & $\begin{array}{c}-0.073^{* * * *} \\
(0.025)\end{array}$ & $\begin{array}{l}-0.018 \\
(0.029)\end{array}$ \\
\hline Share of CNG buses & & $\begin{array}{c}-0.061 \\
(0.065)\end{array}$ & $\begin{array}{c}-0.180^{*} \\
(0.080)\end{array}$ \\
\hline Share of hybrid buses & & $\begin{array}{c}-0.461^{* * * *} \\
(0.122)\end{array}$ & $\begin{array}{c}-0.594^{*} \\
(0.281)\end{array}$ \\
\hline Year \& State FE & $\mathrm{Y}$ & $\mathrm{Y}$ & $\mathrm{Y}$ \\
\hline Observations & 3706 & 3706 & 1444 \\
\hline$R^{2}$ & 0.216 & 0.283 & 0.386 \\
\hline F-Statistic for excluded IV & 7.28 & 8.21 & 2.76 \\
\hline
\end{tabular}

Note: The dependent variable is privatization share. (3) uses only observations in the RD analysis, thus agencies in (3) are dominant. (d) denotes a binary variable. Standard errors are clustered at the UZA level. ${ }^{*} p$ $<0.10,{ }^{* *} p<0.05,{ }^{* * *} p<0.01$.

${ }^{1}$ Omitted category is weak bargaining rights state.

${ }^{2}$ Omitted category is non-dominant transit agency.

${ }^{3}$ Omitted agency-type category is "Other", which includes state DOT or subsidiary agencies. 
APPENDIX TABLE 2B: Transit Agency Labor Cost Per Mile Estimates: IV Approach

\begin{tabular}{lccccc}
\hline & $(1)$ & $(2)$ & $(3)$ & $(4)$ & $(5)$ \\
& OLS & OLS & GMM & GMM & GMM \\
\hline Privatization share & $-0.309^{* * *}$ & $-0.226^{* * *}$ & $-0.457^{* *}$ & $-0.900^{* * *}$ & $-1.254^{*}$ \\
& $(0.059)$ & $(0.050)$ & $(0.217)$ & $(0.232)$ & $(0.652)$ \\
Year \& State FE & $\mathrm{Y}$ & $\mathrm{Y}$ & $\mathrm{Y}$ & $\mathrm{Y}$ & $\mathrm{Y}$ \\
UZA \& Agency Controls & & $\mathrm{Y}$ & & $\mathrm{Y}$ & $\mathrm{Y}$ \\
& & & & 3706 & 1444 \\
Observations $^{2}$ & 3706 & 3706 & 3706 & 0.249 & 0.277 \\
$R^{2}$ & 0.441 & 0.615 & 0.229 & $60.4 \%$ & $76.9 \%$ \\
\hline
\end{tabular}

Note: The dependent variable is log(labor and material costs per VMT). Columns (3)-(5) estimated using GMM with the IV being the Bartik IV *UZA Home price. (5) uses only observations in the RD analysis, thus agencies in (5) are dominant. UZA \& Agency Controls listed in Table 4. Standard errors are clustered at the UZA level. ${ }^{*} p<0.10,{ }^{* *} p<$ $0.05,{ }^{* * *} p<0.01$.

*Because equation (7) takes the semi-logarithmic functional form and the privatization rate ranges from 0 to 1 , a consistent estimator for the percentage impact from full privatization (e.g., privatization going from 0 to 1 ) on the labor $\operatorname{cost}$ is $\left[\exp \left(\hat{\gamma}-\frac{\operatorname{var}(\hat{\gamma})}{2}\right)-1\right]$. The values in the final row represent the expected cost reduction from an agency going from $0 \%$ privatized operations to $100 \%$. 
APPENDIX TABLE 3: Effect of Privatization on No. of Accidents

\begin{tabular}{|c|c|c|c|c|}
\hline & $\begin{array}{c}\text { (1) } \\
\text { NBReg } \\
\text { (Full Sample) }\end{array}$ & $\begin{array}{c}(2) \\
\text { NBReg } \\
\text { (RD Sample) }\end{array}$ & $\begin{array}{c}(3) \\
\text { NBReg IV }\end{array}$ & $\begin{array}{c}(4) \\
\text { NBReg FRD }\end{array}$ \\
\hline Privatization share & $\begin{array}{l}-0.262 \\
(0.176)\end{array}$ & $\begin{array}{l}-0.507 \\
(0.379)\end{array}$ & $\begin{array}{c}1.012 \\
(1.598)\end{array}$ & $\begin{array}{l}-2.852 \\
(4.123)\end{array}$ \\
\hline Ln(Total VMT) & $\begin{array}{l}1.479^{* * *} \\
(0.245)\end{array}$ & $\begin{array}{l}1.714^{* * *} \\
(0.415)\end{array}$ & $\begin{array}{l}1.343^{* * *} \\
(0.291)\end{array}$ & $\begin{array}{l}1.504^{* * *} \\
(0.553)\end{array}$ \\
\hline Hourly wage (low skill) & $\begin{array}{l}1.162^{* *} \\
(0.451)\end{array}$ & $\begin{array}{l}1.130^{*} \\
(0.645)\end{array}$ & $\begin{array}{l}0.898^{*} \\
(0.533)\end{array}$ & $\begin{array}{c}1.281 \\
(0.903)\end{array}$ \\
\hline Road congestion index & $\begin{array}{l}0.883^{*} \\
(0.462)\end{array}$ & $\begin{array}{c}0.988 \\
(0.763)\end{array}$ & $\begin{array}{l}1.386^{*} \\
(0.716)\end{array}$ & $\begin{array}{c}0.048 \\
(1.626)\end{array}$ \\
\hline House Price & $\begin{array}{l}-0.066^{*} \\
(0.038)\end{array}$ & $\begin{array}{l}-0.095 \\
(0.080)\end{array}$ & $\begin{array}{l}-0.065^{*} \\
(0.038)\end{array}$ & $\begin{array}{l}-0.134 \\
(0.116)\end{array}$ \\
\hline Union share ${ }^{*}$ StrongBarg $(d)^{1}$ & $\begin{array}{c}1.370 \\
(1.646)\end{array}$ & $\begin{array}{c}1.122 \\
(2.539)\end{array}$ & $\begin{array}{c}0.691 \\
(1.874)\end{array}$ & $\begin{array}{c}0.701 \\
(0.677)\end{array}$ \\
\hline Ln(population density) & $\begin{array}{c}0.005 \\
(0.298)\end{array}$ & $\begin{array}{l}-0.001 \\
(0.507)\end{array}$ & $\begin{array}{l}-0.127 \\
(0.349)\end{array}$ & $\begin{array}{c}0.595 \\
(1.159)\end{array}$ \\
\hline Dominant TA $(d)^{2}$ & $\begin{array}{c}0.242 \\
(0.218)\end{array}$ & & $\begin{array}{c}0.430 \\
(0.292)\end{array}$ & \\
\hline Independent agency $(d)^{3}$ & $\begin{array}{l}-0.509^{* *} \\
(0.211)\end{array}$ & $\begin{array}{l}-0.614^{*} \\
(0.346)\end{array}$ & $\begin{array}{l}-0.539^{* *} \\
(0.213)\end{array}$ & $\begin{array}{l}-0.479 \\
(0.396)\end{array}$ \\
\hline City agency $(d)^{3}$ & $\begin{array}{l}-0.513^{* *} \\
(0.233)\end{array}$ & $\begin{array}{l}-0.707^{*} \\
(0.385)\end{array}$ & $\begin{array}{l}-0.568^{* *} \\
(0.245)\end{array}$ & $\begin{array}{l}-0.543 \\
(0.437)\end{array}$ \\
\hline Ln(number of buses) & $\begin{array}{l}-0.204 \\
(0.262)\end{array}$ & $\begin{array}{l}-0.465 \\
(0.451)\end{array}$ & $\begin{array}{l}-0.065 \\
(0.314)\end{array}$ & $\begin{array}{l}-0.290 \\
(0.531)\end{array}$ \\
\hline Ln(average bus age) & $\begin{array}{l}-0.113 \\
(0.122)\end{array}$ & $\begin{array}{c}-0.239 \\
(0.173)\end{array}$ & $\begin{array}{l}-0.034 \\
(0.163)\end{array}$ & $\begin{array}{l}-0.279 \\
(0.206)\end{array}$ \\
\hline Share of CNG buses & $\begin{array}{c}-0.720^{* * *} \\
(0.251)\end{array}$ & $\begin{array}{l}-1.051^{* *} \\
(0.532)\end{array}$ & $\begin{array}{l}-0.638^{* *} \\
(0.273)\end{array}$ & $\begin{array}{l}-1.471 \\
(0.976)\end{array}$ \\
\hline Share of hybrid buses & $\begin{array}{l}-1.080^{*} \\
(0.635)\end{array}$ & $\begin{array}{l}-0.647 \\
(1.005)\end{array}$ & $\begin{array}{l}-0.479 \\
(0.905)\end{array}$ & $\begin{array}{l}-2.105 \\
(2.789)\end{array}$ \\
\hline Year \& State FE & $\mathrm{Y}$ & $\mathrm{Y}$ & $\mathrm{Y}$ & $\mathrm{Y}$ \\
\hline $\begin{array}{l}\text { Observations } \\
\text { AIC }\end{array}$ & $\begin{array}{c}2597 \\
13952.129\end{array}$ & $\begin{array}{r}1030 \\
6799.575\end{array}$ & $\begin{array}{c}2597 \\
13955.070\end{array}$ & $\begin{array}{r}1030 \\
6810.291\end{array}$ \\
\hline $\begin{array}{l}\text { Note: The dependent variable is the } \\
\text { denotes a binary variable. The IV in } \\
\text { specification in (4) uses both the den } \\
\text { bargaining rights indicator in the firs } \\
\text { margin and their interactions with de } \\
\text { parentheses. }{ }^{*} p<0.10,{ }^{* *} p<0.05,{ }^{* *} \\
{ }^{1} \text { Omitted category is weak bargainir } \\
{ }^{2} \text { Omitted category is non-dominant } \\
{ }^{3} \text { Omitted agency-type category is "O } \\
{ }^{*} \text { The sample sizes differ from those } \\
\text { on reported accidents. Our main resu }\end{array}$ & $\begin{array}{l}\text { lumber of annual n } \\
\text { specification (3) is } \\
\text { ocrat mayor assign } \\
\text { stage, and further } \\
\text { mocratic mayor du } \\
p<0.01 \text {. } \\
\text { g rights state. } \\
\text { ransit agency. } \\
\text { ther", which includ }\end{array}$ & $\begin{array}{l}\text { n-fatal and fatal in } \\
\text { he Bartik IV * UZ } \\
\text { nent variable as w } \\
\text { ontrols for the cub } \\
\text { my. Standard erro }\end{array}$ & $\begin{array}{l}\text { idents reported } \\
\text { average housi } \\
\text { l as its interacti } \\
\text { c polynomials o } \\
\text { s clustered at th }\end{array}$ & $\begin{array}{l}\text { he transit agency. ( } \\
\text { rices. The fuzzy RI } \\
\text { with state strong } \\
\text { mocratic winning } \\
\text { ZA level in } \\
\\
\text { CD data limitations } \\
\text { cies. }\end{array}$ \\
\hline
\end{tabular}




\section{APPENDIX TABLE 4: Effect of Privatization on Total VMT and Ridership}

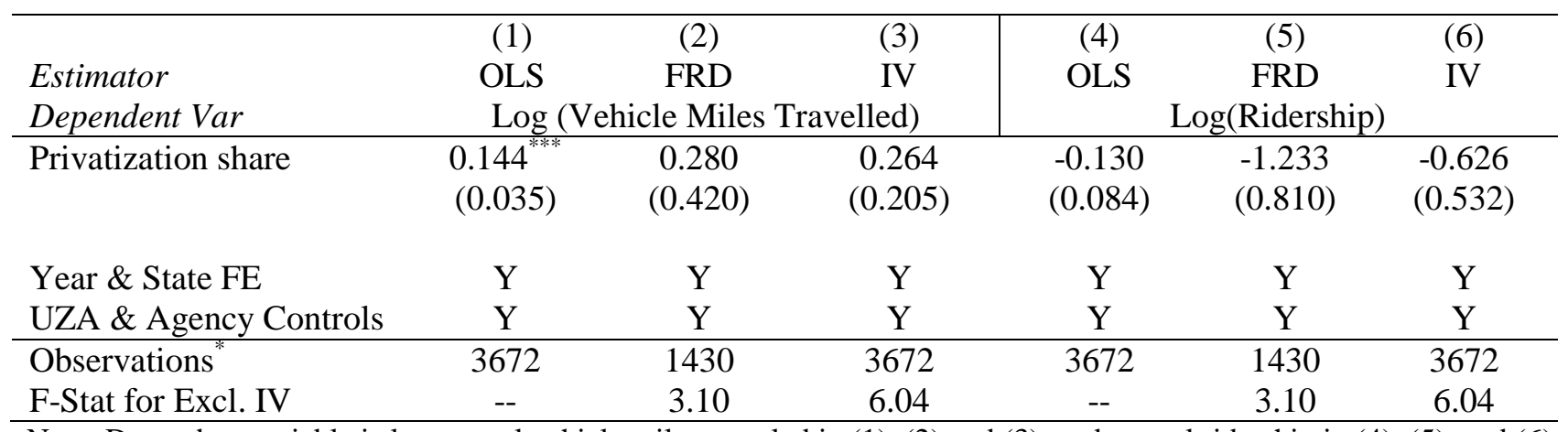

Note: Dependent variable is log annual vehicle miles traveled in (1), (2) and (3), and annual ridership in (4), (5), and (6). Ridership is annual passenger miles divided by annual vehicle miles. All regressions include controls for log(fleet size) and $\log$ (average fleet age) as of 1997 to control for initial service demand conditions. The fuzzy RD specifications further control for quadratic polynomials of democratic winning margin and their interactions with democratic mayor dummy, and use both the democrat mayor assignment variable as well as its interaction with strong state bargaining rights indicator in the first stage. The fuzzy RD estimates are based on dominant agencies only. The IV in specifications (3) and (6) is the Bartik IV * UZA average housing prices. UZA \& Agency Controls listed in Table 4. Standard errors are clustered at the UZA level. ${ }^{*} p<0.10,{ }^{* *} p<$ $0.05,{ }^{* * *} p<0.01$.

*The sample sizes differ from those employed in the main fuzzy RD and IV analyses due to NTD data limitations on passenger miles traveled. Our main results do not change when we remove these agencies. 
APPENDIX TABLE 5A: First Stage Regressions Using Contract Cycle as IV

\begin{tabular}{lcc}
\hline & $(1)$ & $(2)$ \\
& OLS & OLS \\
\hline Labor contract cycle & $0.016^{* * *}$ & $0.042^{* * *}$ \\
Hourly wage (low skill) & $(0.005)$ & $(0.005)$ \\
Road congestion index & -0.009 & -0.067 \\
& $(0.032)$ & $(0.084)$ \\
House Price & 0.014 & 0.103 \\
& $(0.111)$ & $(0.134)$ \\
Union share*StrongBarg $(d)^{1}$ & -0.001 & -0.004 \\
Ln(population density) & $(0.004)$ & $(0.006)$ \\
Ln(number of buses) & -0.100 & 0.217 \\
Ln(average bus age) & $(0.178)$ & $(0.357)$ \\
Share of CNG buses & $1.051^{* * *}$ & $1.225^{* * *}$ \\
Share of hybrid buses & $(0.401)$ & $(0.163)$ \\
Year FE & $0.173^{* * *}$ & $0.277^{* * *}$ \\
Agency FE & $(0.062)$ & $(0.040)$ \\
\hline Observations & $-0.036^{* *}$ & $-0.085^{* * *}$ \\
Adjusted $R^{2}$ & $(0.014)$ & $(0.020)$ \\
\hline & -0.011 & 0.049 \\
& $(0.043)$ & $(0.050)$ \\
& $-0.255^{* * *}$ & -0.237 \\
& $(0.082)$ & $(0.333)$ \\
& & $\mathrm{Y}$ \\
& & 130 \\
\hline
\end{tabular}

Note: The dependent variable is privatization share. The data include 10 transit agencies for which we have union contract cycle data. Column (1) is estimated after first-differencing (FD) while column (2) uses transit agency fixed effects (FE). Contract cycle variable is defined as the number of labor contract cycles since 1998. (d) denotes a binary variable. ${ }^{*} p$ $<0.10,{ }^{* *} p<0.05,{ }^{* * *} p<0.01$.

${ }^{1}$ Omitted category is weak bargaining rights state. 
APPENDIX TABLE 5B: Labor Cost Regression Using Contract Cycles as IV

\begin{tabular}{|c|c|c|c|c|}
\hline & $\begin{array}{c}(1) \\
\text { OLS w/ FD }\end{array}$ & $\begin{array}{c}(2) \\
\text { OLS w/ FE }\end{array}$ & $\begin{array}{c}(3) \\
\text { GMM w/FD }\end{array}$ & $\begin{array}{c}(4) \\
\text { GMM w/ FE }\end{array}$ \\
\hline Privatization share & $\begin{array}{c}-0.646^{* * *} \\
(0.129)\end{array}$ & $\begin{array}{c}-0.762^{\text {*** }} \\
(0.072)\end{array}$ & $\begin{array}{l}-0.389 \\
(0.598)\end{array}$ & $\begin{array}{c}-0.869^{* * *} \\
(0.141)\end{array}$ \\
\hline Hourly wage (low skill) & $\begin{array}{l}-0.103 \\
(0.093)\end{array}$ & $\begin{array}{c}0.020 \\
(0.116)\end{array}$ & $\begin{array}{l}-0.099 \\
(0.098)\end{array}$ & $\begin{array}{c}0.008 \\
(0.115)\end{array}$ \\
\hline Road congestion index & $\begin{array}{l}0.449^{*} \\
(0.267)\end{array}$ & $\begin{array}{l}0.429^{* * *} \\
(0.139)\end{array}$ & $\begin{array}{l}0.458^{*} \\
(0.273)\end{array}$ & $\begin{array}{l}0.418^{* * *} \\
(0.136)\end{array}$ \\
\hline House Price & $\begin{array}{l}0.014^{* *} \\
(0.007)\end{array}$ & $\begin{array}{c}0.003 \\
(0.006)\end{array}$ & $\begin{array}{l}0.014^{* *} \\
(0.007)\end{array}$ & $\begin{array}{c}0.004 \\
(0.006)\end{array}$ \\
\hline Union share*StrongBarg $(d)^{1}$ & $\begin{array}{c}0.065 \\
(0.292)\end{array}$ & $\begin{array}{l}-0.158 \\
(0.434)\end{array}$ & $\begin{array}{c}0.092 \\
(0.296)\end{array}$ & $\begin{array}{l}-0.120 \\
(0.428)\end{array}$ \\
\hline Ln(population density) & $\begin{array}{c}0.228 \\
(0.296)\end{array}$ & $\begin{array}{l}0.587^{* \text { *** }} \\
(0.145)\end{array}$ & $\begin{array}{l}-0.033 \\
(0.698)\end{array}$ & $\begin{array}{l}0.641^{\text {*** }} \\
(0.151)\end{array}$ \\
\hline Ln(population) & $\begin{array}{l}0.190^{* * *} \\
(0.057)\end{array}$ & $\begin{array}{l}0.160^{* *} \\
(0.068)\end{array}$ & $\begin{array}{c}0.143 \\
(0.099)\end{array}$ & $\begin{array}{l}0.203^{* *} \\
(0.081)\end{array}$ \\
\hline Ln(number of buses) & $\begin{array}{c}0.021 \\
(0.031)\end{array}$ & $\begin{array}{l}0.050^{* * * *} \\
(0.019)\end{array}$ & $\begin{array}{c}0.030 \\
(0.041)\end{array}$ & $\begin{array}{l}0.045^{* *} \\
(0.019)\end{array}$ \\
\hline Ln(average bus age) & $\begin{array}{c}0.009 \\
(0.084)\end{array}$ & $\begin{array}{c}0.059 \\
(0.052)\end{array}$ & $\begin{array}{c}0.014 \\
(0.085)\end{array}$ & $\begin{array}{c}0.056 \\
(0.052)\end{array}$ \\
\hline Share of CNG buses & $\begin{array}{c}-0.893^{* * *} \\
(0.305)\end{array}$ & $\begin{array}{c}-0.645^{* * *} \\
(0.207)\end{array}$ & $\begin{array}{c}-0.840^{* * *} \\
(0.302)\end{array}$ & $\begin{array}{c}-0.733^{* * *} \\
(0.216)\end{array}$ \\
\hline Share of hybrid buses & $\begin{array}{c}-0.646^{* * *} \\
(0.129)\end{array}$ & $\begin{array}{c}-0.762^{* * *} \\
(0.072)\end{array}$ & $\begin{array}{l}-0.389 \\
(0.598)\end{array}$ & $\begin{array}{c}-0.869^{* * *} \\
(0.141)\end{array}$ \\
\hline $\begin{array}{l}\text { Year FE } \\
\text { Agency FE }\end{array}$ & $\mathrm{Y}$ & $\begin{array}{l}\mathrm{Y} \\
\mathrm{Y}\end{array}$ & $\mathrm{Y}$ & $\begin{array}{l}\mathrm{Y} \\
\mathrm{Y}\end{array}$ \\
\hline F-Stat for Excl. IV & -- & -- & 7.22 & 59.79 \\
\hline Observations & 130 & 140 & 130 & 140 \\
\hline Adjusted $R^{2}$ & 0.144 & 0.933 & 0.137 & 0.932 \\
\hline
\end{tabular}

Note: The dependent variable is $\log ($ labor and material cost per VMT). The data include 10 transit agencies for which we have union contract cycle data. Columns (1) and (3) are estimated after first-differencing (FD) and columns (2) and (4) include transit agency fixed effects (FE). The IV for privatization is the number of labor contract cycles since 1998. (d) denotes a binary variable. ${ }^{*} p<0.10,{ }^{* *} p<0.05,{ }^{* * *} p<0.01$.

${ }^{1}$ Omitted category is weak bargaining rights state. 
APpendiX TABLE 6: Effect of Privatization on Bus Costs per Mile Using Subway as Control

\begin{tabular}{|c|c|c|}
\hline $\begin{array}{l}\text { Estimator } \\
\text { Dependent Var }\end{array}$ & $\begin{array}{c}\text { (1) } \\
\text { OLS } \\
\log (\text { Bus cost per VMT) }\end{array}$ & $\begin{array}{c}\text { (2) } \\
\text { OLS } \\
\log (\text { Bus cost/Subway cost) }\end{array}$ \\
\hline Privatization share & $\begin{array}{c}-1.008^{* * *} \\
(0.115)\end{array}$ & $\begin{array}{c}-1.002^{* * *} \\
(0.226)\end{array}$ \\
\hline Log(total cost per mile for subway) & $\begin{array}{l}0.248^{* * *} \\
(0.044)\end{array}$ & \\
\hline Hourly wage (low skill) & $\begin{array}{c}0.183 \\
(0.185)\end{array}$ & $\begin{array}{c}0.117 \\
(0.236)\end{array}$ \\
\hline Ln(Nat. Gas price) & $\begin{array}{c}0.017 \\
(0.014)\end{array}$ & $\begin{array}{l}-0.016 \\
(0.027)\end{array}$ \\
\hline Ln(Diesel price) & $\begin{array}{l}-0.326 \\
(0.282)\end{array}$ & $\begin{array}{l}-1.529^{* *} \\
(0.558)\end{array}$ \\
\hline Road congestion index & $\begin{array}{c}0.093 \\
(0.202)\end{array}$ & $\begin{array}{c}0.049 \\
(0.296)\end{array}$ \\
\hline House Price & $\begin{array}{c}0.012 \\
(0.015)\end{array}$ & $\begin{array}{c}0.052 \\
(0.030)\end{array}$ \\
\hline Union share*StrongBarg $(d)^{1}$ & $\begin{array}{l}-0.118 \\
(0.579)\end{array}$ & $\begin{array}{c}0.925 \\
(0.900)\end{array}$ \\
\hline Ln(population density) & $\begin{array}{c}0.244 \\
(0.302)\end{array}$ & $\begin{array}{l}-0.462 \\
(0.365)\end{array}$ \\
\hline Independent agency $(d)^{2}$ & $\begin{array}{l}-0.223 \\
(0.218)\end{array}$ & $\begin{array}{l}-0.803^{* * *} \\
(0.179)\end{array}$ \\
\hline City agency $(d)^{2}$ & $\begin{array}{l}-0.753^{* * *} \\
(0.136)\end{array}$ & $\begin{array}{l}-0.745^{* *} \\
(0.238)\end{array}$ \\
\hline Ln(number of buses) & $\begin{array}{c}0.024 \\
(0.048)\end{array}$ & $\begin{array}{c}0.087 \\
(0.073)\end{array}$ \\
\hline Log(average bus age) & $\begin{array}{c}0.001 \\
(0.065)\end{array}$ & $\begin{array}{l}-0.176 \\
(0.099)\end{array}$ \\
\hline Share of CNG buses & $\begin{array}{l}-0.254^{* * *} \\
(0.070)\end{array}$ & $\begin{array}{l}-0.236^{*} \\
(0.122)\end{array}$ \\
\hline Share of hybrid buses & $\begin{array}{l}-0.191 \\
(0.179)\end{array}$ & $\begin{array}{l}-0.550 \\
(0.395)\end{array}$ \\
\hline Year \& State FE & $\mathrm{Y}$ & $\mathrm{Y}$ \\
\hline $\begin{array}{l}\text { Observations } \\
R^{2}\end{array}$ & $\begin{array}{c}140 \\
0.977\end{array}$ & $\begin{array}{c}140 \\
0.953\end{array}$ \\
\hline
\end{tabular}

Note: The dependent variable in (1) is log(total bus operating cost per VMT). The dependent variable in (2) is $\log$ (total bus operating cost per VMT / total subway operating cost per subway mile traveled). Total operating costs include labor and material costs, fuel costs, administration, and maintenance. (d) denotes a binary variable. The data include 10 transit agencies that run both a bus system and a subway system. Standard errors are clustered at the transit agency level. ${ }^{*} p<0.10,{ }^{* *} p<0.05,{ }^{* * *} p<0.01$.

${ }^{1}$ Omitted category is weak bargaining rights state.

${ }^{2}$ Omitted agency-type category is "Other”, which includes state DOT or subsidiary agencies. 
APPENDIX Table 7: Heterogeneous Treatment Effects of Privatization on Labor Costs per VMT

\begin{tabular}{lcc}
\hline & $(1)$ & $(2)$ \\
& OLS & GMM \\
\hline Privatization share & $0.596^{* * * *}$ & 1.866 \\
& $(0.206)$ & $(1.299)$ \\
Privatization*StrongBarg $(d)^{1}$ & $-0.463^{* * *}$ & $-1.320^{* *}$ \\
& $(0.104)$ & $(0.659)$ \\
Privatization share*transit size & $-0.134^{* * *}$ & $-0.336^{*}$ \\
& $(0.042)$ & $(0.199)$ \\
Year \& State FE & $\mathrm{Y}$ & $\mathrm{Y}$ \\
UZA \& Agency Controls & $\mathrm{Y}$ & $\mathrm{Y}$ \\
\hline F State for Excl. IV & & 10.95 \\
$R^{2}$ & 0.637 & 0.420 \\
Observations & 3706 & 3706 \\
\hline
\end{tabular}

Note: The dependent variable is $\log ($ labor and material cost per VMT). Transit size is measured with $\log ($ fleet size). The IV for privatization share is the Bartik IV * UZA average house prices. The IV for privatization share*StrongBarg is Bartik IV*UZA average house prices interacted with strong collective bargaining indicator. The IV for privatization share*transit size is the Bartik IV*UZA average house price interacted with transit size. $(d)$ denotes a binary variable. UZA \& Agency Controls listed in Table 4.

Standard errors are clustered at the UZA level. ${ }^{*} p<0.10,{ }^{* *} p<0.05,{ }^{* * *} p<0.01$.

${ }^{1}$ Omitted category is weak bargaining rights state. 
APPENDIX TABLE 8: TRANSIT AgENCY ENERGY COST PER VMT ESTIMATES: REGRESSION DISCONTINIUTY APPROACH

\begin{tabular}{|c|c|c|c|c|c|c|c|}
\hline & $\begin{array}{l}(1) \\
\text { OLS }\end{array}$ & $\begin{array}{l}(2) \\
\text { OLS }\end{array}$ & $\begin{array}{c}(3) \\
\text { GMM }\end{array}$ & $\begin{array}{c}(4) \\
\text { GMM }\end{array}$ & $\begin{array}{c}(5) \\
\text { GMM }\end{array}$ & $\begin{array}{c}(6) \\
\text { GMM }\end{array}$ & $\begin{array}{c}\text { (7) } \\
\text { LPoly }\end{array}$ \\
\hline Privatization share & $\begin{array}{l}-0.152 \\
(0.105)\end{array}$ & $\begin{array}{l}-0.210^{* *} \\
(0.080)\end{array}$ & $\begin{array}{l}-2.035 \\
(1.420)\end{array}$ & $\begin{array}{l}-1.019 \\
(1.065)\end{array}$ & $\begin{array}{l}-1.315^{*} \\
(0.719)\end{array}$ & $\begin{array}{l}-0.874 \\
(0.609)\end{array}$ & $\begin{array}{l}-2.039 \\
(1.325)\end{array}$ \\
\hline Ln(Nat. Gas price) & & $\begin{array}{l}0.053^{*} \\
(0.028)\end{array}$ & & $\begin{array}{c}0.082 \\
(0.053)\end{array}$ & & $\begin{array}{l}0.076^{* * *} \\
(0.038)\end{array}$ & \\
\hline Ln(Diesel price) & & $\begin{array}{l}1.179^{* * *} \\
(0.444)\end{array}$ & & $\begin{array}{l}-0.063 \\
(1.692)\end{array}$ & & $\begin{array}{l}0.150 \\
(1.072)\end{array}$ & \\
\hline Road congestion index & & $\begin{array}{l}-0.209 \\
(0.138)\end{array}$ & & $\begin{array}{l}-0.459 \\
(0.352)\end{array}$ & & $\begin{array}{l}-0.416^{*} \\
(0.224)\end{array}$ & \\
\hline House Price & & $\begin{array}{l}-0.019 \\
(0.012)\end{array}$ & & $\begin{array}{l}-0.028 \\
(0.020)\end{array}$ & & $\begin{array}{l}-0.027 \\
(0.017)\end{array}$ & \\
\hline Union share*StrongBarg $(d)^{1}$ & & $\begin{array}{l}-0.494 \\
(0.363)\end{array}$ & & $\begin{array}{c}0.191 \\
(0.959)\end{array}$ & & $\begin{array}{l}0.070 \\
(0.619)\end{array}$ & \\
\hline Ln(population density) & & $\begin{array}{c}0.057 \\
(0.075)\end{array}$ & & $\begin{array}{c}0.208 \\
(0.200)\end{array}$ & & $\begin{array}{c}0.185 \\
(0.136)\end{array}$ & \\
\hline Independent agency $(d)^{2}$ & & $\begin{array}{l}-0.170^{* * *} \\
(0.062)\end{array}$ & & $\begin{array}{l}-0.112 \\
(0.132)\end{array}$ & & $\begin{array}{l}-0.122 \\
(0.106)\end{array}$ & \\
\hline City agency $(d)^{2}$ & & $\begin{array}{l}-0.139^{* *} \\
(0.067)\end{array}$ & & $\begin{array}{l}-0.087 \\
(0.137)\end{array}$ & & $\begin{array}{l}-0.095 \\
(0.114)\end{array}$ & \\
\hline Ln(number of buses) & & $\begin{array}{l}0.079^{* * *} \\
(0.018)\end{array}$ & & $\begin{array}{l}0.068^{* * *} \\
(0.024)\end{array}$ & & $\begin{array}{l}0.069^{* * *} \\
(0.022)\end{array}$ & \\
\hline Ln(average bus age) & & $\begin{array}{l}0.148^{* * *} \\
(0.037)\end{array}$ & & $\begin{array}{l}0.143^{* * *} \\
(0.041)\end{array}$ & & $\begin{array}{l}0.142^{* * *} \\
(0.039)\end{array}$ & \\
\hline Share of CNG buses & & $\begin{array}{l}-0.568^{* * * *} \\
(0.076)\end{array}$ & & $\begin{array}{l}-0.702^{* * * *} \\
(0.220)\end{array}$ & & $\begin{array}{l}-0.675^{* * * *} \\
(0.142)\end{array}$ & \\
\hline Share of hybrid buses & & $\begin{array}{l}-0.357 \\
(0.248)\end{array}$ & & $\begin{array}{l}-0.782 \\
(0.673)\end{array}$ & & $\begin{array}{l}-0.703 \\
(0.453)\end{array}$ & \\
\hline $\begin{array}{l}\text { Year \& State FE } \\
\text { Democrat } * \text { StrongBarg }\end{array}$ & $\mathrm{Y}$ & $\mathrm{Y}$ & $\mathrm{Y}$ & $\mathrm{Y}$ & $\begin{array}{l}\mathrm{Y} \\
\mathrm{Y}\end{array}$ & $\begin{array}{l}\mathrm{Y} \\
\mathrm{Y}\end{array}$ & \\
\hline $\begin{array}{l}\text { Robust CCT Confidence Interval } \\
\text { Observations } \\
R^{2}\end{array}$ & $\begin{array}{l}1427 \\
0.749\end{array}$ & $\begin{array}{l}1427 \\
0.841\end{array}$ & $\begin{array}{l}1427 \\
0.232\end{array}$ & $\begin{array}{l}1427 \\
0.750\end{array}$ & $\begin{array}{l}1427 \\
0.539\end{array}$ & $\begin{array}{l}1427 \\
0.775\end{array}$ & $\begin{array}{c}-5.118 ; 0.557] \\
503\end{array}$ \\
\hline
\end{tabular}

Note: The dependent variable is log(energy cost per VMT). Includes dominant transit agencies. $(d)$ denotes a binary variable. All regressions control for quadratic polynomial of winning margin and their interaction with democrat mayor indicator. "LPoly" employs local polynomial Fuzzy RD estimation with robust confidence intervals developed by Calonico, Cattaneo

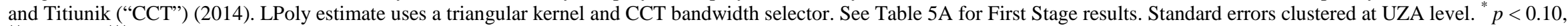
${ }^{* *} p<0.05,{ }^{* * *} p<0.01$

${ }^{1}$ Omitted category is weak bargaining rights state.

${ }^{2}$ Omitted agency-type category is "Other", which includes state DOT or subsidiary agencies.

*The sample sizes differ from the main fuzzy RD analyses due to NTD data limitations on energy inputs. Our main results do not change substantially when we remove these agencies. 